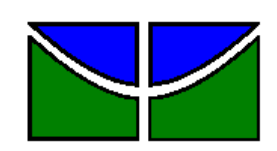

Universidade de Brasília

Faculdade de Economia, Administração e Contabilidade

Programa de Pós-Graduação em Economia

Mestrado Profissional em Economia

NEWTON DA SILVA MIRANDA JÚNIOR

\title{
ANÁLISE DE REDES SOCIAIS: um estudo acerca das mudanças de curso na UnB
}

Brasília - DF

2016 
NEWTON DA SILVA MIRANDA JÚNIOR

\section{ANÁLISE DE REDES SOCIAIS: um estudo acerca das mudanças de curso na UnB}

Dissertação apresentada ao Departamento de Economia da Universidade de Brasília como requisito parcial à obtenção do título de Mestre em Economia, área de concentração: Gestão Econômica de Finanças Públicas.

Orientadora: $\operatorname{Prof}^{\mathrm{a}} \mathrm{Dr}^{\mathrm{a}}$ Andrea Felippe Cabello

Brasília - DF

2016 
Ficha Catalográfica elaborada pela Biblioteca Central da Universidade de Brasília

\begin{tabular}{|c|c|}
\hline MM672a & $\begin{array}{l}\text { Miranda Júnior, Newton da Silva } \\
\text { Análise de redes sociais: um estudo acerca das } \\
\text { mudanças de curso na UnB / Newton da Silva Miranda } \\
\text { Júnior; orientador Andrea Felippe Cabello. -- } \\
\text { Brasilia, } 2016 \text {. } \\
\quad 101 \text { p. }\end{array}$ \\
\hline & $\begin{array}{l}\text { Dissertação (Mestrado - Mestrado Profissional em } \\
\text { Economia - Gestăo Econômica de Finanças Públicas) -- } \\
\text { Universidade de Brasilia, 2016. }\end{array}$ \\
\hline & $\begin{array}{l}\text { 1. Mudança de curso de graduação. 2. Análise de } \\
\text { Rede Social. 3. Transferência interna de alunos. } 4 . \\
\text { Mobilidade acadêmica. } 5 \text {. Evasão no ensino superior. } \\
\text { I. Felippe Cabello, Andrea, orient. II. Título. }\end{array}$ \\
\hline
\end{tabular}




\section{ANÁLISE DE REDES SOCIAIS: um estudo acerca das mudanças de curso na UnB}

Dissertação apresentada ao Departamento de Economia da Universidade de Brasília como requisito parcial à obtenção do título de Mestre em Economia, área de concentração: Gestão Econômica de Finanças Públicas.

Comissão Examinadora formada pelos professores:

Prof $\stackrel{a}{\text {. Dra }}$. Andrea Felippe Cabello

Professora-Orientadora

Prof ${ }^{a}$. Dra . Denise Imbroisi

Professora Examinadora
Prof ${ }^{a}$. Drª . Cláudia da Conceição Garcia Professora Examinadora

Brasília, 24 de janeiro de 2017 
Em memória de Daniel Alves Soares, meu eterno irmãozinho. O meu sinônimo de alegria, gentileza e companheirismo. Os palcos dessa dimensão não eram suficientes para o seu talento. Imensa gratidão por ter me ensinado a ser uma pessoa melhor, Por todo amor, zelo e carinho. Te amo. Para sempre. 
Não temas, tão-somente creia:

Deus, todo poderoso, reina! 


\section{AGRADECIMENTOS}

Aos meus amados pais Newton e Aparecida que, sendo as minhas bases, possibilitam-me estar estruturado para todos os desafios da vida. Em especial, minha mãe: meu braço direito em tudo na vida.

Ao Daniel, meu eterno lado bom da vida.

Ao Renan, nunca medindo esforços para me apoiar, graciosa e cuidadosamente, nos desafios da vida.

Aos meus irmãos, Keli e Keslley: leais companheiros.

À Prof ${ }^{a}$. Dr ${ }^{\mathrm{a}}$. Andrea Felippe Cabello, pela acolhida, orientações e ensinamentos.

À Isabela Ferraz, quem me serviu de inspiração para prosseguir nos estudos acadêmicos, sempre compartilhando conhecimentos e direcionamentos. À Luciana Couto, por ter tornado a jornada de mestrado descontraída e prazerosa.

Aos membros da banca, Prof ${ }^{a}$ Dr $^{a}$. Cláudia Garcia e Prof ${ }^{a}$. Dr ${ }^{a}$. Denise Imbroisi, pelas oportunas observações e considerações do trabalho.

À Joana Farias, pela presteza, eficiência e humanidade no atendimento dos alunos do programa de mestrado em Gestão Econômica de Finanças Públicas. 


\section{RESUMO}

O presente estudo buscou descrever como são estabelecidas as transferências internas de alunos entre as mudanças de curso de graduação na Universidade de Brasília e seus reflexos no fluxo de alunos entre os turnos e entre os campi dessa instituição. Foram analisadas as mudanças de curso ocorridas entre o primeiro período de 2012 ao primeiro período de 2016, as quais são regulamentadas por editais publicados semestralmente. No total, foram registradas 1.050 transferências internas de alunos por meio de mudanças de curso. Em complemento, buscou-se verificar como essas transferências internas ocorrem entre as áreas de conhecimento e se elas são caracterizadas pelo efeito trampolim, entendido como a saída de um curso menos concorrido para outro mais concorrido. A metodologia empregada foi a de análise de redes sociais. Os resultados encontrados revelaram que a rede de transferência interna é protagonizada por alguns cursos específicos, sendo que os cursos que mais registraram saída de alunos por meio da transferência interna foram: Letras - Português (diurno), Ciências Sociais e Engenharia (FGA). Os cursos que mais tiveram ingressos foram: Psicologia, Comunicação Social e Engenharia Mecânica. Com base nos resultados, infere-se que o estudante, apesar de indeciso quanto ao curso, possui como certa a área de estudo que pretende seguir. Mesmo não existindo regras nos editais que limitem a mudança de curso dentro de áreas afins, as interações entre os cursos ocorrem no âmbito das grandes áreas de conhecimento, sobremodo entre os cursos de Exatas e Engenharias. Ademais, foi possível se verificar um movimento de saída de cursos menos concorridos para cursos mais concorridos. Mesmo diante indícios de que as mudanças de cursos ocorrem sob influência do efeito trampolim, ainda assim, as transferências internas ocorrem entre cursos pertencentes a mesma grande área de conhecimento.

Palavras-chave: Mudança de curso de graduação; Análise de Rede Social; Transferência interna de alunos; Evasão no ensino superior. 


\section{ABSTRACT}

The purpose of this study was to describe how the changes between undergraduate courses at the University of Brasilia take place and its impact on the migration of students between the shifts and between the campuses of this institution. We analyzed the course changes that occurred between the first semester of 2012 and the first semester of 2016. In total there were 1,050 internal transfers of students. Another purpose of the study was to verify how these internal transfers occur between the areas of knowledge and whether they are characterized by the opportunistic change of course, understood as the departure from a less crowded course to a more crowded one. The methodology used was the analysis of social networks. The results revealed that the internal transfer network is characterized by specific courses, and the ones that had the most evasion of students were: Letras Português, Ciências Sociais and the basic cycle in Engineering. The courses that had the most enrollments were: Psychology, Social Communication and Mechanical Engineering. Based on the results, it is inferred that despite the student's indecisiveness about the course, he holds the area of study he intends to follow. Even though there are no rules that limit the change of course within related areas, the interactions between the courses take place within the scope of the large areas of knowledge, especially between the Exact and Engineering courses. In addition, it was possible to notice abandonment of students in courses less demanded and registration in courses more demanded. Even though there are opportunistic changes in courses, they still occur among courses belonging to the same great area of knowledge.

Key words: Course change; Social Network Analysis; Internal transfer of students; Evasion in higher education. 


\section{LISTA DE FIGURAS}

Figura 1 Relação direcionada e não-direcionada entre vértices de uma rede ..........21

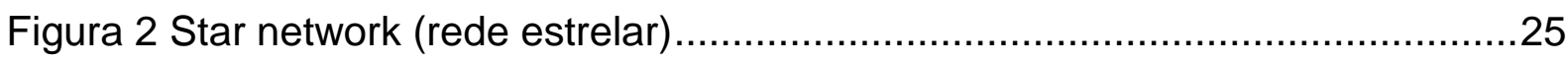

Figura 3 llustração de algoritmos aglomerativos (a) e divisivos (b) ..........................30

Figura 4 Rede transferência interna entre os turnos da UnB ..................................68

Figura 6 Rede de transferência interna entre os cursos da UnB.............................73

\section{LISTA DE GRÁFICOS}

Gráfico 1 Ordenação dos cursos por resultado líquido ........................................58

Gráfico 2 Vagas ofertadas nos editais e ingressos via transferências internas.........60

Gráfico 3 Distribuição do grau de saídas via transferências internas .......................62

Gráfico 4 Distribuição do grau de entradas via transferências internas ....................63

Gráfico 5 Pares ou conjuntos de cursos similares na rede de transferência interna.79

\section{LISTA DE TABELAS}

Tabela 1 Valores de ajustamento à quantidade de facções .....................................50

Tabela 2 Cursos que participaram da transferência interna ....................................52

Tabela 3 Resultados Líquidos das migrações entre cursos ...................................56

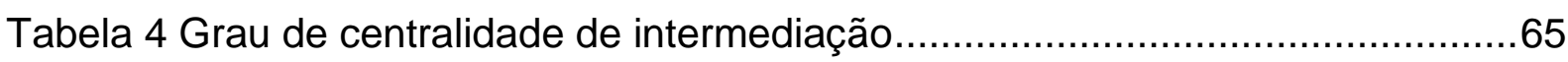

Tabela 5 Migração entre turnos via transferência interna na UnB.............................68

Tabela 7 Migração entre os campi via transferência interna na UnB .......................70

Tabela 8 Migrações entre pares ou conjuntos de cursos via transferência interna ...81

\section{LISTA DE QUADROS}

Quadro 1 Síntese dos motivos que influenciam a mudança de curso .........................38

Quadro 2 Ponderação utilizada na fórmula da mudança de curso ............................40

Quadro 3 Síntese das regras de mudança de curso em outras universidades .........43

Quadro 4 Objetivos específicos e metodologia de análise utilizada..........................45

Quadro 5 Classificação dos cursos nas áreas de conhecimentos adotadas.............46

Quadro 6 Classificação dos cursos sugerida pelo algoritmo utilizado ......................74

Quadro 7 Categorização dos cursos conforme demanda nos vestibulares da UnB..81 


\section{LISTA DE ABREVIATURAS E SIGLAS}

CEPE Conselho de Ensino, Pesquisa E Extensão

CPD Centro de Informática

FCE Faculdade de Ceilândia

FGA Faculdade do Gama

FUP Faculdade de Planaltina

IES Instituição de Ensino Superior

INEP Instituto Nacional De Estudos E Pesquisas Educacionais Anísio Teixeira

IRA Índice de Rendimento Acadêmico

MEC Ministério da Educação

SAA Secretaria de Administração Acadêmica

SiSU Sistema de Seleção Unificada

TCU Tribunal de Contas da União

UnB Universidade de Brasília 


\section{SUMÁRIO}

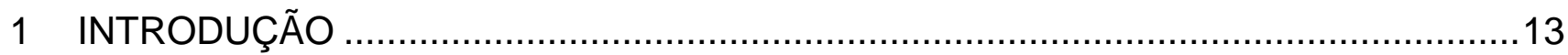

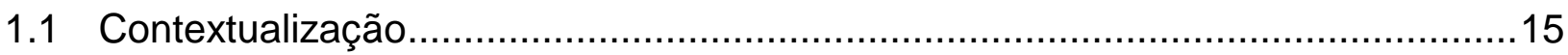

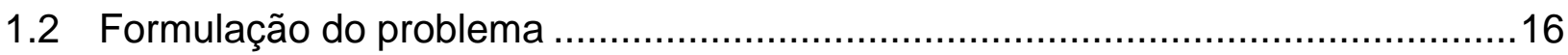

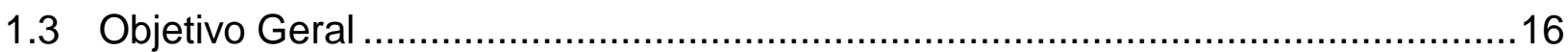

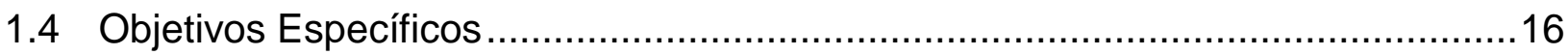

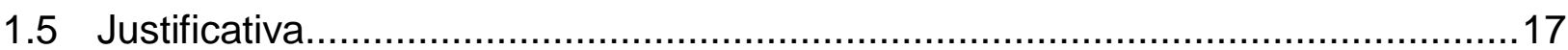

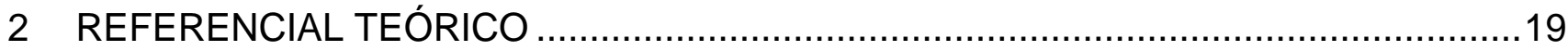

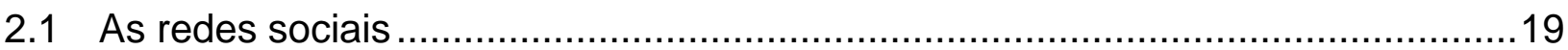

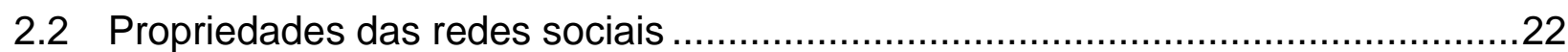

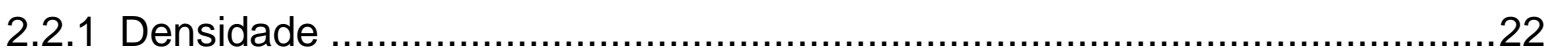

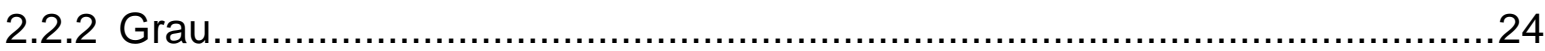

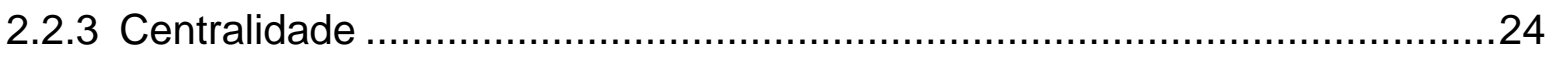

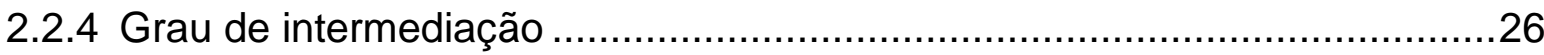

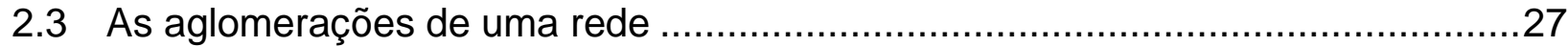

2.3.1 A análise de aglomerações ...........................................................29

2.4 As transferências internas de alunos: evasão? ........................................ 32

2.5 Motivos que influenciam a Mudança de Curso ...............................................34

2.6 As regras para a transferência interna de alunos nas IES ..............................38

2.6.1 A transferência interna de alunos na Universidade de Brasília ...................39

2.6.2 A transferência interna de alunos em outras universidades ......................41

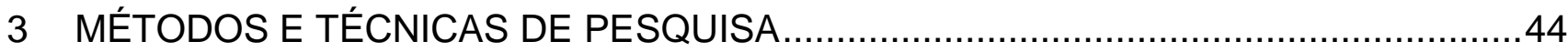

3.1 Tipo e Descrição Geral da Pesquisa .......................................................44

3.2 Definição Operacional dos Elementos da Rede de Transferência Interna ............45

3.3 Tipos e Coleta de Dados.................................................................. 46

3.4 Tratamento, análise e interpretação dos dados ........................................48

3.5 Análise Faccional para Identificação de Subgrupos......................................49

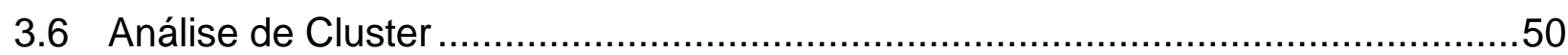


4 RESULTADOS E DISCUSSÃO

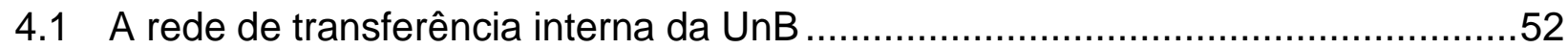

4.2 Propriedades da rede de transferência interna da UnB ....................................61

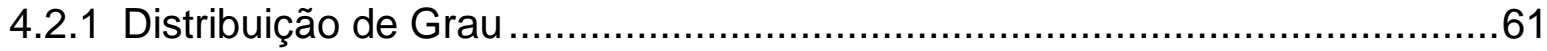

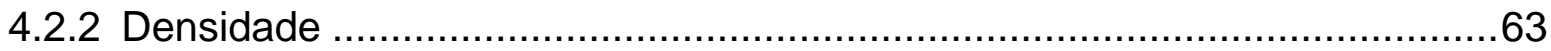

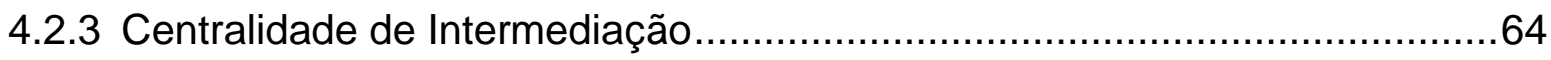

4.2.4 Fluxo entre os turnos via transferência interna de alunos ...........................66

4.2.5 Fluxo entre os campi via transferência interna de alunos............................69

4.3 As transferências internas de alunos entre as áreas de conhecimento .................71

4.4 As transferências internas de alunos e o efeito trampolim ...................................77

5 CONCLUSÕES

REFERÊNCIAS .89

Anexo A Categorização dos cursos conforme a concorrência nos exames vestibulares. 95

Anexo B Cursos de Destino a partir do Campus de Origem 97

Anexo C Quantidade de vagas ofertadas pelos cursos nos editais de transferência interna 100 


\section{INTRODUÇÃO}

A evasão no ensino superior tem sido abordada amplamente pela literatura desde o trabalho seminal de Tinto (1973). Embora os números que informam a evasão possam ser considerados expressivos, especialmente no Brasil, é válido salientar que nem toda evasão representa fuga do sistema de ensino superior. A evasão pode ser concebida em três não excludentes óticas: evasão de curso, evasão de instituição e evasão do sistema de ensino superior (BRASIL, 1997; LOBO, 2012).

A despeito disso, há metodologias de cálculo de evasão que consideram como deserção acadêmica, no sentido de saída do sistema como um todo, os dados relativos à mudança de curso, assim como os relativos à mudança de instituição de ensino superior (BRAGA; CARDEAL; PINTO, 1996; CUNHA; TUNES; SILVA, 2001; LOBO, 2012; GÓMEZ; TORRES, 2015). De modo geral, conforme sublinham Dias Sobrinho (1999), Velloso e Cardoso (2008), as abordagens da evasão no ensino superior não costumam distinguir esses casos.

A não distinção entre a saída do aluno de um curso em relação à saída de uma instituição ou do sistema como um todo ocasiona a superestimação do quantitativo de evasão do ensino superior. Não obstante, deixa-se de contribuir ao melhor entendimento de cada um desses casos por tratá-los como sinônimos. O aluno que abandona um curso, por exemplo, não necessariamente abandona a ideia da formação de nível superior (BAREFOOT, 2004; VELLOSO; CARDOSO, 2008). Possivelmente, ele o faz mas volta a se dedicar a outro curso de graduação (VRIES et al., 2011). Trata-se do que Velloso e Cardoso (2008) consideram por evasão aparente: a mudança de curso com permanência no ensino superior.

A mudança de curso pode ser entendida como a situação em que um estudante inicia uma outra graduação sem ter concluído a anterior (McMILLAN, 2005), podendo ser na mesma instituição de ensino ou não. De acordo com a definição dada pelo art. 1ํ da Resolução CEPE/UnB n. 138/2010: "é a autorização dada ao estudante regular de graduação para ter alterado o vínculo com seu curso de ingresso para outro curso de sua escolha". Neste estudo, a mudança de curso, 
também denominada como transferência interna de alunos, refere-se à migração entre cursos de origem para cursos de destino, por meio de editais, no âmbito da Universidade de Brasília - UnB.

Entre os argumentos favoráveis à mobilidade interna entre cursos, via mudança de curso, alega-se que se trata de uma maneira de readaptação do estudante ao sistema acadêmico (MAGALHÃES; REDIVO, 1998; SBARDELINI, 2001) e uma alternativa ao combate da evasão do ensino superior como um todo (SBARDELINI, 2001). No entanto, a possibilidade de mudança de curso pode suscitar práticas oportunistas entre os estudantes, a exemplo do ingresso intencional em determinado curso menos concorrido ou indesejado apenas como ponte de acesso ou trampolim ao curso realmente pretendido (BRASIL, 1997; CUNHA; TUNES; SILVA, 2001).

Para além das vantagens e desvantagens advindas das mudanças de curso, identificou-se a necessidade de se analisar e entender como elas ocorrem, em termos de transferências internas de alunos via editais. Em complemento aos estudos sobre a temática evasão, em específico a mudança de curso, esse estudo debruça-se sobre a descrição de como são estabelecidas as transferências internas de alunos entre os cursos de graduação na Universidade de Brasília e seus reflexos no fluxo entre os turnos e entre os campi dessa instituição de ensino superior.

Em adição, buscou-se verificar como essas mudanças de curso ocorrem entre as áreas de conhecimento e se são caracterizadas pelo efeito trampolim, o qual é entendido nesse estudo como a saída de um curso menos concorrido para outro mais demandado nos vestibulares da UnB. A fim de viabilizar o alcance dos objetivos propostos, utilizou-se a metodologia de análise de redes sociais.

Assim, este estudo se assenta na articulação de duas temáticas que até então, conforme varredura na literatura, estavam dissociadas: análise de redes sociais e evasão de curso superior. De acordo com Figueiredo (2011), por meio de redes é possível se observar como elementos ou indivíduos se interligam e quais são as decorrências disto, sendo que essa abordagem tem contribuído para estudos que tem interessado a ciências sociais desde o século passado (NEWMAN, 2004).

Em relação à estrutura do estudo, após essa introdução, é apresentada a revisão teórica acerca de redes sociais e suas principais propriedades. Em seguida, realiza-se uma discussão sobre a mudança de curso, destacando-se motivos que a 
influenciam. Por fim, descreve-se como tem sido o processo de transferência interna de alunos entre as mudanças de cursos na Universidade de Brasília, segundo os editais analisados.

\subsection{Contextualização}

A evasão não implica necessariamente em abandono do ensino superior, tampouco em abandono de uma instituição (SBARDELINI, 2001), conforme salientado anteriormente. Estudos recentes, a exemplo de Gómez e Torres (2015), têm demonstrado que parte do que se considera fuga do ensino superior refere-se, na verdade, à mudança de curso ou de campus. Como consequência disso, os índices que informam a evasão no ensino superior brasileiro tendem, naturalmente, a estar superestimados. Diante de tais índices expressivos, autores como Reis, Cunha e Spritzer (2012) recomendam estudos mais apurados acerca da deserção no ensino superior.

Nesse sentido, entre as variadas formas de evasão, destaca-se, nesse trabalho, a possibilidade de o estudante mudar de um curso para outro dentro de uma mesma instituição, no caso a Universidade de Brasília, configurando-se evasão do curso em si, mas não da instituição, tampouco do sistema de ensino superior (GÓMEZ, TORRES; 2015). Para melhor compreensão desse tipo de evasão, empregou-se a abordagem de análise de redes sociais. Tal abordagem desponta como um poderoso mecanismo que auxilia no entendimento de como elementos e indivíduos estão interligados na sociedade, sendo uma importante colaboração para as ciências sociais (FIGUEIREDO, 2011).

De modo geral, os acontecimentos que nos envolvem dificilmente podem ser entendidos isoladamente, desconectados um dos outros (FIGUEIREDO, 2011). Na abordagem de rede, a conexão entre objetos pode ter diversas significações. Tais relacionamentos podem representar, por exemplo, amizade ou namoro entre pessoas, citações entre trabalhos acadêmicos ou, ainda, negócios entre empresas (NEWMAN, 2004; FIGUEIREDO, 2011). No presente estudo, esses relacionamentos representam as mudanças entre cursos de graduação na Universidade de Brasília 
por meio de transferência interna, no período do primeiro semestre de 2012 ao primeiro semestre de 2016.

O problema de pesquisa em questão foi motivado, sobremodo, pela necessidade de se estudar como se dão os fluxos entre as mudanças de curso de graduação via transferência interna de alunos, buscando-se averiguar se as permutas entre cursos ocorrem dentro das mesmas áreas de conhecimento, se existe um movimento padronizado que caracterize ponte de acesso ou trampolim entre os cursos de graduação, no sentido de migração de cursos menos concorridos para os mais concorridos.

\subsection{Formulação do problema}

A partir do exposto, emergiu a seguinte pergunta de pesquisa norteadora desse estudo: Como ocorrem as mudanças de curso de graduação via transferência interna de alunos no contexto da Universidade de Brasília?

\subsection{Objetivo Geral}

Descrever como são estabelecidas as transferências internas de alunos entre as mudanças de curso de graduação na Universidade de Brasília.

\subsection{Objetivos Específicos}

O objetivo geral desse estudo encontra-se desmembrado entre os seguintes objetivos específicos:

1. Identificar as propriedades da rede de transferência interna e como são estabelecidas as mudanças de curso e seus reflexos no fluxo entre os turnos e entre os campi da UnB. 
2. Verificar como ocorrem as transferências internas de alunos entre os cursos conforme as áreas de conhecimento e a (des)necessidade de mecanismos de bonificação.

3. Investigar o efeito trampolim nos fluxos de transferência interna de alunos entre os cursos de graduação.

\subsection{Justificativa}

Embora a literatura relacionada à evasão no ensino superior possa ser robusta, os estudos tendem a abordá-la sem adentrar pontos específicos, a exemplo da mudança de curso. Entre aqueles que o fazem, tende-se a ressaltar a necessidade de políticas de flexibilização de realocação de estudantes entre cursos de graduação (SAMPAIO et al., 2011), com a finalidade de aumentar o quantitativo de alunos diplomados (ORTIZ; DEHON, 2013).

É sabido que a mudança de curso é influenciada por diversos fatores e pode ocorrer, basicamente, via novo exame externo de seleção, a exemplo do vestibular, ou via seleção interna, a exemplo da transferência interna. Quanto a essa última, ela pode ser analisada sob duas óticas: em relação ao curso de origem e em relação ao curso de destino.

Sob o ponto de vista do curso que recepciona alunos transferidos, a mudança de curso pode ser compreendida como uma alternativa ao preenchimento de vagas ociosas, o que contribui para amenizar a evasão no ensino superior (DIAS SOBRINHO, 1999; RISTOFF, 1999; VELLOSO; CARDOSO, 2008). Ao mesmo tempo, sob a ótica do curso que registra a saída de estudantes, a mudança de curso pode ser considerada evasão e, dessa forma, uma maneira de desperdício de recursos públicos (SILVA FILHO et al., 2007).

Sob essa perspectiva, cada matrícula realizada sem a futura contrapartida diplomação gera desperdício de ordem social, acadêmica e econômica (HOTZA; LUCCHIARI, 1998; DIAS; THEÓPHILO; LOPES, 2010), além de que até a reputação da instituição de ensino superior passa a ser questionável (ROVIRA, 
2001), tendo em vista que a evasão "prefigura na lista dos indicadores de baixa eficiência do sistema de educação superior" (BRITO, 2013, p. 118).

A abordagem das transferências internas pode contribuir à melhor gestão universitária, assim como para a melhor gestão econômica das finanças públicas. A compreensão dos fatores relacionados às mudanças de cursos pode contribuir também à formulação de políticas e normas que estimulem pontos positivos e minimizem ou eliminem pontos negativos presentes no processo. No presente estudo, optou-se pela análise social de redes, a qual pode ser utilizada para se mapear a posição assumida por cada ator em dado grupo e se entender como são estabelecidas as vinculações dentro dele (LIMA; MEIRINHOS, 2010).

Justifica-se a escolha da Universidade de Brasília considerando-se que 0 fenômeno da evasão não é recente na UnB, conforme resultados dos estudos de Kipnis e Bareicha (1998) e Cunha, Tunes e Silva (2001). 


\section{REFERENCIAL TEÓRICO}

O referencial teórico encontra-se estruturado em três blocos. O primeiro é destinado à abordagem das Redes Sociais, assim como as suas principais propriedades elencadas pela literatura e aplicáveis ao presente estudo. O segundo bloco é orientado à discussão acerca da evasão de mudança de curso, bem como as principais influências sobre esse fenômeno. O terceiro aborda as regras de transferências internas adotadas pela Universidade de Brasília e por outras universidades públicas brasileiras.

\subsection{As redes sociais}

A análise de redes pode ser considerada uma abordagem plural aplicável a diversos contextos e questões de variados campos (MARTELETO, 2001), a exemplo da Ciência da Computação, Física, Biologia, Sociologia, tendo como origem a teoria dos grafos na Matemática (METZ et al., 2007). Os exemplos de aplicação encontrados na literatura corroboram essa diversidade.

Neste interim, podem ser citadas: as abordagens de conexão entre indivíduos, redes organizacionais, redes neurais, redes metabólicas, cadeia alimentar, interações entre citações em artigos científicos, entre páginas da Web, a transferência de informação, os fluxos migratórios entre regiões e entre países (FAWCETT, 1989; MARTELETO, 2001; NEWMAN, 2003; METZ et al., 2007; FIGUEIREDO, 2011), entre outros.

No campo das Ciências Sociais, é significativa a evolução da análise de redes devido, sobremaneira, à capacidade dela de congregar técnicas quantitativas e qualitativas, contribuindo para a consolidação da teoria social geral (FAZITO, 2002). O início dos estudos nessa área remota à década de 1930, quando sociólogos começaram a abordar o comportamento da sociedade e os relacionamentos dos indivíduos por meio de redes (METZ et al., 2007). 
Uma rede é um grafo abstrato constituído de pontos (vértices, nós ou atores) relacionados que possuem conexões ou não entre si (relações, laços ou arestas) simbolizando as relações entre entidades, entre objetos de qualquer natureza e até mesmo entre pessoas (NEWMAN, 2003; FAZITO, 2002). Normalmente, essas relações envolvem trocas, podendo ser tangíveis - a exemplo de bens e materiais, ou intangíveis - como ideias e valores (FERREIRA; VITORINO FILHO, 2010).

Em geral, denomina-se rede social o estudo de grafo envolvendo conectividade entre pessoas. Destarte, uma rede social é uma configuração de relacionamentos entre pessoas ou grupos de pessoas que contém determinado padrão de contatos ou interações dentro de um determinado sistema (FAZITO, 2002; NEWMAN, 2003). A depender do tipo de relacionamento analisado, um mesmo conjunto de pessoas pode apresentar diferenciadas configurações de rede (FIGUEIREDO, 2011).

Segundo Fazito (2002), a análise de redes sociais lida com dados relacionais dos atores em detrimento dos atributos deles, diferenciando-se, por conseguinte, a análise de rede social da estatística tradicional. Significa dizer que a estrutura social da rede é percebida em função das interações entre os indivíduos e não pelo conjunto de características individuais deles, tais como classe, sexo, idade e gênero (MARTELETO, 2001). À vista disso, os relacionamentos entre os atores podem ser descritos a partir das posições e papéis desempenhados por eles na estrutura de uma rede social (FAZITO, 2002), sendo que "essa estrutura gera influência sobre as escolhas, as orientações, os comportamentos e as opiniões dos indivíduos" (MARTELETO, 2001, p. 72).

A estrutura de uma rede é dada em função do relacionamento entre seus elementos e pode fornecer importantes indícios acerca dos fenômenos que ocorrem nela, assim como os principais atores e as vantagens ou desvantagens dadas a eles por ocuparem determinada posição na estrutura dela (MARTELETO, 2001; HANNEMAN; RIDDLE, 2005; FIGUEIREDO, 2011). Neste interim, a posição assumida por determinado ator em dada rede pode, por exemplo, sugerir importantes indícios acerca das restrições enfrentadas por ele ou das oportunidades usufruídas por ele (HANNEMAN; RIDDLE, 2005).

Como exemplo, uma posição favorável em dada rede pode proporcionar poder a um ator, traduzido em termos de melhores barganhas e influências sob os 
demais atores da rede (HANNEMAN; RIDDLE, 2005). Em geral, uma posição favorecida está atrelada à quantidade de ligações que um ator possui (degree), à maior proximidade e, consequente, acessibilidade em relação aos demais atores da rede (closeness) e a localização em posição intermediária entre um par de atores (betweenness).

A direção das interações entre os atores também revelam muitas características de uma rede como um todo (METZ et al., 2007). A interação entre dois atores pode ser classificada de duas maneiras a depender da quantidade de direções que ela representa. Quando sinalizando apenas uma direção, isto é, saindo de um vértice e apontando para outro, diz-se que a interação é direcionada ou assimétrica (METZ et al., 2007; FIGUEIREDO, 2011). Quando une dois vértices e, ao passo que sai de um ela aponta para outro vértice e vice-versa, a interação é denominada de não-direcionada, bidirecional ou simétrica (MARTELETO, 2001; NEWMAN, 2003; METZ et al., 2007; FIGUEIREDO, 2011).

Em outras palavras, uma interação direcionada é aquela em que $A \rightarrow B$ não implica, necessariamente, na interação recíproca $B \rightarrow A$. Diferentemente, quando não direcionada, configura-se na relação recíproca de $B \rightarrow C$ como $C \rightarrow B$, isto é, $B \leftrightarrow C$. $A$ figura 1 ilustra uma interação direcionada entre os vértices $A$ e $B$ e uma não direcionada entre os vértices $\mathrm{B}$ e $\mathrm{C}$.

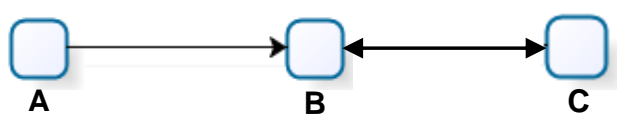

Figura 1 Relação direcionada e não-direcionada entre vértices de uma rede

De acordo com Hanneman e Riddle (2005), em redes não direcionadas, a distinção entre os vértices faz-se por meio da quantidade de interações que eles possuem entre si. Nas redes direcionadas, por sua vez, há diferenciação entre os vértices a depender da direção das interações entre eles: os vértices que recebem muitas interações são denominados de proeminentes, ao passo que aqueles que emitem interações são chamados de influentes (HANNEMAN E RIDDLE, 2005). 
De acordo com Fazito (2002), a análise de redes sociais pode ser realizada sob dois níveis de análise complementares, a depender do problema empírico: redes egocentradas (egocentric networks), organizadas em torno de apenas um ator, e redes totais (full networks), configuradas por diversos atores interligados. Considerando que o foco da análise de redes sociais reside em interações coletivas, a perspectiva das redes totais é apontada por Fazito (2002) como a mais adequada para "explicar a ocorrência de diferentes estruturas e como elas interferem ou não nos comportamentos dos atores" (FAZITO, 2002, p. 18).

\subsection{Propriedades das redes sociais}

O conhecimento das propriedades estruturais de uma rede possibilita inferências e generalizações por meio de observações dela (FIGUEIREDO, 2011). Segundo esse autor, "basta que a rede possua tal propriedade para que tal fenômeno se comporte de tal maneira, sem que seja necessário conhecer maiores detalhes da estrutura da rede" (FIGUEIREDO, 2011, p. 308). Em outras palavras, a presença de determinada propriedade estrutural em determinada rede induz a presença de um determinado comportamento funcional (FIGUEIREDO, 2011). Nos tópicos abaixo são abordadas algumas das propriedades das redes sociais, tais como densidade, grau, centralidade e intermediação, sendo que essas estão entre as principais medidas propriedades presentes em redes, segundo Fazito (2002).

\subsubsection{Densidade}

A densidade de uma rede é, de modo geral, uma propriedade dada pela fração de relacionamentos que existem nela (FIGUEIREDO, 2011), revelando a coesão existente entre os vértices pertencentes à rede (BARBASTEFANO et al., 2013). A densidade pode ser expressa em medidas descritivas ou estruturais (FAZITO, 2002). Como métrica descritiva, a densidade é o resultado da divisão do quantitativo de conexões existentes entre os nós de uma rede pela quantidade de conexões possíveis de serem formadas nela, isto é, a quantidade de laços efetivos 
perante aqueles que são possíveis (FAZITO, 2002; GUIMARÃES; MELO, 2005). Segundo Everton (2012), a densidade para redes não-direcionadas pode ser encontrada da seguinte forma:

$$
\text { Densidade }=\frac{\mathrm{L}}{\frac{\mathrm{n}(\mathrm{n}-1)}{2}}
$$

em que $L$ é a quantidade de arestas da rede, $n$ é a quantidade de vértices da rede, (n-1) a quantidade máxima de arestas possíveis que incidem em um vértice. No que concerne a redes direcionadas, a fórmula sofre uma pequena adaptação, pois não se divide o denominador por 2 , já que cada aresta no numerador não mais está sendo contada em duplicidade (PRELL, 2012). Assim:

$$
\text { Densidade }=\frac{L}{n(n-1)}
$$

em que as demais variáveis representam os mesmos elementos da fórmula para redes não-direcionadas, acima descrita.

A densidade como grandeza descritiva representa uma "medida do grau de inserção dos atores na rede", ao passo que em sentido de grandeza estrutural, ela "mede o grau de coesão e homogeneidade" (FAZITO, 2002, p. 22). Tanto a densidade descritiva quanto a estrutural de uma rede é dada em função, sobremaneira, das ligações ou contatos existentes entre os nós.

Segundo Everton (2012), os valores possíveis para a densidade descritiva situam-se entre 0 (ausência de interações entre os vértices da rede) e 1 (todas as possíveis interações entre os vértices estão presentes na rede). Em relação à rede como um todo, valores expressivos de densidade sugerem a existência de ligações fortes entre os componentes da rede, ao passo que valores inexpressivos sinalizam para a ocorrência de ligações fracas (NEWMAN, 2003). A expressividade da densidade pode fornecer indícios acerca da presença ou não de poder em determinada rede (HANNEMAN; RIDDLE, 2005).

Ademais, quanto maior o tamanho de uma rede, menor tende a ser a densidade dela (PRELL, 2012). Esse relação inversa é atribuída ao fato de que "o número de linhas potenciais aumenta exponencialmente quando vértices são inseridos na rede, todavia o número de interações de cada vértice tende a continuar 
limitado" (EVERTON, 2012, p. 33). Dessa forma, muitos pesquisadores preferem adotar a apuração do grau médio da rede para mensurar densidade (EVERTON, 2012).

\subsubsection{Grau}

O grau corresponde a quantidade de arestas que incidem sobre um dado vértice, simbolizando as interações dele com os demais da rede (FIGUEIREDO, 2011). Dessa maneira, o grau assume algum valor entre 0 (quando determinado vértice não se encontra relacionado a nenhum outro vértice) ou n-1 (quando o vértice está conectado a todos os demais da rede), sendo $n$ a quantidade de vértices da rede. Considerando que uma aresta conecta dois vértices, então isso implica que a soma de todas as arestas de uma rede equivale à metade da quantidade de vértices pertencentes a ela (FIGUEIREDO, 2011).

A partir do valor de grau encontrado, pode-se encontrar o grau médio realizando-se, para tanto, uma média aritmética. Outro conceito relevante é a distribuição do grau. Trata-se, basicamente, da distribuição de frequência dos vértices de uma rede que possuem o mesmo grau. Em outras palavras, "é a fração de vértices da rede que possui grau igual" (FIGUEIREDO, 2011, p. 311).

\subsubsection{Centralidade}

A centralidade é considerada de maneira unânime uma medida estatística de destaque entre as análises de redes sociais (HANNEMAN; RIDDLE, 2005), embora a definição do que seja centralidade, assim como a maneira de calculá-la careçam de consentimento na literatura (HANNEMAN; RIDDLE, 2005). Comumente, ela é calculada com base na quantidade de interações existentes entre os vértices de uma rede, sendo que quanto maior a quantidade de interações, mais central é o ator (MARTELETO, 2001; FAZITO, 2002; NEWMAN, 2003).

Ademais, a posição central de uma rede geralmente sugere poder ao ator que a ocupa e um olhar para a rede como um todo pode sugerir quão centralizado o 
grafo é ou quão desigual é a distribuição de centralidade nele (HANNEMAN; RIDDLE, 2005). Há diferentes maneiras de se identificar a centralidade de uma rede. Entre as principais, Hanneman e Riddle (2005) destacam a abordagem de Freeman e de Bonacich.

Para Linton Freeman, uma rede estrelar (star network) representaria a disposição de rede de modo mais centralizado e, consequentemente, mais desigual possível, independentemente da quantidade de vértices (HANNEMAN; RIDDLE, 2005). Conforme ensinam esses autores e ilustrado na figura 2, numa rede em disposição de estrela todos os vértices periféricos possuem grau de interação igual a 1 , com exceção do vértice central que possui quantidade de interações igual ao número de vértices da rede menos 1.

Tomando essa configuração de rede como parâmetro, o método de Linton Freeman compara, em termos percentuais, o grau de desigualdade ou variância de uma dada rede com os valores de uma rede estrelar perfeita de mesmo porte (HANNEMAN; RIDDLE, 2005).

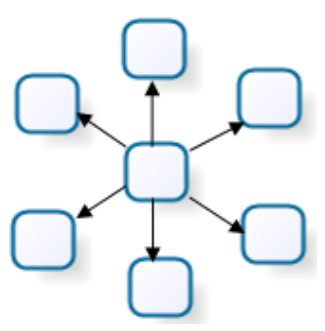

Figura 2 Star network (rede estrelar)

Por sua vez, a abordagem de centralidade proposta por Bonacich é mais amplamente aceita do que a tradicional, a qual atribui maior centralidade à medida que o vértice possui maior quantidade de interações. A centralidade de Bonacich considera não apenas as interações diretamente estabelecidas por um dado vértice, mas também as conexões estabelecidas pelos vértices adjacentes a ele com os demais da rede (HANNEMAN; RIDDLE, 2005).

Não obstante, Bonacich questiona também a associação tradicional feita entre centralidade e poder. Para ele, a presença de conexões de um vértice com seus adjacentes o torna central, porém não 0 atribui poder. Ou seja, centralidade não significa, necessariamente, poder (HANNEMAN; RIDDLE, 2005). O conceito de centralidade baseado no grau de interações dos vértices com os demais de uma 
rede pode ser abrandado pela presença de aberturas estruturais entre eles, conforme salientado por Marteleto (2001).

Segundo essa autora, a concepção de abertura estrutural está atrelada à otimização e à maximização das interações de um ator com os demais, o que pode impactar na centralidade dele na rede. Dessa forma, "um indivíduo com poucas relações diretas pode estar muito bem posicionado em uma rede por meio da utilização estratégica de suas aberturas estruturais" (MARTELETO, 2001, p. 76).

Conforme introduzido anteriormente na sessão sobre redes sociais, as interações em redes direcionadas podem ser expressas em relação à quantidade de setas que apontam para determinado ator, denominadas como in-degree centrality e a quantidade delas que saem desse ator e apontam para algum outro, conhecidas como out-degree centrality. Se um ator recebe várias setas, eles são denominados de proeminentes e possuem alto prestígio na rede ou pode ser um indício de gargalo, ao passo que se ele emite setas, diz-se se tratar de um ator influente (GUIMARÃES; MELO, 2005; HANNEMAN; RIDDLE, 2005).

Conforme Guimarães e Melo (2005), a articulação de um ator numa rede pode ser mensurada por meio do somatório do quantitativo de setas que apontam para ele (in-degree) com o quantitativo de setas que saem dele (out-degree). Por outro lado, conforme Hanneman e Riddle (2005), a centralidade pode ser mensurada desprezando-se a direção das interações sendo que, nesse caso, uma interação bidirecional é computada como apenas uma.

Conforme ressaltado por Hanneman e Riddle (2005), as interações dos vértices para com a rede como um todo não são levadas em consideração nas abordagens de Freeman e de Bonacich, as quais consideram, respectivamente, a quantidade de interação dos vértices entre si e a quantidade de interação dos vértices adjacentes. Dessa forma, apesar de um vértice e os adjacentes a ele estarem interagindo com vários outros nas redondezas, mesmo assim ainda podem estar desconectados da rede como um todo (HANNEMAN; RIDDLE, 2005).

\subsubsection{Grau de intermediação}

A centralidade de intermediação, conforme sugerido pelo termo, é uma métrica voltada à apuração do papel desempenhado por determinado ator como 
intermediário entre a ligação de outros atores. Na definição de Marteleto (2001), é o cálculo para se demonstrar o papel desempenhado por determinados vértices como intermediários ou pontes entre os demais. É usado, também, para se evidenciar a influência de intervenção que dado vértice pode exercer sobre os demais na rede (FAZITO, 2002; NEWMAN, 2004), o que pode ser de suma relevância em estudos envolvendo, sobremodo, redes de comunicação e poder (PRELL, 2012).

Trata-se de uma métrica mais intuitiva sobre a estrutura de uma rede quando comparada aos graus de centralidade de entrada e de saída, pois refere-se à posição de um ator para com a rede inteira e não apenas as interações que são estabelecidas aos arredores dos atores (PRELL, 2012). Ao passo que os graus de centralidade fornecem informações quantitativas acerca das interações estabelecidas, o grau de intermediação informa a relevância da posição do ator na rede (PRELL, 2012). A centralidade de intermediação de um ator $k$ pode ser encontrada por:

$$
C_{\text {intermediaçẫo }}(k)=\frac{\sum \partial i k j}{\sum \partial i j}
$$

em que $\partial i k j$ representa o número de ligações geodésicas entre os vértices i e j que passam pelo vértice $k$, ao passo que $\partial$ ij corresponde ao número de ligações geodésicas entre os vértices i e j (PRELL, 2012).

\subsection{As aglomerações de uma rede}

Uma rede de relacionamentos sociais pode ser estruturada por redes secundárias, também denominadas como subgrupos, cliques ou n-cliques (KADUSHIN, 2012; PRELL, 2012). Essas estruturas menores podem fornecer indícios que auxiliam a entender os papéis exercidos por cada componente da rede e, por conseguinte, na compreensão da rede como um todo (MARTELETO, 2001; PASCOTTO et al., 2013).

Um subgrupo refere-se a uma área de uma rede composta por interações entre atores, sendo que a menor dimensão é uma díade, isto é, conexão entre dois atores, e a maior dimensão é, logicamente, menor do que a rede como um todo (PRELL, 2012). A interação dentro de um subgrupo ocorre de maneira mais intensa 
quando comparada à interação com atores externos a ele (PASCOTTO et al., 2013). Não obstante, a abordagem de subgrupos envolve a investigação de coesão entre eles.

Segundo Prell (2012), a definição de coesão de um subgrupo é multifacetada e tem sido estudada por sociólogos, cientistas políticos e psicólogos. É recorrente o uso da definição genérica dada por Kurt Lewin, o qual considera coesão em dado subgrupo como um campo de forças que mantém pessoas unidas em dado grupo ou rede (PRELL, 2012). Entre as principais formas de mensurar e analisar a coesão de subgrupos estão as abordagens de cliques, n-cliques, k-cores, Newman-Girvan e análise de facções (HANNEMAN; RIDDLE, 2005; PRELL, 2012).

A concentração e a formação de subgrupos numa determinada rede pode ser analisada pela métrica dos cliques (FAZITO, 2002). A principal diferença de um clique para o restante da rede é a presença de forte senso de coesão entre seus membros, os quais se relacionam por meio de interações recíprocas (PRELL, 2012). A presença de atores concomitantemente em mais de um clique pode dificultar as análises, o que é denominado pela literatura como overlap. Para contornar esse empecilho, pesquisadores desenvolveram o método do $\mathrm{n}$-clique. Um subgrupo segundo a análise de n-clique é aquele em que um par de atores está conectado a outros atores segundo uma quantidade $n$ de interações (PRELL, 2012).

Outro método de abordagem da coesão entre subgrupos é o k-cores, o qual não investiga a existência de coesão em si, mas sim da identificação de grupos coesos (PRELL, 2012). A depender do valor de $k$ obtido por um ator, ele será parte ou não de um subgrupo. O valor $k$ depende do grau de centralidade do ator na rede. Dessa forma, quanto menor o valor $k$ considerado, mais leniente se é para a entrada de novos membros no subgrupo, tornando-o robusto. Contrariamente, quanto maior o valor de $k$, maior a rigidez de ingresso no subgrupo e menor a sua extensão (PRELL, 2012).

O algoritmo de Newman-Girvan decompõe uma rede extensa em aglomerações menores (PRELL, 2012). Essa decomposição considera os atores mais estreitamente conectados entre si, em detrimento daqueles mais afastados (HANNEMAN; RIDDLE, 2005). Para tanto, o algoritmo identifica quais são os atores que se localizam como intermediários de subgrupos coesos e, a partir disso, procede à remoção deles. Esse processo de fragmentação prossegue até a obtenção de subgrupos isolados. 
Por fim, o método de análise de facções compara o modelo de uma rede efetiva com 0 modelo de uma idealizada de mesmo porte indicando, por conseguinte, o quanto aquela se ajusta nessa (EVERTON; 2012). Essa análise é expressa em termos de badness of fit, isto é, um indicador de erro para o mau ajuste entre os modelos, sendo que quanto menor o valor, maior é a precisão.

Em outras palavras, o badness of fit é uma medida da quantidade de vezes em que uma aresta está presente ou ausente, quando em verdade deveria estar, respectivamente, ausente ou presente (EVERTON, 2012). Sendo assim, o valor zero indica um tipo de ajuste perfeito. Outra maneira de se representar o descompasso de ajuste entre o modelo de uma rede efetiva e o modelo idealizado dela é por meio do indicador final proportion correct. Esse indicador possui a mesma finalidade do anterior, que é apurar o grau de ajuste. Entretanto, não se baseia na quantidade de erros do ajuste, mas sim acertos. Destarte, quanto maior o valor encontrado, melhor.

\subsubsection{A análise de aglomerações}

A análise de aglomeração é aplicada em estudos das mais diversas áreas, como psicologia, biologia, sociologia, economia, engenharia e administração (HAIR, 2005). Segundo Borgatti, Everett e Johnson (2013), há uma variedade de técnicas que permitem identificar áreas dentro de uma rede que estão estritamente ligadas, formando-se, dessa forma, agrupamentos.

A técnica de análise de agrupamentos ou análise de cluster consiste em, basicamente, agrupar dados que são similares entre si criando, assim, grupos homogêneos. Como consequência, esses grupos homogêneos se diferem em relação aos demais ocasionado, por conseguinte, dissimilaridades entre eles. Em outras palavras, essa técnica "maximiza a homogeneidade de objetos dentro de grupos, ao mesmo tempo em que maximiza a heterogeneidade entre os grupos" (HAIR, 2005, p. 191).

Para se realizar esse agrupamento de dados similares, faz-se necessária a adoção de algum algoritmo, isto é, "um conjunto de regras ou procedimentos" (HAIR, 2005 , p. 382). Por sua vez, os algoritmos são subdivididos em não-hierárquicos e hierárquicos. Basicamente, a diferença entre eles consiste em se permitir ou não, respectivamente, a reclassificação das observações ou dos grupos de observações. 
Em outras palavras, ao passo em que nos algoritmos não hierárquicos os elementos podem ser deslocados de um grupo para outro, nos hierárquicos, uma vez combinados os elementos não mais se separam (MATOS, 2007).

No que concerne aos algoritmos hierárquicos, o grau de similaridade entre os casos pode ser visualizado por meio de gráficos de árvore e dendogramas (HANNEMAN; RIDDLE, 2005; MALHOTRA, 2008). Há duas modalidades de análise: os aglomerativos e os divisivos. Nos algoritmos aglomerativos, o cluster inicia-se com cada objeto em clusters separados, os quais vão aumentando à medida que novos objetos são adicionados, continuando o processo até que todos objetos integrem um único cluster (MALHOTRA, 2008).

De modo oposto, os objetos ficam dispostos num único cluster nos algoritmos divisivos, sendo que são paulatinamente partidos até que cada objeto esteja num cluster separado (MALHOTRA, 2008). Segundo Matos (2007), os algoritmos aglomerativos são os mais empregados na literatura, ao passo que o custo operacional dos algoritmos divisivos é elevado. A figura 3 ilustra as duas modalidades, sendo representado em 3(a) os procedimentos de análise dos algoritmos aglomerativos e em $3(b)$ dos algoritmos divisivos.

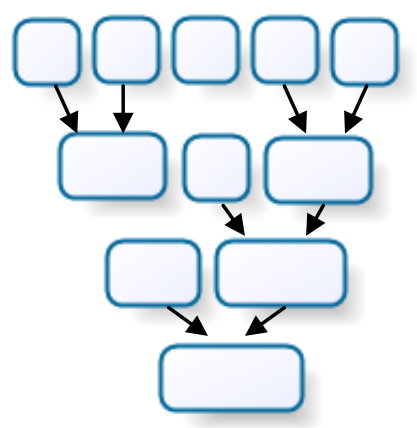

3(a)

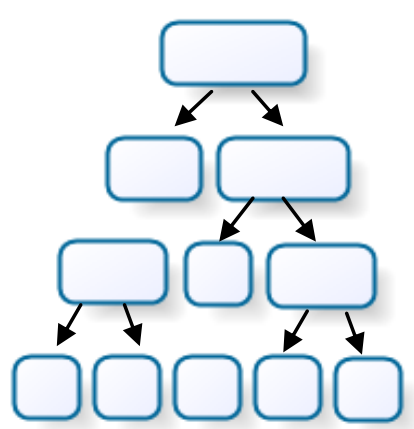

$3(b)$

Figura 3 llustração de algoritmos aglomerativos (a) e divisivos (b)

O mecanismo de análise dos algoritmos hierárquicos aglomerativos fundamenta-se, em suma, na identificação de elementos similares, agrupamento deles entre si e posterior busca por novas similaridades entre os demais elementos 
(HAIR, 2005). As quatro etapas são pormenorizadas a seguir (HAIR, 2005; HANNEMAN; RIDDLE, 2005; BORGATTI; EVERETT; JOHNSON, 2013):

1. Na primeira rodada o par ou conjunto de elementos mais similares ou mais próximos é detectado;

2. Esse par ou conjunto de elementos é agregado num único grupo sob algum método e, uma vez que um elemento é reunido em determinado grupo, nele permanecerá;

3. Sob algum critério, novas medidas de similaridade ou proximidade são detectadas;

4. Seguem-se sucessivamente novos agrupamentos e a averiguação de similaridade ou proximidade até que todos os elementos sejam alocados num único conglomerado.

Como ressaltado na etapa 2, o agrupamento é realizado em conformidade com alguns métodos, dentre os quais Malhotra (2008) destaca: os métodos de ligação ou encadeamento (linkage methods), os métodos de variância - que engloba o método Ward, e os métodos de centróide.

Entre os métodos de ligação ou encadeamento (linkage methods) estão: ligação simples ou encandeamento único (single linkage); ligação ou encadeamento completo (complete linkage); ligação ou encadeamento médio (average linkage). Respectivamente, esses métodos levam em consideração o vizinho mais próximo, o vizinho mais distante e a média da distância entre todos os pares quando do cálculo e recálculo da matriz contendo as similaridades ou proximidades (MATOS, 2007).

Segundo Hanneman e Riddle (2005), o método da ligação simples calcula as semelhanças com base nas distâncias mínimas entre os elementos ou grupos. Por seu turno, o método da ligação completa apura semelhanças considerando as distâncias máximas entre os elementos ou grupos. Por fim, o método da média calcula a semelhança das pontuações médias no cluster recém-formado a todos os outros grupos. 


\subsection{As transferências internas de alunos: evasão?}

Em consonância com a tipologia definida pela Comissão Especial de Estudos Sobre Evasão nas Instituições Públicas de Ensino Superior do Ministério da Educação - MEC (BRASIL, 1997), Lobo (2012) ressalta três tipos não excludentes de evasão: i) a evasão do curso - quando o aluno muda de curso permanecendo na IES ou migrando para outra; ii) evasão da instituição de ensino - quando o aluno muda de instituição; e iii) evasão do sistema - quando o aluno abandona o ensino superior como um todo.

Quanto à evasão do curso, a literatura emprega diversos termos para se referir à saída do aluno de um curso para outro, não distinguindo, a exemplo de Dias, Theóphilo e Lopes (2010), se a mudança ocorre via aprovação em novo vestibular ou via transferência interna. Entre os termos empregados, citam-se: mudança de curso, transferência interma, reopção de curso, re-escolha profissional; troca de curso, evasão de curso, mobilidade acadêmica, course changes, entre outros (HOTZA; LUCCHIARI,1998; DIAS SOBRINHO, 1999; MCMILLAN, 2005; VELLOSO; CARDOSO, 2008; BRITO, 2013). No presente estudo, adota-se o termo transferência interna como sinônimo para mudança de curso.

As evidências da literatura apontam que parcela do que se computa como evasão é, em verdade, mudança de curso dentro de uma mesma Instituição de Ensino Superior - IES ou transferências para outras, conforme constatado por Dias, Theóphilo, Lopes (2010) e Vries et al. (2011). Esses movimentos entre cursos e/ou entre instituições é denominado por Dias Sobrinho (1999) e Ristoff (1999) como mobilidade acadêmica. Segundo Ristoff (1999), parte do que é considerado evasão e desperdício é, de fato, mobilidade e investimento, os quais ao possibilitar a mudança de curso proporcionam crescimento ao indivíduo canalizando-o a suas reais potencialidades.

Compartilhando da posição de Dias Sobrinho (1999), Velloso e Cardoso (2008) não consideram a mudança de curso como evasão propriamente dita. Neste ínterim, a falta de consenso na literatura sobre o conceito de evasão pode ser empecilho às análises comparativas entre estudos que abordam essa temática, podendo levar a interpretações enganosas (VELLOSO; CARDOSO, 2008). Como reflexo acerca da ausência de consenso conceitual, a evasão pode ser calculada de variadas 
maneiras, sob diferentes critérios. Para contornar isso, recomenda-se a busca pela constância quanto à metodologia adotada no intuito de viabilizar melhores análises e comparações longitudinais (LOBO, 2012). Idealmente, a melhor maneira para se medir a evasão é acompanhar cada estudante ao longo da jornada acadêmica, todavia, dada a inviabilidade disso, recorre-se aos dados agregados (LOBO, 2012).

Em se tratando de dados agregados, Velloso e Cardoso (2008) criticam a metodologia de cálculo da evasão a qual se pauta nas diferenças dos quantitativos de matrículas entre um ano e outro, subtraindo-se do ano inicial os concluintes e, do ano seguinte, os ingressantes. Segundo esses autores, os resultados, sob essa ótica, tendem a subestimar o real valor, tendo em vista que dados relativos a mudança de curso e/ou transferência entre IES não são considerados (VELLOSO; CARDOSO, 2008).

De maneira geral, "os dados habitualmente disponíveis na educação superior geralmente não distinguem entre mobilidade e evasão real" (VELLOSO; CARDOSO, 2008, p. 2). E mesmo quando há distinção, enfrenta-se ainda o dilema entre incluir ou não os dados relativos à mobilidade entre cursos entre os alunos ingressantes ou entre aqueles evadidos ou, ainda, em ambos. Em estudo empírico, Vries et al. (2011) averiguaram que entre os alunos considerados evadidos, 31,9\% deles estavam, na verdade, matriculados em outros cursos na mesma IES. Em conformidade a isso, um aluno que muda de curso dentro da mesma IES pode ser considerado evadido para o curso, mas não o é para a instituição (DIAS SOBRINHO, 1999; LOBO, 2012; BRITO, 2013; VELLOSO; CARDOSO, 2008).

A mudança de curso é um modo de o estudante se adaptar ao sistema acadêmico (MAGALHÃES; REDIVO, 1998; SBARDELINI, 2001). É, também, uma alternativa que pode atenuar os índices de abandono do ensino superior (SBARDELINI, 2001). Dessa forma, é relevante evidenciar que, conforme sublinhado por Barefoot (2004), abandonar um curso não corresponde, necessariamente, ao abandono da instituição ou a saída permanente do ensino superior. Ademais, impende salientar que são distintos os motivos que levam o estudante a migrar de curso ou IES e aqueles que o levam a abandonar permanentemente o ensino superior (STRATTON; O'TOOLE; WETZEL, 2008; HOVDHAUGEN, 2011).

Quanto ao ingresso, segundo Lobo (2012), a partir do ano de 2009 o Instituto Nacional de Estudos e Pesquisas - INEP passou a não considerar como novos 
ingressantes os dados relativos às transferências internas entre cursos dentro de uma mesma Instituição de Ensino Superior. Consequentemente, esse procedimento implicou em virtual redução da taxa de evasão (LOBO, 2012).

Buscando alinhar as metodologias voltadas ao cômputo dos níveis de evasão nas IES, o Tribunal de Contas da União - TCU estabeleceu, por meio Decisão Plénário TCU no 408/2002, indicadores que auxiliam no processo de acompanhamento do desempenho delas em relação a esse assunto. Entre esses indicadores, sublinha-se a Taxa de Sucesso calculada como a razão entre o número total de diplomados e o número total de ingressantes, ajustados segundo o ano de ingresso discente na universidade e a duração padrão do curso, conforme entendimento da Secretaria de Educação Superior do Ministério da Educação - MEC para cada curso (GOMÉZ; TORRES, 2015).

Vale salientar que como ingressantes não são computados os estudantes que mudam de curso dentro de uma mesma IES. Ademais, o indicador de Taxa de Sucesso ao considerar um período de tempo previamente fixado, deixa de considerar alunos que se graduam fora desse prazo (BRASIL, 2015).

\subsection{Motivos que influenciam a Mudança de Curso}

A mudança de curso de graduação, segundo a literatura, pode ser influenciada por motivos variados, sejam eles de ordem pessoal ou institucional, sendo pouco provável que um único fator possa ser responsabilizado (MCMILLAN, 2005; ANDRIOLA; ANDRIOLA; MOURA, 2006). Quando da publicação do estudo de McMillan (2005), a mudança de curso era, segundo esse autor, um assunto analisado secundariamente entre os estudos acerca da evasão no ensino superior. Entre a literatura mais recente, ainda é possível se perceber a pontualidade na abordagem desse tema, embora com maior quantidade de indícios.

A manifestação de interesse por outra graduação é justificável quando levado em consideração que a escolha do curso superior pelo aluno geralmente ocorre em idade ainda precoce (BRASIL, 1996; BARDAGI, HUTZ, 2009; REIS; CUNHA; SPRITZER, 2012). Até o momento de escolha do curso, é possível se destacar dois 
principais grupos: um de estudantes que de antemão estão decididos sobre a carreira profissional já durante o ensino médio e outro de estudantes que por muito tempo permanecem indecisos (OQUENDO, 2008).

É esperado que o estudante ingresse no ensino superior tão logo conclua o ensino médio. Todavia, as chances de mudança de curso entre estudantes que o fazem são maiores do que àquelas entre estudantes que adiam o ingresso na universidade (McMILLAN, 2005). Infere-se, assim, que o transpassar do tempo colabora para uma espécie de maturidade vocacional do estudante, conforme sugere o estudo de Magalhães e Redivo (1998), diminuindo as possibilidades de escolha equivocada de curso (OQUENDO, 2008).

A indecisão quanto à formação superior pode ser motivada, entre outros fatores, pela insegurança do estudante em eleger uma carreira, sobremaneira quando ele possui diversas informações que o levam ao interesse por mais de uma área (DIAS; THEÓPHILO; LOPES, 2010). De modo oposto, Hotza e Lucchiari (1998) salientam que a indecisão pode ser ocasionado também pelo desconhecimento dos cursos e carreiras profissionais pelo estudante, ou seja, pela falta de informações. Nesse sentido, o desconhecimento sobre determinado curso e carreira pode impelir à evasão, conforme evidências dos estudos de Bardagi e Hutz (2009) e Gomes et al. (2010).

É sabido que o aluno está vulnerável à frustração com o curso superior, seja pela influência de fatores de ordem pessoal, como a escolha equivocada do curso, seja por fatores externos, tais como relacionados à instituição, por exemplo. A frustração com a Instituição pode começar já no primeiro semestre de estudos, sendo que há registros de quantidade expressiva de trancamentos de matrícula antes mesmo da conclusão da carga-horária inicial do curso (DULLIIUS; CYRNE, 2010), o que é qualificada por Oquendo (2008) como evasão prematura. Vale salientar que "fatores de ordem institucional podem concorrer para o desinteresse e até o desencanto dos estudantes em relação ao próprio curso escolhido" (BRASIL, 1997, p. 121).

No que concerne às escolhas equivocadas de curso superior, entre as estratégias para amenizá-las, destacam-se o suporte vocacional ou a orientação profissional como importantes nesse processo de escolha (HOTZA; LUCCHIARI, 1998; ANDRIOLA; ANDRIOLA; MOURA, 2006). O momento de decidir o curso 
superior ganha mais relevância ao se notar, conforme Dias, Theóphilo e Lopes (2010), falhas nessa etapa frequentemente são associadas às evasões.

Entre as alternativas para amenizar as evasões de curso, McMillan (2005) sugere a implementação de cursos generalistas no primeiro ano de graduação. Por cursos generalistas, entende-se a oferta de disciplinas de formação comum a várias carreiras. Após cursadas essas disciplinas, estaria o estudante mais habilitado a decidir sobre sua carreira (McMILLAN, 2005). Segundo Velloso e Cardoso (2008), à época dos esforços iniciais de fundação da Universidade de Brasília já se considerava a possibilidade de um ciclo básico capaz de adiar a escolha da carreira para depois da conclusão de algumas disciplinas introdutórias.

Apesar de evidências de que o estudante que ingressa no curso realmente desejado está menos propenso à evasão de curso (McMILLAN, 2005), o ingresso em cursos superiores pode ter natureza oportunista. Mesmo não almejando determinado curso, o estudante ingressa nele como "trampolim" ao curso realmente pretendido (BRASIL, 1996). Desse modo, visando em algum momento migrar para o curso de real interesse, o estudante pode acabar optando por ingressar em algum curso similar, menos concorrido e, consequentemente, de ingresso mais fácil (DIAS; THEÓPHILO; LOPES, 2010).

O ingresso intencional em curso indesejado para posterior troca a outro realmente pretendido já foi relatado há quase duas décadas pela Comissão Especial de Estudos sobre Evasão (BRASIL, 1997). Apesar de não ser um fenômeno recente, dificilmente a literatura explora essa questão explicitamente, a exemplo do estudo de Cunha, Tunes e Silva (2001) o qual denomina esse tipo de ingresso como "ponte de acesso". Vale salientar que nem sempre o ingresso em curso não pretendido é intencional ou oportunista. Em estudo francês, Dubet (2004) constatou que alunos menos privilegiados socialmente acabam ingressando em cursos menos prestigiados.

As evidências do estudo de Nogueira (2004) sugerem que a escolha do curso superior pode ocorrer com base na análise da carga exigida de estudos dele. Esse autor registrou casos de estudantes que, ao almejarem somente o título de graduado, escolhem cursos que, na visão deles, possuem cargas amenas de estudo. Dessa maneira, tais estudantes tendem a mudar de curso superior quando as expectativas não são concretizadas (NOGUEIRA, 2004). Não obstante, o 
rendimento acadêmico insatisfatório em determinado curso pode influenciar o estudante a buscar outra formação ou até mesmo abandonar o sistema de ensino superior, devido à perda do sentimento de autoconfiança (FIEGEHEN, 2006; MEYER; MARX, 2014).

Outro fator que pode influenciar a escolha de estudantes por determinado curso é a relevância dada ao mercado de trabalho em termos de emprego e carreira (HOTZA; LUCCHIARI, 1998; MCMILLAN, 2005; MARINGE, 2006). A escolha do curso de graduação pelo estudante é influenciada, de certa maneira, pelo potencial de inserção dele no mercado de trabalho (BRITO, 2013). Dessa forma, o estudante tende a escolher profissões em que há promissoras oportunidades na carreira (MARINGE, 2006).

$O$ estudante tende a analisar não somente o mercado de trabalho do curso escolhido, mas também faz um comparativo com as demais carreiras (McMILLAN, 2005). Como exemplo, Brito (2013) atribui a evasão de cursos de licenciaturas à desvalorização das carreiras docentes. Entre estudantes que migram de curso, a busca por formação profissional voltada à empregabilidade foi a razão mais expressiva apontada pelos participantes do estudo de Hotza e Lucchiari (1998).

Hotza e Lucchiari (1998) criticam essa postura do estudante em reduzir a universidade a uma escola profissionalizante, pressupondo que o principal objetivo da universidade seja formar mão de obra qualificada para o mercado de trabalho. Por outro lado, criticando o sistema de ensino superior, Dubet (2004) alerta para a existência de cursos que são, por natureza, totalmente desvinculados do mercado de trabalho e os desaprova argumentando que funcionam "como maneiras de armazenar os jovens no ensino como alternativa ao desemprego" (DUBET, 2004, p. 549).

Corroborando com Dubet (2004), Di Pietro (2007), em estudo empírico, verificou que à medida que 0 jovem egresso do ensino médio não possui qualificações suficientes ao mercado de trabalho, ele vislumbra a universidade como a melhor alternativa ao desemprego. Ser estudante soa socialmente melhor que estar desempregado (DI PIETRO, 2007). Em suma, pode-se dizer que a ausência de atratividade do mercado de trabalho do curso superior escolhido pelo aluno pode influenciá-lo a buscar outros cursos (DIAS; THEÓPHILO; LOPES, 2010). 
O nível de formação acadêmica dos pais exerce bastante influência sobre a educação dos filhos: quanto maior o grau de instrução dos pais, menor a probabilidade de o filho abandonar o ensino superior (Di PIETRO; 2007). Se por um lado parece fundamental o apoio familiar na continuidade da formação acadêmica (TINTO, 1973), por outro, percebe-se que a influência de familiares e amigos também pode incidir como determinante para o abandono de uma carreira por outra (ANDRIOLA; ANDRIOLA; MOURA, 2006). É apresentada no quadro 1 uma síntese dos motivos que influenciam a mudança de curso, à luz da literatura acima discutida.

Quadro 1 Síntese dos motivos que influenciam a mudança de curso

\begin{tabular}{|l|l|}
\hline Motivos que levam à Mudança de Curso & \multicolumn{1}{|c|}{ Referências } \\
\hline $\begin{array}{l}\text { Desconhecimento dos cursos e carreiras } \\
\text { profissionais }\end{array}$ & $\begin{array}{l}\text { Hotza e Lucchiari (1998); Magalhães e Redivo } \\
\text { (1998); McMillan (2005); Bardagi; Hutz, (2009). }\end{array}$ \\
\hline $\begin{array}{l}\text { Ausência de suporte vocacional ou } \\
\text { orientação profissional }\end{array}$ & $\begin{array}{l}\text { Hotza e Lucchiari (1998); Andriola, Andriola e Moura } \\
\text { (2006); Dias, Theóphilo e Lopes (2010). }\end{array}$ \\
\hline Ingresso precoce no ensino superior & $\begin{array}{l}\text { Brasil (1997); Magalhães e Redivo (1998); McMillan } \\
\text { (2005); Oquendo (2008); Bardagi e Hutz (2009); } \\
\text { Reis, Cunha Spritzer (2012) }\end{array}$ \\
\hline $\begin{array}{l}\text { Ingresso em curso indesejado / Efeito } \\
\text { Trampolim ou Ponte de Acesso }\end{array}$ & $\begin{array}{l}\text { Brasil (1997); Cunha, Tunes e Silva (2001); McMillan } \\
\text { (2005); Dias, Theóphilo e Lopes (2010) }\end{array}$ \\
\hline Carga de estudos do curso & Nogueira (2004) \\
\hline $\begin{array}{l}\text { Falta de atratividade do mercado de } \\
\text { trabalho do curso }\end{array}$ & $\begin{array}{l}\text { Hotza e Lucchiari (1998); McMillan (2005), Maringe } \\
\text { (2006), Dias, Theóphilo e Lopes (2010); Brito (2013) }\end{array}$ \\
\hline Influência de familiares e amigos & Di Pietro (2007); Andriola; Andriola e Moura (2006 \\
\hline Rendimento acadêmico insatisfatório & Fiegehen (2006); Meyer e Marx (2014) \\
\hline Frustração com o curso & $\begin{array}{l}\text { Brasil (1997); Gouveia et. al(1994); Dulliius e Cyrne } \\
\text { (2010) }\end{array}$ \\
\hline
\end{tabular}

\subsection{As regras para a transferência interna de alunos nas IES}

Nessa seção serão explicitadas as regras adotadas nos editais de transferência interna de algumas Instituições de Ensino Superior - IES do país, conforme levantamento nos editais de transferência interna disponíveis nas páginas eletrônicas de cada instituição. A escolha delas deu-se pela posição destacada recebida pelo Ranking das Universidades do Brasil ${ }^{1}$.

\footnotetext{
${ }^{1}$ http://ruf.folha.uol.com.br/2016/ranking-de-universidades/
} 


\subsubsection{A transferência interna de alunos na Universidade de Brasília}

As mudanças de curso na Universidade de Brasília, denominadas nesse estudo como transferências internas, são regulamentadas pela Resolução do Conselho de Ensino, Pesquisa e Extensão - CEPE/UnB n. 138/2010. Em seu art. 10, essa Resolução define mudança de curso como "autorização dada ao estudante regular de graduação para ter alterado o vínculo com seu curso de ingresso na Universidade para um curso de sua escolha".

As vagas ofertadas nos editais destinadas à transferência interna para o semestre $(n)$ de um ano letivo são oriundas das vagas ociosas geradas no semestre anterior (n-1). A cada semestre um edital é publicado informando os requisitos, regras, quantitativo de vagas de cada curso e turno. A mudança de curso é realizada por meio de processo seletivo interno regido por edital, sem a necessidade de realização de provas de seleção.

Para solicitar a transferência interna de curso de graduação, o aluno regularmente matriculado na UnB deve haver cumprido, cumulativamente, dois requisitos gerais como condições de admissibilidade: i) haver cursado disciplinas, podendo ser obrigatórios ou optativas, do curso pretendido no total de 24 créditos e ii) ter integralizado as disciplinas constantes dos dois primeiros períodos da grade curricular do curso de origem. Caso o curso requeira prova de habilidade específica, o aluno deve apresentar comprovante de habilitação.

Entre as restrições observadas nos editais, o candidato não pode estar usufruindo de Trancamento Geral de Matrícula - TGM no período de solicitação, tampouco pode estar na condição de provável formando no semestre seguinte. Ademais, a depender da forma de ingresso no curso de graduação de origem, o candidato fica impedido de concorrer às vagas de mudança de curso, tais como: seleção entre portadores de diploma de curso superior - DCS e beneficiários de convênio, acordo cultural, cortesia diplomática, duplo curso, condição de refugiado, transferência obrigatória e facultativa, bem como alunos já contemplados com transferência interna anteriormente.

A forma de seleção entre os candidatos é norteada por uma fórmula matemática que pondera o quantitativo de créditos cursados nas disciplinas obrigatórias ( $\mathrm{Ci}$ ) e nas disciplinas optativas ( $\mathrm{Di}$ ) do curso pretendido pelas 
respectivas menções alcançadas nelas $(\mathrm{Pi})$. Os pesos são distribuídos entre as menções da seguinte forma:

Quadro 2 Ponderação utilizada na fórmula da mudança de curso

\begin{tabular}{|l|c|c|c|}
\hline \multicolumn{1}{|c|}{ Menção } & Sigla & $\begin{array}{c}\text { Equivalência } \\
\text { numérica }\end{array}$ & $\begin{array}{c}\text { Peso na Média } \\
\text { Ponderada (MP) }\end{array}$ \\
\hline Superior & SS & 9,0 a 10,0 & 5 \\
\hline Médio Superior & MS & 7,0 a 8,9 & 4 \\
\hline Médio & MM & 5,0 a 6,9 & 3 \\
\hline Médio Inferior & MI & 3,0 a 4,9 & 2 \\
\hline Inferior & II & 0,1 a 2,9 & 1 \\
\hline Sem Rendimento & SR & zero & 0 \\
\hline
\end{tabular}

As disciplinas obrigatórias possuem maior peso em relação às optativas, conforme normatizado pelo art. 1ํㅜㄹ inciso IV, alínea "a" da Resolução CEPE/UnB n. 138/2010:

$$
\text { Média Ponderada }=\frac{1,6 \sum \mathrm{CiPi}+\sum \mathrm{DiPi}}{\sum \mathrm{Ci}+\sum \mathrm{Di}}
$$

Nos editais analisados, a média ponderada mínima necessária para habilitação ao processo de mudança de curso foi de $3(\mathrm{MP} \geq 3$ ). Havendo empate, seleciona-se, primeiramente, o candidato com maior soma de créditos de disciplinas alcançados no curso pretendido e, persistindo o empate, considera-se o Índice de Rendimento Acadêmico - IRA. Foram analisados 9 editais de transferência interna englobando desde o publicado no 1\%/2012 ao 1\%/2016. Esse recorte temporal justifica-se pela disponibilidade dos dados pela Secretaria de Administração Acadêmica - SAA da Universidade de Brasília até o momento da realização desse estudo.

O não atendimento dos requisitos listados implica em eliminação do candidato do processo de mudança de curso. É válido ressaltar também que a partir do segundo semestre de 2015 começou a ser cobrada taxa de inscrição. Por fim, a classificação dos habilitados à transferência interna é realizada por ordem decrescente das médias ponderadas (MP) obtidas pelos candidatos em conformidade com a quantidade de vagas destinadas a cada turno de curso. 


\subsubsection{A transferência interna de alunos em outras universidades}

As universidades públicas brasileiras são, de modo geral, autônomas para deliberarem acerca das regras de mudança interna de curso. Nesta seção, são apresentadas as principais normas e medidas adotadas pelas principais universidades brasileiras de cada região geográfica do país, conforme o Ranking das Universidades do Brasil - RUF de $2016^{2}$. Realizou-se uma varredura nos últimos editais de mudança de curso publicados nas páginas institucionais dessas universidades. Ao final da seção é apresentado um quadro comparativo da adoção das regras e normas levantadas nos editais pelas universidades pesquisadas.

Na Universidade Federal do Rio de Janeiro - UFRJ ${ }^{3}$, a mudança interna de curso é realizada via processo seletivo em que os alunos são submetidos à realização de prova de caráter eliminatório e classificatório versando sobre os conteúdos curriculares das matérias dos semestres iniciais do curso de destino. Uma vez classificado, o aluno não mais pode desistir da vaga conquistada. Como requisito de admissibilidade para participar do processo seletivo, é necessário que o aluno tenha um mínimo de matérias cursadas com aproveitamento do curso de origem e ter um mínimo de créditos de equivalência de conteúdo com o curso pleiteado.

Na Universidade de São Paulo - USP ${ }^{4}$, a mudança de curso é regulamentada por meio de Resolução. As vagas são destinadas a estudantes que pretendem mudar de curso, oriundos de qualquer instituição de ensino superior, inclusive a USP. O processo seletivo é subdividido em duas fases: pré-seleção e seleção propriamente dita. A pré-seleção é realizada por intermédio de aplicação de provas com conteúdo da área em que o curso de destino está englobado. Essas áreas são Humanidades, Ciências Exatas e Ciências Biológicas.

No edital consultado, estavam explícitas a exigência de pagamento de taxa de inscrição, assim como a indicação de apenas um curso. Classificados em ordem decrescente de notas na pré-seleção, os candidatos são selecionados, dentro do número de vagas, pelas diversas unidades da USP.

\footnotetext{
2 http://ruf.folha.uol.com.br/2016/

3 http://acessograduacao.ufrj.br/images/ Acesso-2016/2016 1-Editais/2016 1-Edital 18-2016-MCMCP.pdf

4 http://www.prg.usp.br/wp-content/uploads/Resolu\%C3\%A7\%C3\%A3o-CoG-7045-de-2015.pdf
} 
$\mathrm{Na}$ Universidade Federal de Minas Gerais - UFMG ${ }^{5}$, o processo seletivo de reopção de curso é destinado apenas a alunos internos. No edital consultado, era permitida apenas a indicação de um curso no ato de pedido de mudança de curso. Uma vez conseguida, não é mais facultado ao aluno a mudança de curso via edital de transferência interna. Na Universidade Federal do Paraná - UFPR ${ }^{6}$ é admitida apenas uma inscrição por aluno. Não há aplicação de provas, tampouco a cobrança de taxas. O critério de seleção baseia-se na comprovação via histórico escolar de maior carga horária integralizada, sendo o critério de desempate o menor número de reprovações.

$\mathrm{Na}$ Universidade Federal do Rio Grande do SUL - UFRGS ${ }^{7}$, assim como na USP, as vagas são disputadas tanto por candidatos já aluno da UFRGS quanto por candidatos que pretendem ingressar na universidade via ingresso por transferência externa. Há cobrança de taxa e cada candidato somente pode realizar uma inscrição. Os candidatos são submetidos a provas eliminatórias de seleção que contemplam assuntos pertinentes ao curso pretendido e redação. Não sendo eliminado, o candidato será classificado em ordem decrescente de nota.

$\mathrm{Na}$ Universidade Federal do Ceará - UFC ${ }^{8}$, o processo seletivo de mudança de curso é composto de duas etapas: análise de pré-requisitos de elegibilidade e análise de mérito acadêmico. Assim como na UnB, não há realização de provas, sendo que o mérito acadêmico corresponde ao desempenho do aluno nas disciplinas cursadas no curso de origem. Há uma bonificação na nota para alunos que optam pela mudança de curso dentro de uma mesma Unidade Acadêmica. Admite-se apenas uma opção de curso por candidato no ato da inscrição.

$\mathrm{Na}$ Universidade Federal de Santa Catarina - UFSC ${ }^{9}$ a transferência interna também é concedida apenas uma vez e as solicitações não requerem pagamento de taxas. Em geral, os colegiados de cada curso de graduação da UFSC estabelecem, por meio de Portarias, as regras para admissão das solicitações de transferência interna. Não há uma padronização. $O$ quadro 3 elenca as normas e medidas adotadas nos processos seletivos de mudança de curso das universidades brasileiras pesquisadas, realizando um comparativo entre elas. As células assinaladas significam que a referida universidade adota a respectiva norma ou

\footnotetext{
${ }^{5} \mathrm{https}$ ://www2.ufmg.br/drca/drca/Home/Graduacao/Reopcao-de-Curso/Regulamento-2016

${ }_{6}^{6} \mathrm{http}: / /$ www.prograd.ufpr.br/portal/provar/wp-content/uploads/sites/11/2015/07/Edital-inscri\%C3\%A7\%C3\%A3o-reop\%C3\%A7\%C3\%A3o-1.pdf

${ }^{7} \mathrm{http}: / /$ www.ufrgs.br/coperse/processos-seletivos/extra/2008-2/manual-do-candidato/primeira-parte-transferencia-interna-e-voluntaria

${ }^{8} \mathrm{http}: / /$ www.prograd.ufc.br/images/files/editais_resultados/2015/edital_27/edital_027_2015_mudanca_de_curso_2016_1.pdf
} 
medida, ao passo que as células em branco indicam que a universidade não adota a norma ou medida ou que não estava explícito no edital.

Quadro 3 Síntese das regras de mudança de curso em outras universidades

\begin{tabular}{|c|c|c|c|c|c|c|c|}
\hline \multirow{4}{*}{$\begin{array}{c}\text { Categorização das principais normas } \\
\text { e medidas adotadas pelas IES } \\
\text { pesquisadas }\end{array}$} & \multicolumn{7}{|c|}{ Universidades brasileiras públicas pesquisadas } \\
\hline & UFRJ & USP & UFMG & UFPR & UFRGS & UFC & UFSC \\
\hline & \multicolumn{7}{|c|}{ Ano de publicação do edital consultado: } \\
\hline & 2016 & 2016 & 2016 & 2017 & 2016 & 2016 & 2016 \\
\hline Submissão a provas & $\mathrm{X}$ & $\mathrm{X}$ & & & $\mathrm{X}$ & & \\
\hline Cobrança de taxa de inscrição & & $\mathrm{X}$ & & & $\mathrm{X}$ & & \\
\hline $\begin{array}{l}\text { Concessão de bonificação entre } \\
\text { cursos de mesma área de } \\
\text { conhecimento }\end{array}$ & & & & & & X & \\
\hline Opção por apenas um curso & X & $\mathrm{X}$ & X & $X$ & $\mathrm{X}$ & $\mathrm{X}$ & X \\
\hline Solicitação irreversível & X & X & - & $X$ & & & \\
\hline $\begin{array}{l}\text { Vagas destinadas à mudança de } \\
\text { curso e à transferência externa }\end{array}$ & & X & & & $\mathrm{X}$ & & \\
\hline
\end{tabular}

Fonte: elaboração própria a partir dos editais consultados 


\section{MÉTODOS E TÉCNICAS DE PESQUISA}

Neste capítulo, apresenta-se a abordagem metodológica adotada no estudo, sendo constituída pela descrição geral da pesquisa, a caracterização dos elementos de redes utilizados, descrição dos programas utilizados e dos pressupostos estatísticos de análise.

\subsection{Tipo e Descrição Geral da Pesquisa}

A classificação de uma pesquisa acadêmica é geralmente feita com base no objetivo geral proposto por ela (GIL,1999). Dessa forma, no intuito de descrever como são estabelecidas as transferências internas de alunos entre os cursos de graduação na Universidade de Brasília, trata-se de uma pesquisa descritiva que, por sua natureza, busca retratar "características de determinada população ou fenômeno ou o estabelecimento de relações entre variáveis" (GIL, 1999, p. 44).

A caracterização da rede de transferências internas de alunos entre cursos de graduação deu-se, sobremodo, por meio da identificação das propriedades da rede e da verificação das mudanças de cursos entre as áreas de conhecimento. Ademais, procedeu-se à investigação do efeito trampolim nos fluxos de transferência interna de alunos entre os cursos de graduação, isto é, a existência de movimento migratório de cursos menos para cursos mais concorridos nos exames vestibulares da UnB.

É válido salientar que ao se pretender uma nova visão do fenômeno das transferências internas de alunos entre cursos de graduação por meio da abordagem de análise de redes sociais, esse estudo aproxima-se também, por esse motivo, do nível de pesquisa exploratória, conforme salienta Gil (1999). Recorreu-se à abordagem quantitativa para se analisar os dados secundários relativos às transferências internas de alunos entre cursos de graduação na Universidade de Brasília do período do 1\%/2012 ao 1\%/2016.

$O$ delineamento do objetivo geral deu-se por meio de três etapas, traduzidas em objetivos específicos. A fim de alcançar os objetivos propostos, 
empregou-se método quantitativo apoiado sobre análise de redes sociais. As análises apoiaram-se em métricas e propriedades de redes, como: grau, grau médio, densidade, distribuição de grau, intermediação, análise de faç̧ão e de clusters. O quadro 4 apresenta uma esquematização dos objetivos do estudo, bem como as estratégias metodológicas adotadas a fim de alcançá-los.

Quadro 4 Objetivos específicos e metodologia de análise utilizada

\begin{tabular}{|c|c|}
\hline & Metodologia Adotada \\
\hline $\begin{array}{l}\text { OBJETIVO ESPECÍFICO 1: } \\
\text { Identificar as propriedades da rede de transferência } \\
\text { interna e como são estabelecidas as mudanças de curso } \\
\text { e seus reflexos no fluxo entre os turnos e entre os campi } \\
\text { da UnB }\end{array}$ & $\begin{array}{l}\text { - Métricas de centralidade de } \\
\text { rede: grau de centralidade, } \\
\text { distribuição de grau, } \\
\text { densidade e centralidade de } \\
\text { intermediação. }\end{array}$ \\
\hline OBJETIVO ESPECÍFICO 2: & \\
\hline $\begin{array}{l}\text { Verificar como ocorrem as transferências internas entre as } \\
\text { áreas de conhecimento e a (des)necessidade de } \\
\text { mecanismos de bonificação. }\end{array}$ & - Subgrupos e Análise faccional \\
\hline OBJETIVO ESPECÍFICO 3: & \\
\hline $\begin{array}{l}\text { Investigar o efeito trampolim nos fluxos de transferência } \\
\text { interna entre os cursos de graduação. }\end{array}$ & - Análise de Cluster \\
\hline
\end{tabular}

\subsection{Definição Operacional dos Elementos da Rede de Transferência Interna}

Conforme salientado por Newman (2003), os vértices de uma rede social podem ter diversas significações. No presente estudo, os vértices da análise de rede representaram os cursos de graduação da Universidade de Brasília que registraram fluxo de entrada ou de saída de alunos por motivo de reopção interna de curso. Ao todo, 92 cursos de graduação foram considerados no presente estudo, inteirando 1.050 transferências internas via editais.

Quanto às arestas, consoante Newman (2003), elas podem significar laços afetivos, contatos profissionais, proximidades geográficas, entre outras coisas. No presente estudo elas simbolizam os fluxos de ingresso ou de saída de alunos regulares nos cursos de graduação da UnB. Conforme explicitado, as arestas podem ser direcionadas, quando unidirecionais, ou nãodirecionadas, quando bidirecionais. No presente estudo, as arestas foram consideradas como direcionadas.

É sabido que a classificação e sistematização das áreas do conhecimento pelos órgãos governamentais possuem finalidade metódica e prática (BRASIL, 2016). De modo geral, o intuito é proporcionar às instituições 
de pesquisa, ensino e inovação uma maneira estruturada de prestação de informações acerca de projetos de pesquisa e recursos humanos (MEC, 2016). Atualmente, as áreas do conhecimento são subdivididas em 9 classificações: Ciências Exatas e da Terra; Ciências Biológicas; Engenharias; Ciências da Saúde; Ciências Agrárias; Ciências Sociais Aplicadas; Ciências Humanas; Linguística, Letras e Artes; Multidisciplinar (BRASIL, 2016).

Dessa forma, considerando-se a classificação como flexível, os cursos de graduação foram subdivididos, para fins do presente estudo, em 3 grandes áreas de conhecimento: Ciências Agrárias e Exatas; Ciências Humanas, Letras e Artes; Ciências Biológicas e da Saúde. As adaptações realizadas e a classificação dos cursos entre elas são informadas no quadro 5.

\begin{tabular}{|c|c|c|}
\hline \multicolumn{2}{|r|}{$\begin{array}{l}\text { Áreas de } \\
\text { Conhecimento } \\
\text { adaptadas }\end{array}$} & Cursos de graduação participantes do estudo \\
\hline 1 & $\begin{array}{l}\text { Ciências Agrárias, } \\
\text { Exatas e } \\
\text { Engenharias }\end{array}$ & $\begin{array}{l}\text { Agronomia, Ciências Ambientais, Ciência da Computação, Computação, } \\
\text { Engenharia, Engenharia Aeroespacial, Engenharia Ambiental, Engenharia } \\
\text { Automotiva, Engenharia Civil, Engenharia da Computação, Engenharia } \\
\text { Elétrica, Engenharia Eletrônica, Engenharia de Energia, Engenharia } \\
\text { Florestal, Engenharia Mecânica, Engenharia Mecatrônica, Engenharia de } \\
\text { Produção, Engenharia Química, Engenharia de Redes de Comunicação, } \\
\text { Engenharia de Software, Estatística, Física, Geologia, Gestão do } \\
\text { Agronegócio, Gestão Ambiental, Matemática, Ciências Naturais, Química, } \\
\text { Química Tecnológica, Medicina Veterinária. }\end{array}$ \\
\hline II & $\begin{array}{l}\text { Ciências } \\
\text { Humanas, Letras } \\
\text { e Artes }\end{array}$ & $\begin{array}{l}\text { Administração, Arquivologia, Biblioteconomia, Ciências Contábeis, Artes } \\
\text { Cênicas, Design, Direito, Ciências Econômicas, Comunicação Social, } \\
\text { Arquitetura e Urbanismo, Filosofia, Geografia, Gestão de Políticas Públicas, } \\
\text { História, Letras Espanhol, Letras Inglês, Letras, Música Museologia, } \\
\text { Pedagogia, Artes Plásticas, Ciência Política, Relações Internacionais, } \\
\text { Serviço Social, Ciências Sociais, Teoria Crítica e História da Arte, Turismo }\end{array}$ \\
\hline III & $\begin{array}{l}\text { Ciências } \\
\text { Biológicas e da } \\
\text { Saúde }\end{array}$ & $\begin{array}{l}\text { Ciências Biológicas, Biotecnologia, Educação Física, Enfermagem, } \\
\text { Farmácia, Fisioterapia, Fonoaudiologia, Gestão de Saúde Coletiva, } \\
\text { Medicina, Nutrição, Odontologia, Psicologia, Saúde Coletiva, Terapia } \\
\text { Ocupacional. }\end{array}$ \\
\hline
\end{tabular}

Quadro 5 Classificação dos cursos nas áreas de conhecimentos adotadas

Fonte: Elaboração própria

\subsection{Tipos e Coleta de Dados}

Os dados utilizados no presente estudo são de natureza secundária. Particularmente, o uso de dados secundários possuem algumas vantagens em relação aos dados primários em se tratando de estudos acerca de redes sociais (NEWMAN, 2004).

Segundo Newman (2004), estudos cuja metodologia adota entrevistas ou aplicação de questionários para a coleta de dados, além de trabalhosos, 
geralmente contam com a participação de algumas dezenas ou centenas de atores. Como consequência, a análise estatística é prejudicada. Ademais, os dados coletados costumam não ser numéricos (NEWMAN, 2004).

Não obstante, em estudos de redes em que são abordados relacionamentos subjetivos como, por exemplo, laços de amizades entre os atores, a interpretação do significado de amizade pode variar entre os respondentes, enviesando, portanto, os resultados do estudo (NEWMAN, 2004). Nesse estudo, os dados secundários referem-se a todas as transferências internas de curso realizadas por alunos de graduação entre 0 primeiro semestre de 2012 e o primeiro semestre de 2016. Tipicamente, há dois editais de transferência interna por ano, sendo um por semestre letivo. Ao todo, foram aprovadas 1.050 transferências internas no período dos 9 editais abordados.

As listagens dos alunos inscritos e contemplados com a transferência interna foram extraídas da página eletrônica da Secretaria de Administração Acadêmica - SAA da Universidade de Brasília - UnB. Considerando que essas listagens não informavam todos os dados de que as análises do presente estudo requeriam, assim como a presença de erros quanto ao nome, matrícula e por vezes até mesmo o curso de origem, foi solicitado ao Centro de Informática - CPD da UnB a disponibilização dos dados faltantes.

$O$ período de análise justifica-se pela acessibilidade às listagens de resultados de transferências internas da UnB. Na página eletrônica da instituição encontram publicados os editais e resultados a partir do primeiro semestre de 2012. Ademais, até a etapa de análise dos dados, em meados de agosto e setembro do ano de 2016, o resultado da mudança de curso referente ao segundo semestre de 2016 ainda não havia sido publicado.

Sendo assim, a partir do fato de que os dados utilizados nesse estudo podem ser determinados com precisão quanto à afiliação deles a determinada rede, diferentemente daqueles baseados em opiniões subjetivas como de amizade, logo eles podem ser considerados mais confiáveis (NEWMAN, 2004). 


\subsection{Tratamento, análise e interpretação dos dados}

As análises de redes foram realizadas por meio dos programas UCINET 6.0, desenvolvido por Borgatti, Everett e Freeman (2002), e NetDraw, desenvolvido por Borgatti (2002). O programa UCINET 6 é um programa baseado em matrizes voltado à análise e métricas de redes sociais, sendo o programa mais utilizado para isso (HUISMAN; DUIJN, 2012). No UCINET 6.0 propriamente dito não é possível a visualização de gráficos de redes, o que pode ser feito utilizando-se o programa NetDraw, que é voltado a isso (HUISMAN; DUIJN, 2012).

Antes da análise propriamente dita nesses programas, procedeu-se à tabulação dos dados com auxílio Microsoft Excel e, posteriormente, transferidos aos programas UCINET 6.0 e NetDraw. Conforme Prell (2012) esse é o procedimento recomendado quando se trabalha com matrizes de tamanho consideravelmente grande. Entre as facilidades proporcionadas pelo programa UCINET 6 está a compatibilidade com essa planilha eletrônica, além de disponibilizá-la no próprio programa (HUISMAN; DUIJN, 2012).

Para as análises pretendidas nos três primeiros objetivos específicos, foram considerados os alunos contemplados com vagas nas transferências internas, do primeiro semestre de 2012 ao primeiro de 2016. Sendo assim, o objeto de estudo são as 1.050 transferências internas ocorridas no período considerado.

A metodologia adotada a fim de se identificar as propriedades da rede de transferência interna e como são estabelecidas as mudanças de curso e seus reflexos no fluxo entre os turnos e entre os campi da UnB deu-se com o emprego de métricas de centralidade de redes, tais como o grau de centralidade, a distribuição de grau, densidade e intermediação.

Para se averiguar se as transferências internas ocorriam dentro das mesmas áreas de conhecimento, isto é, dentro das áreas de i) Ciências Agrárias, Exatas e Engenharias; ii) Ciências Humanas, Letras e Artes e iii) Ciências Biológicas e da Saúde, recorreu-se à análise de subgrupos por meio da abordagem de facções. Pretendeu-se averiguar se as mudanças de curso ocorriam de modo aleatório ou se obedecendo a determinados padrões, legitimando, assim, a (des)necessidade de mecanismos de bonificação. 
Por fim, no intuito de se investigar o efeito trampolim nos fluxos de transferência interna entre os cursos de graduação, realizou-se análise de cluster como recurso de verificação de similaridades entre os cursos de graduação. Depois de identificados os pares ou conjuntos de cursos mais similares, procedeu-se a pesquisa documental nos editais dos vestibulares do segundo semestre dos anos 2012, 2013, 2014 e 2015 a fim de categorizar os cursos conforme a demanda candidato por vaga. Na sequência, foi verificado se a transferência de um curso para outro era caracterizada pela transferência de um menos concorrido para um mais concorrido.

\subsection{Análise Faccional para Identificação de Subgrupos}

A análise faccional pode ser empregada na identificação de subgrupos dentro de uma aglomeração (EVERTON, 2012). Segundo Malhotra (2008, p. 573), esses subgrupos "são sugeridos pelos dados, e não definidos a priori". Todavia, por meio de análises exploratórias ou, até mesmo, pela análise visual da dispersão dos dados, o pesquisador pode especular arranjos ou quantidades de aglomerações (HANEMANN; RIDDLE, 2005; EVERTON, 2012).

Nesse sentido, a fim de identificar em qual quantidade de facções os elementos de uma rede ficam melhores alocados, os programas UCINET $6.0 \mathrm{e}$ NetDraw permitem que o pesquisador teste números arbitrariamente, em consonância com as características do objeto ou fenômeno estudado. Esse processo é realizado via algoritmo, o qual possui como finalidade selecionar os vértices mais parecidos e agrupá-los na expectativa de que tenham muitas conexões entre si e, idealmente, nenhuma conexão com aqueles diferentes (HANEMANN; RIDDLE, 2005; PRELL, 2012).

Ademais, o programa NetDraw é recomendado para esse tipo de análise por possuir, entre outros facilitadores de análise, o recurso visual de atribuir cores às diferentes facções que são criadas (EVERTON, 2012). Dessa forma, foram realizados testes exploratórios, em que "o pesquisador deve exercer julgamento e aplicar a intuição" (MALHOTRA, 2008, p. 575), no programa NetDraw pelo critério speed, a fim de identificar em qual quantidade de facções 
haveria o melhor ajustamento dos dados. A quantidade de facções testadas e os valores encontrados estão apresentados na tabela 1.

Tabela 1 Valores de ajustamento à quantidade de facções

\begin{tabular}{c|c}
\hline $\begin{array}{c}\text { Número desejado } \\
\text { de facções }\end{array}$ & $\begin{array}{c}\text { Valores de ajustamento } \\
\text { encontrados pelo NetDraw }\end{array}$ \\
\hline 03 & 2020.000 \\
\hline 04 & 1582.000 \\
\hline 05 & 1272.000 \\
\hline 06 & 1122.000 \\
\hline 07 & 1018.000 \\
\hline 08 & 942.000 \\
\hline 09 & 898.000 \\
\hline
\end{tabular}

O maior valor de ajustamento dos dados, em que a divisão faz correspondência com o estudo, refere-se ao quantitativo de três facções (2020.000). Havia expectativa em torno desse número, considerando-se o observado na etapa de depuração e tratamento dos dados: as mudanças de cursos ocorriam dentro das três grandes áreas de conhecimento.

Portando, com base nos resultados dos testes exploratórios, o número de facções adotadas no presente estudo foi igual a 3. Não obstante, mais do que o ajustamento dos dados, havia interesse em identificar quais os cursos de graduação estavam agrupados entre essas três facções, no intuito de identificar as transferências internas estavam adstritas às áreas de conhecimento.

\subsection{Análise de Cluster}

Uma vez obtida a rede de transferência interna e as métricas, assim como identificadas as facções entre os vértices que a compõem, realizou-se a análise de cluster no intuito de detectar quais as interações mais similares ou próximas entre si na rede. No contexto do presente estudo, essa análise pode fornecer indícios da existência de pares ou conjuntos de cursos de graduação que mais se relacionam, fornecendo, assim, maiores insumos às análises da rede de transferência interna da UnB no período analisado. A análise foi realizada com auxílio do método de Aglomeração Hierárquica de Johnson 
(JOHNSON'S HIERARCHICAL CLUSTERING), o qual adota algoritmos do tipo aglomerativos.

Pelo critério das similaridades, numa análise descendente, o algoritmo ordena os pares ou conjuntos de elementos conforme a diminuição dos níveis de similaridade. Supondo um conjunto $X$ (i, j) em que i e j representem cursos de graduação, se esses cursos são semelhantes, logo i e j são agrupados com valor alto. Por outro lado, se os cursos de graduação i e j são dissemelhantes, então são agrupados com valor baixo (BORGATTI; EVERETT; FREEMAN, 2002).

Entre os métodos de ligação ou encandeamento (LINKAGE METHODS), utilizou-se o método de análise da ligação média ou encadeamento médio (WTD_AVERAGE), pelo critério de similaridades. A escolha por esse método justifica-se pelo fato de que "o método do encadeamento médio utiliza informações sobre todos os pares de distâncias, e não apenas as distâncias mínimas ou máximas" e, por essa razão, "costuma ser preferido aos métodos de encadeamento único e de encadeamento completo" (MALHOTRA, 2008, p. 577). Formalizando o método da ligação média:

$$
\mathrm{d} \text { média }(\mathrm{A}, \mathrm{B})=\frac{1}{|\mathrm{~A}| *|\mathrm{~B}|} \sum_{\mathrm{i} \in \mathrm{A}, \mathrm{j} \in \mathrm{B}} \mathrm{d} \text { ij }
$$

em que dmédia $(A, B)$ é a distância média entre as aglomerações $A$ e $B$, dij é a distância entre os elementos $i$ e $j$ e $|\mathrm{A}|$ e $|\mathrm{B}|$ representam a quantidade de elementos das aglomerações A e B (MALHOTRA, 2008). 


\section{RESULTADOS E DISCUSSÃO}

\subsection{A rede de transferência interna da UnB}

Em conformidade com a definição de rede social adotada no estudo, os nós ou vértices representam cursos de graduação da Universidade de Brasília. Por seu turno, os cursos de graduação foram divididos, quando o caso, entre os turnos e entre os campi em que são ofertados. Por exemplo, o curso de Administração por ser ofertado tanto no turno diurno quanto no noturno foi contabilizado duas vezes. De mesmo modo, o curso de Enfermagem ofertado no campus Darcy Ribeiro foi representado por um vértice e Enfermagem ofertado no campus da Ceilândia por outro.

As setas ou arestas simbolizam a relação entre eles. Essa relação diz respeito ao fluxo de saída e de ingresso de alunos entre os cursos de graduação ocasionado pela transferência interna no período dos semestres 1\%/2012 ao 1\%/2016. Trata-se de interações unidirecionais. No total, foram identificados 92 vértices. Para melhor visualização e análise do gráfico de redes, foram criadas siglas para cada um.

A listagem dos cursos de graduação participantes do estudo, assim como as siglas criadas para representa-los, encontram-se na tabela 2, em ordem alfabética. Encontram-se também na tabela 2 informações acerca do número de alunos que saíram dos cursos de graduação (grau de saída) e o número de alunos que ingressaram neles (grau de entrada), via transferência interna, em números absolutos e em termos percentuais.

Tabela 2 Cursos que participaram da transferência interna

\begin{tabular}{l|l|r|r|r|r}
\hline \multicolumn{1}{c|}{ Cursos de Graduação } & \multicolumn{2}{c|}{ Sigla } & \multicolumn{2}{c|}{ Grau de Saída } & \multicolumn{2}{c}{ Grau de Entrada } \\
\hline Administração - Diurno & ADM-D & 10 & $0,95 \%$ & 9 & $0,86 \%$ \\
\hline Administração - Noturno & ADM-N & 2 & $0,19 \%$ & 37 & $3,52 \%$ \\
\hline Agronomia & AGR & 9 & $0,86 \%$ & 1 & $0,10 \%$ \\
\hline Arquitetura e Urbanismo - Diurno & FAU-N & 0 & $0,00 \%$ & 17 & $1,62 \%$ \\
\hline Arquitetura e Urbanismo - Noturno & FAU-D & 2 & $0,19 \%$ & 14 & $1,33 \%$ \\
\hline Arquivologia & ARQ & 3 & $0,29 \%$ & 14 & $1,33 \%$ \\
\hline
\end{tabular}


Continuação

\begin{tabular}{|c|c|c|c|c|c|}
\hline \multirow{2}{*}{$\begin{array}{l}\text { Cursos de Graduação } \\
\text { Artes Cênicas }\end{array}$} & \multirow{2}{*}{$\begin{array}{lr}\text { Sigla } \\
\text { CEN }\end{array}$} & \multicolumn{2}{|c|}{ Grau de Saída } & \multicolumn{2}{|c|}{ Grau de Entrada } \\
\hline & & 3 & $0,29 \%$ & 0 & $0,00 \%$ \\
\hline Artes Plásticas & PLAS & 21 & $2,00 \%$ & 8 & $0,76 \%$ \\
\hline Biblioteconomia & BIBLIO & 5 & $0,48 \%$ & 2 & $0,19 \%$ \\
\hline Biotecnologia & BIOTEC & 6 & $0,57 \%$ & 4 & $0,38 \%$ \\
\hline Ciência da Computação & $\mathrm{ClC}$ & 8 & $0,76 \%$ & 22 & $2,10 \%$ \\
\hline Ciências Ambientais & AMB & 3 & $0,29 \%$ & 1 & $0,10 \%$ \\
\hline Ciências Biológicas - Diurno & BIO-D & 11 & $1,05 \%$ & 13 & $1,24 \%$ \\
\hline Ciências Biológicas - Noturno & $\mathrm{BIO}-\mathrm{N}$ & 4 & $0,38 \%$ & 5 & $0,48 \%$ \\
\hline Ciências Contáveis - Diurno & CCA-D & 6 & $0,57 \%$ & 5 & $0,48 \%$ \\
\hline Ciências Contáveis - Noturno & CCA-N & 5 & $0,48 \%$ & 11 & $1,05 \%$ \\
\hline Ciências Econômicas & ECO & 14 & $1,33 \%$ & 37 & $3,52 \%$ \\
\hline Ciências Naturais & NAT & 17 & $1,62 \%$ & 0 & $0,00 \%$ \\
\hline Ciências Políticas & $\mathrm{POL}$ & 17 & $1,62 \%$ & 28 & $2,67 \%$ \\
\hline Ciências Sociais & $\mathrm{SOC}$ & 56 & $5,33 \%$ & 18 & $1,71 \%$ \\
\hline Computação & COMP & 17 & $1,62 \%$ & 4 & $0,38 \%$ \\
\hline Comunicação Social & FAC & 24 & $2,29 \%$ & 81 & $7,71 \%$ \\
\hline Design & DESIGN & 1 & $0,10 \%$ & 13 & $1,24 \%$ \\
\hline Direito - Diurno & DIR-D & 2 & $0,19 \%$ & 16 & $1,52 \%$ \\
\hline Direito - Noturno & DIR-N & 0 & $0,00 \%$ & 7 & $0,67 \%$ \\
\hline Educação Física & $\mathrm{EF}$ & 4 & $0,38 \%$ & 5 & $0,48 \%$ \\
\hline Enfermagem (Ceilândia) & ENF (CEI) - D & 0 & $0,00 \%$ & 11 & $1,05 \%$ \\
\hline Enfermagem (Darcy Ribeiro) & ENF (DR) - D & 17 & $1,62 \%$ & 5 & $0,48 \%$ \\
\hline Engenharia & ENG & 46 & $4,38 \%$ & 0 & $0,00 \%$ \\
\hline Engenharia Aeroespacial & ENG AERO & 2 & $0,19 \%$ & 7 & $0,67 \%$ \\
\hline Engenharia Ambiental & ENG AMB & 6 & $0,57 \%$ & 9 & $0,86 \%$ \\
\hline Engenharia Automotiva & ENG AUTO & 27 & $2,57 \%$ & 2 & $0,19 \%$ \\
\hline Engenharia Civil & ENG CIV & 8 & $0,76 \%$ & 24 & $2,29 \%$ \\
\hline Engenharia da Computação & ENG COMP & 15 & $1,43 \%$ & 14 & $1,33 \%$ \\
\hline Engenharia da Energia & ENG ENERG & 27 & $2,57 \%$ & 5 & $0,48 \%$ \\
\hline Engenharia de Produção & ENG PROD & 8 & $0,76 \%$ & 59 & $5,62 \%$ \\
\hline Eng. de Redes de Comunicação & ENG RED & 20 & $1,90 \%$ & 9 & $0,86 \%$ \\
\hline Engenharia de Software & ENG SOFT & 8 & $0,76 \%$ & 5 & $0,48 \%$ \\
\hline Engenharia Elétrica & ENG ELE & 11 & $1,05 \%$ & 50 & $4,76 \%$ \\
\hline Engenharia Eletrônica & ENG ELETRO & 28 & $2,67 \%$ & 5 & $0,48 \%$ \\
\hline Engenharia Florestal & ENG FLO & 8 & $0,76 \%$ & 5 & $0,48 \%$ \\
\hline Engenharia Mecânica & ENG MEC & 10 & $0,95 \%$ & 75 & $7,14 \%$ \\
\hline Engenharia Mecatrônica & ENG MECTRO & 26 & $2,48 \%$ & 10 & $0,95 \%$ \\
\hline Engenharia Química & ENG QUI & 9 & $0,86 \%$ & 16 & $1,52 \%$ \\
\hline Estatística & EST & 11 & $1,05 \%$ & 11 & $1,05 \%$ \\
\hline Farmácia (Ceilândia) - Diurno & FAR (CEI) - D & 4 & $0,38 \%$ & 6 & $0,57 \%$ \\
\hline Farmácia (Darcy Ribeiro) - Diurno & FAR (DR) - D & 5 & $0,48 \%$ & 0 & $0,00 \%$ \\
\hline Farmácia (Darcy Ribeiro) - Noturno & FAR (DR) - N & 3 & $0,29 \%$ & 1 & $0,10 \%$ \\
\hline Filosofia - Diurno & FIL-D & 13 & $1,24 \%$ & 2 & $0,19 \%$ \\
\hline
\end{tabular}




\begin{tabular}{|c|c|c|c|c|c|}
\hline Cursos de Graduação & Sigla & Grau & Saída & Grau d & ntrada \\
\hline Filosofia - Noturno & FIL-N & 2 & $0,19 \%$ & 0 & $0,00 \%$ \\
\hline Física - Diurno & FIS-D & 29 & $2,76 \%$ & 6 & $0,57 \%$ \\
\hline Física - Noturno & FIS-N & 12 & $1,14 \%$ & 2 & $0,19 \%$ \\
\hline Fisioterapia & FISIO & 10 & $0,95 \%$ & 6 & $0,57 \%$ \\
\hline Fonoaudiologia & FONO & 0 & $0,00 \%$ & 2 & $0,19 \%$ \\
\hline Geofísica & GEOFIS & 16 & $1,52 \%$ & 1 & $0,10 \%$ \\
\hline Geografia & GEO & 16 & $1,52 \%$ & 1 & $0,10 \%$ \\
\hline Geologia & GEOL & 0 & $0,00 \%$ & 22 & $2,10 \%$ \\
\hline Gestão Agronegócio (Darcy Ribeiro) & GEST AGR (DR) & 10 & $0,95 \%$ & 0 & $0,00 \%$ \\
\hline Gestão Agronegócio (Planaltina) & GEST AGR (PLA) & 2 & $0,19 \%$ & 0 & $0,00 \%$ \\
\hline Gestão Ambiental & GEST AMB & 1 & $0,10 \%$ & 2 & $0,19 \%$ \\
\hline Gestão de Políticas Públicas & GPP & 8 & $0,76 \%$ & 9 & $0,86 \%$ \\
\hline Gestão de Saúde Coletiva & GSC & 20 & $1,90 \%$ & 4 & $0,38 \%$ \\
\hline História - Diurno & HIST-D & 14 & $1,33 \%$ & 11 & $1,05 \%$ \\
\hline História - Noturno & HIST-N & 5 & $0,48 \%$ & 6 & $0,57 \%$ \\
\hline Letras - Diurno & LET-D & 73 & $6,95 \%$ & 14 & $1,33 \%$ \\
\hline Letras - Noturno & LET-N & 29 & $2,76 \%$ & 12 & $1,14 \%$ \\
\hline Letras Espanhol - Diurno & LET ESP - D & 0 & $0,00 \%$ & 1 & $0,10 \%$ \\
\hline Letras Espanhol - Noturno & LEST ESP - N & 16 & $1,52 \%$ & 2 & $0,19 \%$ \\
\hline Letras Inglês - Diurno & LET ING - D & 8 & $0,76 \%$ & 13 & $1,24 \%$ \\
\hline Letras Inglês - Noturno & LET ING - N & 1 & $0,10 \%$ & 0 & $0,00 \%$ \\
\hline Matemática - Diurno & MAT - D & 13 & $1,24 \%$ & 20 & $1,90 \%$ \\
\hline Matemática - Noturno & MAT - N & 10 & $0,95 \%$ & 7 & $0,67 \%$ \\
\hline Medicina & MED & 2 & $0,19 \%$ & 0 & $0,00 \%$ \\
\hline Medicina Veterinária & VET & 2 & $0,19 \%$ & 9 & $0,86 \%$ \\
\hline Museologia & MUSEO & 19 & $1,81 \%$ & 2 & $0,19 \%$ \\
\hline Música - Diurno & MUS-D & 0 & $0,00 \%$ & 1 & $0,10 \%$ \\
\hline Música - Noturno & MUS-N & 0 & $0,00 \%$ & 1 & $0,10 \%$ \\
\hline Nutrição & NUT & 1 & $0,10 \%$ & 16 & $1,52 \%$ \\
\hline Odontologia & ODONTO & 3 & $0,29 \%$ & 36 & $3,43 \%$ \\
\hline Pedagogia - Diurno & PEDAGO - D & 32 & $3,05 \%$ & 5 & $0,48 \%$ \\
\hline Pedagogia - Noturno & PEDAGO - $\mathrm{N}$ & 10 & $0,95 \%$ & 2 & $0,19 \%$ \\
\hline Psicologia & PSICO & 6 & $0,57 \%$ & 91 & $8,67 \%$ \\
\hline Química - Diurno & QUI-D & 6 & $0,57 \%$ & 4 & $0,38 \%$ \\
\hline Química - Noturno & QUI-N & 8 & $0,76 \%$ & 0 & $0,00 \%$ \\
\hline Química Tecnológica & QUI TEC & 12 & $1,14 \%$ & 1 & $0,10 \%$ \\
\hline Relações Internacionais & REL & 20 & $1,90 \%$ & 34 & $3,24 \%$ \\
\hline Saúde Coletiva & SAU COL & 16 & $1,52 \%$ & 0 & $0,00 \%$ \\
\hline Serviço Social - Diurno & SER-D & 26 & $2,48 \%$ & 0 & $0,00 \%$ \\
\hline Serviço Social - Noturno & SER-N & 8 & $0,76 \%$ & 1 & $0,10 \%$ \\
\hline Teoria Crítica e História da Arte & TCHA & 5 & $0,48 \%$ & 2 & $0,19 \%$ \\
\hline Terapia Ocupacional & TER OCU & 8 & $0,76 \%$ & 0 & $0,00 \%$ \\
\hline
\end{tabular}


Continuação

\begin{tabular}{|c|c|c|c|c|c|}
\hline Cursos de Graduação & Sigla & \multicolumn{2}{|c|}{ Grau de Saída } & \multicolumn{2}{|c|}{ Grau de Entrada } \\
\hline Turismo & TUR & 9 & $0,86 \%$ & 1 & $0,10 \%$ \\
\hline \multicolumn{2}{|l|}{ TOTAL } & 1.050 & $100 \%$ & 1.050 & $100 \%$ \\
\hline
\end{tabular}

Fonte: Elaboração própria a partir de dados da Universidade de Brasília.

O grau de saída corresponde ao somatório das interações que um determinado vértice possui com os demais (ALEJANDRO; NORMAN, 2005). No contexto desse estudo, trata-se da quantidade de alunos que renuncia determinado curso em troca de outro, via transferência interna. Assim, em termos de grau de saída, o maior valor registrado para a rede foi de 73 e o menor foi 0 , com média de 11,41. Esses números revelam que, entre o primeiro semestre de 2012 ao primeiro semestre de 2016, a maior quantidade de abandono de um curso por motivo de transferência interna foi de 73. Essas ocorrências foram registradas no curso de Letras (diurno), o qual foi seguido por Ciências Sociais e Engenharia (FGA) com, respectivamente, 56 e 46 abandonos.

Por sua vez, o grau de entrada representa o somatório das interações que os demais vértices possuem com o vértice em questão (ALEJANDRO; NORMAN, 2005). No contexto desse estudo, trata-se da quantidade de alunos recebidos via transferência interna por um determinado curso de graduação. $O$ maior valor registrado para o grau de entrada foi de 91 e o menor 0 , sendo a média 11,41. No período analisado, essa maior quantidade de ingressos registrada deu-se no curso de Psicologia, sendo seguido por Comunicação social e Engenharia Mecânica com valores de 81 e 75, respectivamente.

Sobre os procedimentos adotados para a construção da rede de transferência interna, são feitas as seguintes observações:

a. Sobre a posição e a distância entre os vértices, no algoritmo escolhido, os vértices com as menores distâncias entre si foram colocados mais próximos. Para que isso não levasse a dificuldades de visualização, recorreu-se às funcionalidades node repulsion (que separa vértices muito próximos um dos outros) e equal edge length (para distâncias equivalentes entre vértices adjacentes), conforme recomendado por Hanneman e Riddle (2005).

b. Quanto às relações direcionadas, elas podem ser ponderadas por meio da 
intensidade do fluxo de transferências de alunos entre cursos. Dessa forma, uma relação mais intensa significa um número maior de migração de alunos de um curso para outro, ao passo que uma relação menos intensa sugere uma menor migração entre cursos. Essa intensidade pode ser representada pela espessura das arestas que conectam os vértices da rede: quanto maior (menor) a intensidade das ligações, mais (menos) espessa a aresta.

c. Em relação ao tamanho dos vértices da rede de transferência interna, criou-se o indicador de resultado líquido - RL. Com intuito de verificar o saldo dos fluxos de transferência interna, unificou-se os quantitativos de saídas e de entradas nesse único indicador. Ou seja, o resultado líquido é a diferença entre o número de ingressos em determinado curso de graduação subtraída do número de saídas desse mesmo curso. Ou seja, resultado líquido = grau de entrada - grau de saída .

É válido salientar que esses resultados líquidos encontrados não permitem inferências acerca da taxa de sucesso, medida pelo número de formados num certo ano em relação ao número de ingressantes em anos anteriores, conforme tempo regular do curso (BRASIL, 1997), tampouco da taxa de retenção, que se refere à quantidade de alunos matriculados fora do prazo do curso pelo total de alunos matriculados (BRASIL, 1997). Além do mais, essas análises acerca da taxa de sucesso e retenção não fazem parte do escopo desse estudo. Em suma, não se pretendeu na pesquisa calcular índices de evasão ou retenção.

Tabela 3 Resultados Líquidos das migrações entre cursos

\begin{tabular}{l|c|l|c}
\hline \multicolumn{1}{c|}{ Cursos de Graduação } & RL & \multicolumn{1}{c|}{ Cursos de Graduação } & RL \\
\hline Psicologia & 85 & Ciências Ambientais & -2 \\
\hline Engenharia Mecânica & 65 & Farmácia (Darcy Ribeiro) - Noturno & -2 \\
\hline Comunicação Social & 57 & Filosofia - Noturno & -2 \\
\hline Engenharia de Produção & 51 & Gestão Agronegócio (Planaltina) & -2 \\
\hline Engenharia Elétrica & 39 & Medicina & -2 \\
\hline Administração - Noturno & 35 & História - Diurno & -3 \\
\hline Odontologia & 33 & Matemática - Noturno & -3 \\
\hline Ciências Econômicas & 23 & Engenharia de Software & -3 \\
\hline Geologia & 22 & Engenharia Florestal & -3 \\
\hline Arquitetura e Urbanismo - Diurno & 17 & Biblioteconomia & -3 \\
\hline Engenharia Civil & 16 & Teoria Crítica e História da Arte & -3 \\
\hline
\end{tabular}


Continuação

\begin{tabular}{|c|c|c|c|}
\hline Nutrição & 15 & Artes Cênicas & -3 \\
\hline Relações Internacionais & 14 & Fisioterapia & -4 \\
\hline Ciência da Computação & 14 & Farmácia (Darcy Ribeiro) - Diurno & -5 \\
\hline Direito - Diurno & 14 & Serviço Social - Noturno & -7 \\
\hline Arquitetura e Urbanismo - Noturno & 12 & Pedagogia - Noturno & -8 \\
\hline Design & 12 & Agronomia & -8 \\
\hline Ciências Políticas & 11 & Turismo & -8 \\
\hline Arquivologia & 11 & Química - Noturno & -8 \\
\hline Enfermagem (Ceilândia) & 11 & Terapia Ocupacional & -8 \\
\hline Matemática - Diurno & 7 & Física - Noturno & -10 \\
\hline Engenharia Química & 7 & Gestão Agronegócio (Darcy Ribeiro) & -10 \\
\hline Medicina Veterinária & 7 & Eng. de Redes de Comunicação & -11 \\
\hline Direito - Noturno & 7 & Filosofia - Diurno & -11 \\
\hline Ciências Contáveis - Noturno & 6 & Química Tecnológica & -11 \\
\hline Letras Inglês - Diurno & 5 & Enfermagem (Darcy Ribeiro) & -12 \\
\hline Engenharia Aeroespacial & 5 & Artes Plásticas & -13 \\
\hline Engenharia Ambiental & 3 & Computação & -13 \\
\hline Ciências Biológicas - Diurno & 2 & Letras Espanhol - Noturno & -14 \\
\hline Farmácia (Ceilância) - Diurno & 2 & Geofísica & -15 \\
\hline Fonoaudiologia & 2 & Geografia & -15 \\
\hline Gestão de Políticas Públicas & 1 & Engenharia Mecatrônica & -16 \\
\hline História - Noturno & 1 & Gestão de Saúde Coletiva & -16 \\
\hline Ciências Biológicas - Noturno & 1 & Saúde Coletiva & -16 \\
\hline Educação Física & 1 & Letras - Noturno & -17 \\
\hline Gestão Ambiental & 1 & Museologia & -17 \\
\hline Letras Espanhol - Diurno & 1 & Ciências Naturais & -17 \\
\hline Música - Diurno & 1 & Engenharia da Energia & -22 \\
\hline Música - Noturno & 1 & Física - Diurno & -23 \\
\hline Estatística & 0 & Engenharia Eletrônica & -23 \\
\hline Engenharia da Computação & -1 & Engenharia Automotiva & -25 \\
\hline Administração - Diurno & -1 & Serviço Social - Diurno & -26 \\
\hline Ciências Contáveis - Diurno & -1 & Pedagogia - Diurno & -27 \\
\hline Letras Inglês - Noturno & -1 & Ciências Sociais & -38 \\
\hline Biotecnologia & -2 & Engenharia & -46 \\
\hline Química - Diurno & -2 & Letras - Diurno & -59 \\
\hline
\end{tabular}

Fonte: Elaboração própria a partir de dados da Universidade de Brasília

$\mathrm{Na}$ sequência, o gráfico 1 ordena todos os cursos de modo decrescente em conformidade com os resultados líquidos encontrados. Ainda em relação aos valores de resultados líquidos encontrados, é válida uma observação. Conforme salientado, a quantidade de vagas destinadas à transferência interna na UnB resulta das vagas ociosas geradas no semestre imediatamente anterior. 
Gráfico 1 Ordenação dos cursos por resultado líquido

100

80

60

40

(1)

20

0

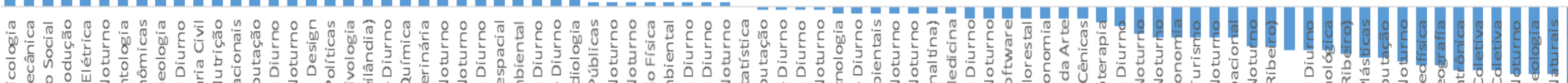

$-20$

$-40$
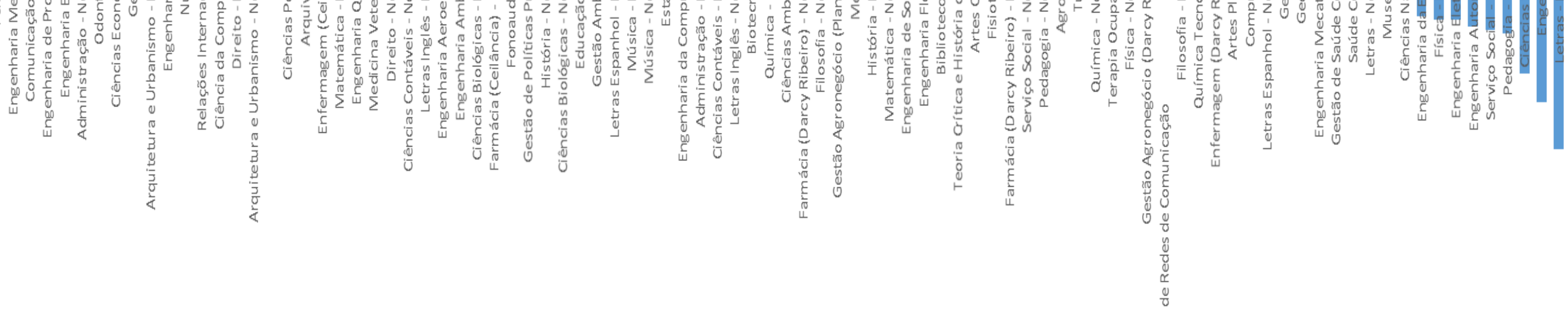

$-80$

Fonte: Elaboração própria a partir de dados da Universidade de Brasília. 
Assim, é natural que as quantidades ofertadas de vagas pelos cursos de graduação sejam diferentes. Nesse sentido, cita-se o caso de Medicina e Ciências Naturais, o exemplo mais ilustrativo. Figurando sempre como o curso com a maior relação candidato por vaga nos vestibulares da Universidade de Brasília, conforme evidenciado pelo anexo $A$, o curso de Medicina não ofertou vaga nos editais de transferência interna no período do 1/2012 ao 1\% 2016. Nesse período, apenas 2 alunos abandonaram a graduação em Medicina por outro curso, via transferência interna. Por outro lado, o curso de Ciências Naturais ofertou 195 vagas à transferência interna no mesmo período.

Apesar dessa quantidade expressiva, o que o coloca como um dos maiores ofertantes de vagas, conforme o anexo C, o curso de Ciências Naturais não figurou como destino de nenhum aluno que optou pela transferência interna, quer seja por falta de interessados por essa graduação, quer seja pelo o fato de não cumprimento por eles dos requisitos dos editais ou, ainda, não classificação deles dentro das vagas. Assim, apesar de Medicina e Ciências Naturais apresentarem o mesmo resultado líquido negativo, trata-se de situações bem distintas.

Outros cursos que, assim como Ciências Naturais, não registraram ingressos de alunos via transferência interna no período analisado, apesar da existência de vagas ofertadas nos editais, foram: Farmácia (Darcy Ribeiro), Filosofia (noturno), Gestão do Agronegócio (Darcy Ribeiro e FUP), Artes Cênicas, Saúde Coletiva, Química (noturno), Serviço Social (diurno) e Terapia Ocupacional.

Quanto aos cursos com os resultados líquidos negativos mais expressivos, esses cursos também apareceram entre os maiores ofertantes de vagas, em números acumulados no período analisado. Significa dizer que os resultados líquidos encontrados não se justificam por um possível grau de entrada baixo devido à pouca oferta de vagas, como é o caso, por exemplo, do curso de Medicina. Evidencia-se, dessa forma, que a inexpressividade de ingressos nesses cursos via transferência interna está ligada a outros fatores.

No intuito de ilustrar que o baixo quantitativo de ingresso em dados cursos de graduação não se explica pela possível quantidade baixa de oferta de vagas, 0 gráfico 2 faz um contraste entre o acumulado de vagas ofertadas nos editais de transferência interna (no eixo vertical), do período do 1\%/2012 ao 1\%/2016, e o quantitativo de ingressantes nos cursos de graduação via transferência interna 
nesse período (eixo horizontal) entre os cursos de graduação que obtiveram resultados negativos mais expressivos.

Gráfico 2 Vagas ofertadas nos editais e ingressos via transferências internas

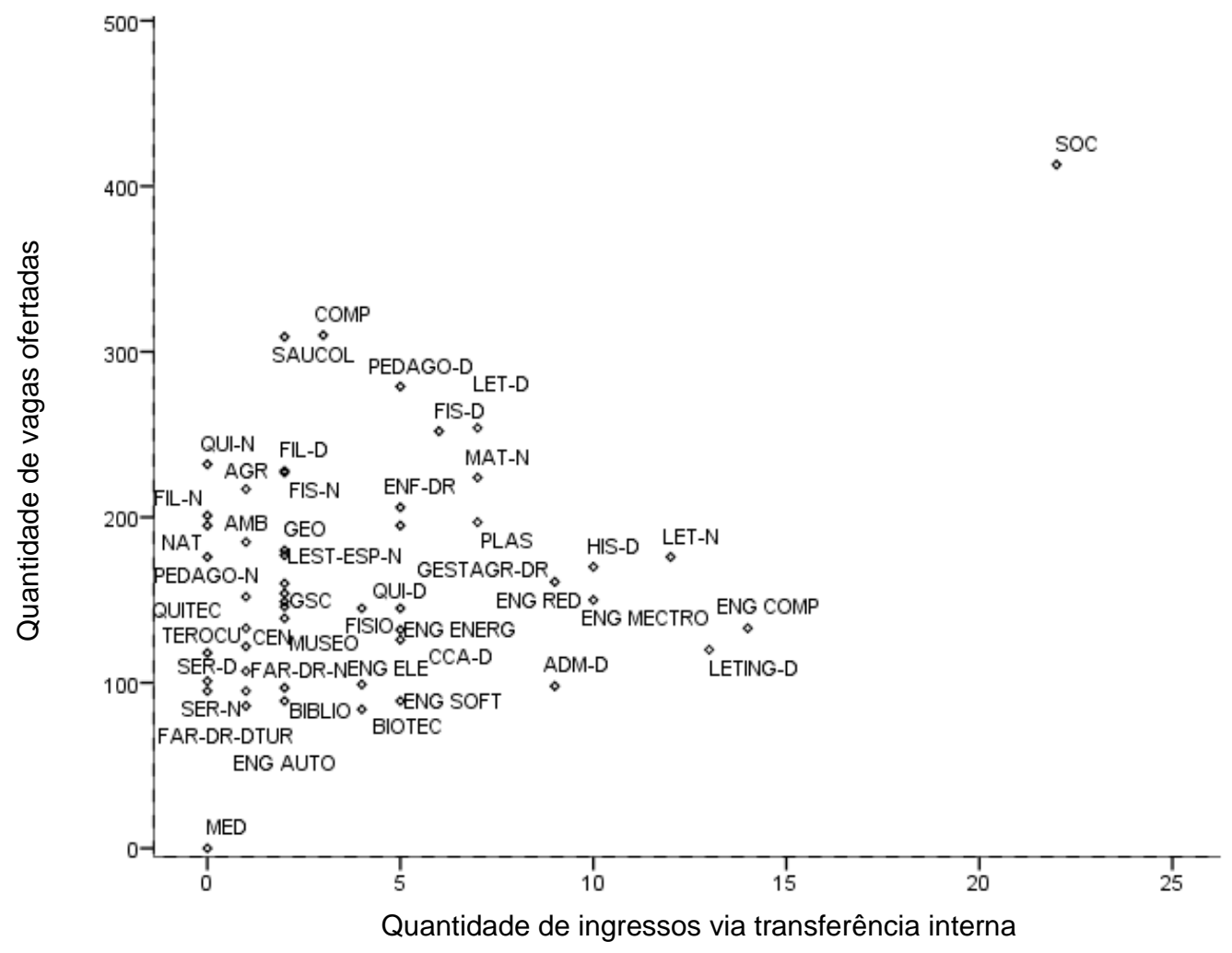

Fonte: Elaboração própria a partir de dados da Universidade de Brasília.

É válido sublinhar a posição do curso de Ciências Sociais, o mais destacado no gráfico de dispersão acima, a qual indica que a estratégia de preenchimento de vagas ociosas por meio de transferências internas não parece surtir efeitos consideráveis, sobremaneira, para esse curso. Com poucas exceções, percebe-se, de modo geral, a recorrência de oferta expressiva de vagas ociosas para preenchimento via transferência interna, conforme anexo $\mathrm{C}$.

Retomando-se a análise dos demais resultados líquidos, conforme gráfico 1, o curso de Psicologia lidera, sendo seguido por Engenharia Mecânica, Comunicação Social, Engenharia de Produção e Engenharia Elétrica. Entre os cursos com os menores resultados líquidos estão, em ordem decrescente: Serviço Social (diurno), Pedagogia (diurno), Ciências Sociais, Engenharia (FGA) e Letras (diurno). Mais uma 
vez, ressalta-se que o resultado líquido considera apenas a quantidade de ingressos e de saídas, sem levar em consideração o quantitativo de vagas ociosas que são ofertadas pelos cursos nos editais de transferência interna. $O$ quantitativo dessas vagas ociosas, quando ofertadas, variam de semestre para semestre.

Há uma aparente contradição quanto ao fato de haver uma engenharia entre os cursos com menores resultados líquidos, tendo em vista a presença significativa de outras engenharias entre os cursos com melhores resultados líquidos. A engenharia que consta entre os menores resultados líquidos é a ofertada no campus do Gama (FGA/UnB). Nesse campus, os semestres iniciais são voltados à formação básica de engenharia e, ao final desse ciclo básico, o aluno escolhe entre uma das seguintes especialidades: Aeroespacial, Automotiva, Energia, Eletrônica e Software.

Em consonância com os dados do estudo, percebeu-se uma significativa quantidade de registros de alunos que durante o ciclo básico, anterior à opção por alguma especialidade, optaram pela transferência interna. Analisando-se os fluxos de ingresso e saída entre os cursos de graduação, nota-se que, conforme será demonstrado adiante, há um nítido movimento, via transferência interna, da formação básica de engenharia do campus Gama (FGA/UnB) para outras engenharias ofertadas no campus Darcy Ribeiro.

Em comparação às causas amplamente publicadas na literatura de evasão nos cursos superiores de engenharia (CUNHA; SPRITZER; WILDHAGEN, 2012; MEYER; MARX, 2014), a transferência interna de uma engenharia para outra, no contexto desse estudo, parece estar mais relacionada à falta de identificação ou não atendimento da expectativa do aluno com a área cursada do que com possíveis dificuldades de aprendizado.

\subsection{Propriedades da rede de transferência interna da UnB}

\subsubsection{Distribuição de Grau}

Por meio de análise da distribuição de grau de saídas e de entradas das transferências internas, conforme ilustrado respectivamente nos gráficos 3 e 4 , é 
possível se perceber que majoritariamente os cursos de graduação se concentram nas faixas menos expressivas (de 0 a 20) tanto de saídas quanto de entradas.

No que concerne à distribuição do grau de saídas, no período analisado nesse estudo, em mais da metade dos cursos foram registrados até 30 abandonos por transferência interna. Por outro lado, as maiores quantidades de abandonos por essa modalidade foram registradas por apenas 4 cursos: Letras (diurno), Ciências Sociais, Engenharia (FGA) e Pedagogia (diurno). Dessa forma, pode-se entrever que a mudança de curso parece ser um mecanismo utilizado por alunos de cursos específicos da Universidade de Brasília.

Gráfico 3 Distribuição do grau de saídas via transferências internas

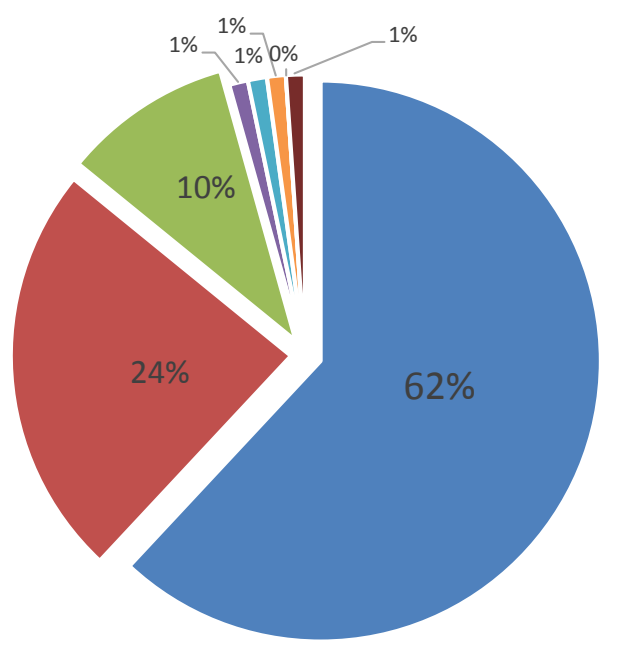

$\begin{array}{ll}\text { - } 0 \text { a } 10 \text { saídas } & \text { (57 cursos) } \\ \text { - } 11 \text { a } 20 \text { saídas } & \text { ( } 22 \text { cursos) } \\ \text { - } 21 \text { a } 30 \text { saídas } & \text { ( } 9 \text { cursos) } \\ \text { - } 31 \text { a } 40 \text { saídas } & \text { ( } 1 \text { curso) } \\ \text { - } 41 \text { a } 50 \text { saídas } & \text { ( } 1 \text { curso) } \\ \text { - } 51 \text { a } 60 \text { saídas } & \text { ( } 1 \text { curso) } \\ \text { - } 61 \text { a } 70 \text { saídas } & \text { (nenhum curso) } \\ \text { - } 70 \text { saídas } & \text { ( } 1 \text { curso) }\end{array}$

lia

Quanto à distribuição do grau de entradas, houve quantidade considerável de cursos concentrados também nos menores intervalos. Ou seja, grande parte dos cursos recepcionou até 20 alunos transferidos. De modo intermediário, 8 cursos receberam de 21 a 40 alunos. Por fim, de todos os cursos de graduação, 5 se destacaram por terem registrado mais de 50 ingressos, sendo que desses cursos, apenas 3 recepcionaram mais de 70 alunos.

Em contraposição ao fluxo de saídas concentrado em específicos cursos de graduação, percebeu-se maior diversidade um pouco maior entre os cursos de graduação de entrada das transferências internas. Mesmo assim, parece haver um movimento homogêneo das transferências internas rumo a alguns cursos específicos, tais como: Psicologia, Comunicação Social e Engenharia Mecânica. 
Gráfico 4 Distribuição do grau de entradas via transferências internas

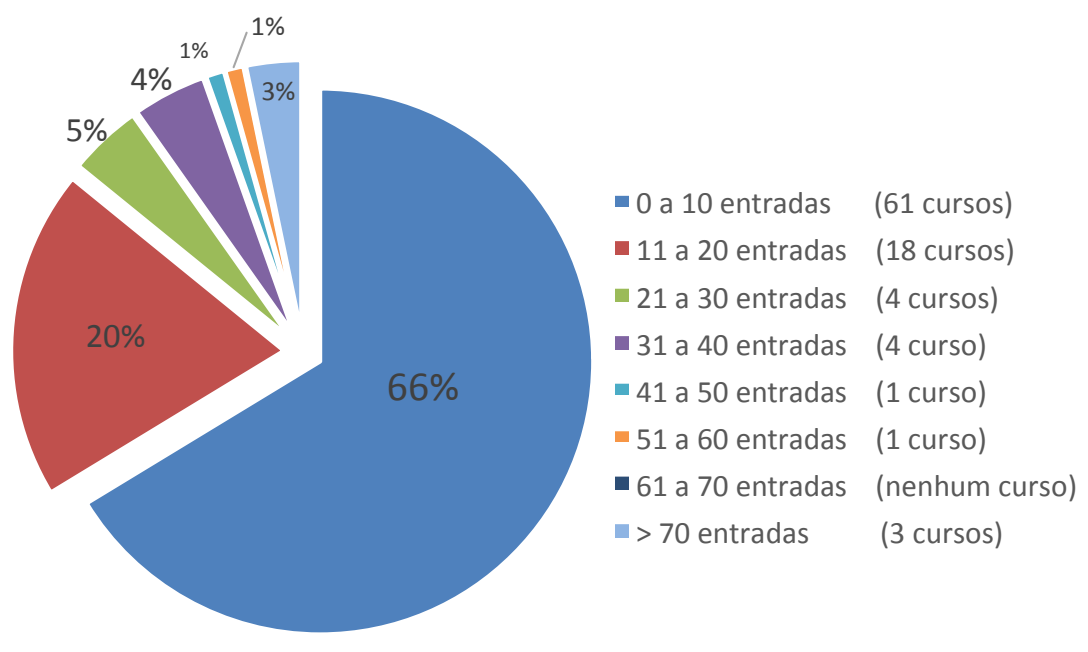

Em suma, percebe-se que as transferências internas não ocorrem de maneira aleatória entre os cursos de graduação. Metaforicamente, pode-se imaginar a rede de transferência interna como um balde cheio de água com pequenos furos preenchendo determinados recipientes. Isto é, o movimento de emigração, saída de alunos, ocorre com maior significância em determinados cursos e o movimento de imigração, entrada de alunos, destina-se a específicos cursos. Essas características evidenciam uma distribuição de grau com cauda pesada, assim como uma rede de citação entre artigos, conforme exemplificado por Figueiredo (2011).

\subsubsection{Densidade}

Conforme salientado no capítulo teórico, a densidade de uma rede refere-se à quantidade de arestas ou ligações entre os vértices que estão, de fato, presentes. Ou seja, trata-se de uma métrica que "contabiliza quantas ligações de fato existem na rede, expressando esse número em termos de ligações potenciais que poderiam existir na rede" (PRELL, 2012, p. 167).

Em termos de densidade, o percentual de ligações formadas entre os cursos de graduação, dentro do total possível para essa rede, foi de $11,5 \%$. Isto é, do potencial de ligações que essa rede poderia ter, 11,5\% foram estabelecidas. Segundo Prell (2012), quanto maior o percentual encontrado, mais densa é a rede. Apesar de não haver valores pontuais que permitam categorizar os valores 
encontrados para a densidade de uma rede, Prell (2012) sugere que uma densidade alta é dada para um percentual de $50 \%$ ou mais.

Assim, o percentual da rede de transferência sugere que ela não é densa, 0 que já era de se esperar considerando-se o tamanho da rede (92 x 92). Conforme Prell (2012), devido ao fato de extensas redes possuírem o potencial para a formação de muitas ligações entre seus vértices, a possibilidade de alta densidade nessas redes é remota. Em contraponto, em redes de pequena extensão é comum altos percentuais de densidade (ALEJANDRO; NORMAN, 2005).

No contexto da rede de transferência interna, a densidade fornece indícios acerca da interação entre os cursos de graduação. Conforme já salientado, na UnB não houve regras nos editais analisados que limitassem as transferências internas entre os cursos de graduação. Ou seja, qualquer combinação $X(i, j)$, em que $i$ seja o curso de origem e $j$ o curso de destino, poderia ser formada.

Apesar disso, a densidade deixa a entrever que a variedade de combinações entre cursos de origem e cursos de destino, entre as transferências internas, é baixa. Dessa forma, essas evidências de que as combinações sejam pontuais corroboram com as análises de distribuição de graus de saída e de ingresso no cursos, realizadas anteriormente. Significa dizer que as transferências internas não ocorrem desordenadamente na rede, mas sim entre determinados cursos de graduação. A centralidade de intermediação, conforme abordado abaixo, pode fornecer indícios de quais são esses cursos de graduação.

\subsubsection{Centralidade de Intermediação}

Entre as métricas de centralidade, o grau de intermediação de uma rede pode auxiliar no entendimento de quais vértices são os mais centrais em determinada rede. Segundo Prell (2012), a literatura tem demonstrado que a centralidade de intermediação é a métrica que melhor identifica os vértices centrais de uma rede, os quais podem ser analisados, em alguns tipos de rede, em termos de liderança e potencial de influência.

O grau de intermediação de uma rede considera a rede como um todo no cômputo da centralidade de intermediação de cada vértice, conforme salientado no capítulo teórico. Em termos práticos, essa métrica evidencia qual(is) vértice(s) que, 
uma vez retirado(s), desestrutura $(m)$ toda a rede. Nesse sentido, o grau de intermediação foi utilizado no contexto desse estudo para se evidenciar quais são os cursos de graduação que mais protagonizaram as transferências internas na UnB, no período analisado.

Esse protagonismo não é dado em função da quantidade de saídas ou de ingressos registrada pelos cursos de graduação, mas sim em função das ligações estabelecidas estrategicamente. São cursos de graduação que, se retirados da rede, provavelmente causaria impacto nos rumos das transferências internas. A tabela 4 elenca os cursos de graduação mais centrais, em termos de intermediação, na rede de transferência interna, conforme o grau de centralidade de intermediação normalizado.

Conforme salientado, as ofertas para a mudança de curso variam de semestre para semestre a depender da existência de vagas ociosas entre os cursos de graduação. Naturalmente pode até mesmo não haver oferta por esse motivo. Percebeu-se que alguns cursos, a exemplo de Administração (noturno), Ciências Econômicas, Odontologia e Ciências Biológicas, ao ofertarem vagas para as transferências internas, atraem inscrições de candidatos que, se não fosse pelas vagas nesses cursos, estariam menos propensos a participarem do processo de seleção de transferência interna.

Tabela 4 Grau de centralidade de intermediação

\begin{tabular}{|c|c|}
\hline Cursos de graduação & $\begin{array}{l}\text { Grau de centralidade de } \\
\text { intermediação normalizado }\end{array}$ \\
\hline Comunicação Social & 12.550 \\
\hline Psicologia & 7.059 \\
\hline Ciências Sociais & 6.808 \\
\hline Administração (noturno) & 6.128 \\
\hline Ciências Econômicas & 5.938 \\
\hline Odontologia & 4.733 \\
\hline Engenharia Mecânica & 4.334 \\
\hline Ciências Biológicas (diurno) & 3.561 \\
\hline Letras (diurno) & 3.515 \\
\hline Engenharia de Produção & 3.204 \\
\hline Pedagogia (diurno) & 3.165 \\
\hline Fisioterapia & 3.043 \\
\hline
\end{tabular}


O curso de Engenharia (FGA), ciclo básico do campus Gama, por exemplo, não consta entre aqueles mais centrais em termos de intermediação, apesar de esse curso figurar entre aqueles com maior saída de alunos em se tratando de transferências internas. Por outro lado, o curso de Fisioterapia apesar da quantidade de saída e de ingresso inexpressiva quando comparado aos demais da rede de transferência interna, figurou entre os mais relevantes em termos de centralidade de intermediação e o mais significativo do campus Ceilândia (FCE/UnB). Tem-se, assim, que a centralidade de intermediação sublinha a posição do vértice na rede e não a quantidade de interações dele para com os demais (ALEJANDRO; NORMAN, 2005; PRELL, 2012).

Entre as análises aos vértices que desempenham função intermediadora é a queda na quantidade de inscrições com a retirada deles da rede de transferência interna. Por exemplo, se um determinado curso é utilizado como meio de acesso à Universidade de Brasília para posterior transferência interna a outro curso e, uma vez que esse curso é, hipoteticamente, retirado dos editais de transferência interna, presume-se então que a rede possuirá uma nova configuração.

De mesmo modo, a retirada de cursos cobiçados dos editais de transferência interna pode desestimular a participação de estudantes nessa modalidade. Como exemplo, no estudo de Souza e Toassi (2015), alunos que mudaram de turno num mesmo curso, revelaram que, entre os motivos que os levaram a isso, estava a oportunidade de fazê-lo por meio de transferência interna. Nesse contexto, vislumbram-se os possíveis dilemas que possivelmente 0 aluno enfrentaria: permanecer em curso que não o pretendido, evadir da instituição para uma privada e/ou evadir do sistema de ensino superior como um todo.

\subsubsection{Fluxo entre os turnos via transferência interna de alunos}

O ensino superior brasileiro é ofertado, historicamente, no turno diurno ou integral (VARGAS; PAULA, 2013). Em nome da democratização do acesso às universidades, a Reestruturação e Expansão das Universidades Federais - REUNI passou a aumentar as vagas no turno noturno (VARGAS, PAULA, 2013). Corroborando com o cenário das demais instituições federais de ensino superior, os 
cursos de graduação ofertados pela Universidade de Brasília são majoritariamente diurnos (BRASIL, 2015).

Os estudantes de cursos noturnos são, geralmente, associados à figura do estudante-trabalhador ou trabalhador-estudante (TERRIBILI FILHO; NERY, 2009). Essa característica advém, sobremodo, de que "a condição de trabalho impõe limites ao turno em que o aluno pode estudar" (VARGAS; PAULA, 2013, p. 471). De forma, é natural, portanto, a rotina de conciliação entre estudos e trabalhos ou, em não raras vezes, a tentativa de conciliação. Os vultosos afazeres entre estudantes que trabalham é realçado pela literatura como potencial causa à evasão (Di PIETRO, 2007; OQUENDO, 2008).

Sob o prisma da existência de pontes de acesso entre graduações (CUNHA; TUNES; SILVA, 2001), a migração entre cursos pode estar direcionada rumo àqueles mais prestigiados socialmente, entre os quais não estão inseridos os cursos noturnos nas áreas de humanas e sociais (VARGAS; PAULA, 2013). Havia expectativa de uma tendência de saída do turno noturno para o diurno, considerando-se que os cursos noturnos na Universidade de Brasília possuem características recorrentemente ligadas aos fatores que levam à evasão: são menos concorridos nos exames de admissão, correspondem em grande maioria a licenciaturas e possuem duração maior (LIMA; MACHADO, 2014; SOUZA; TOASSI, 2014).

Souza e Toassi (2014) constataram que entre os motivos que levaram estudantes a trocarem o turno noturno pelo diurno, embora sem trocar de curso, estavam: o tempo de duração do curso diurno ser menor, a disponibilidade do mesmo curso no turno diurno e a possibilidade de mudar para esse curso sem sair da instituição por transferência interna. A qualidade não foi um fator explicativo encontrado no estudo desses autores para a troca de turno entre os universitários abordados por eles.

Por outro lado, também era esperado, entre vários fatores, que no decorrer da graduação, o estudante, diante da necessidade de trabalho remunerado, fosse de alguma forma influenciado no processo de transferência interna a optar por um curso noturno visando à continuidade de seus estudos. É justamente na idade em que a maioria dos estudantes se encontram no ensino superior que a importância do trabalho aumenta (VARGAS; PAULA, 2013). Não obstante, a oferta de trabalho se 
situa majoritariamente no horário comercial, o que implica ao aluno somente a opção pelo turno da noite (VARGAS; PAULA, 2013).

Em números absolutos, conforme a tabela 5, registrou-se um movimento maior de saída do diurno para o noturno (152 casos) do que do noturno para o diurno (143 casos). Em termos proporcionais, sobressaem as migrações do noturno direcionadas ao diurno. Entre as transferências internas que não implicaram em mudança de turno, 701 casos foram registrados no turno diurno contra 54 casos no noturno.

Tabela 5 Migração entre turnos via transferência interna na UnB

\begin{tabular}{|c|c|c|c|}
\hline & \multicolumn{2}{|c|}{ Turno de Destino } \\
\hline & & Diurno & Noturno \\
\hline \multirow{2}{*}{ 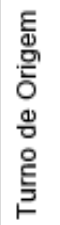 } & 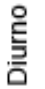 & 701 & 152 \\
\hline & 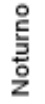 & 143 & 54 \\
\hline
\end{tabular}

Fonte: Elaboração própria a partir de dados da Universidade de Brasília

Os dados, esquematizados em rede na figura 4, revelaram que não há indícios de utilização do mecanismo de transferência interna para a migração de um turno para o outro. A maior participação nas transferências internas provém de cursos diurnos. Possivelmente o fato de a maioria dos cursos da Universidade de Brasília, incluindo seus campi, serem ofertados nesse período explique a maior recorrência de transferências internas nesse turno. Trata-se de uma característica do ensino superior brasileiro, o qual está mais estruturado aos cursos ofertados em período diurno ou integral do que para os noturnos (VARGAS; PAULA, 2013).

É válido salientar que a Universidade de Brasília possui editais específicos para a mudança de turno, dentro de um mesmo curso. Esses dados relativos ao processo tão-somente de mudança de turno não foram considerados nesse estudo.

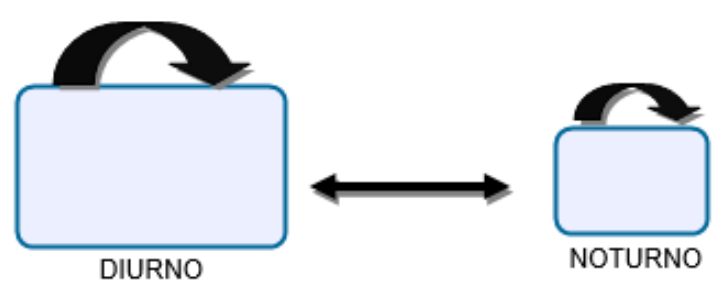

Figura 4 Rede transferência interna entre os turnos da UnB 
Fonte: Elaboração própria a partir de dados da Universidade de Brasília.

\subsubsection{Fluxo entre os campi via transferência interna de alunos}

A Universidade de Brasília é considerada multicampi desde 2006 e está descentralizada pelos campi: Darcy Ribeiro (Plano Piloto), UnB Ceilândia (FCE/UnB), UnB Gama (FGA/UnB) e UnB Planaltina (FUP/UnB). O campus Darcy Ribeiro é o mais antigo da UnB, inaugurado em 1962. Os demais foram inaugurados entre meados de 2006 a 2008. Em termos de distância geográfica, a maior distância é entre os campi da UnB Gama (FGA) e da UnB Planaltina (FUP): 72,1 km. A menor distância registrada é entre os campi UnB Ceilândia (FCE) e UnB Gama (FGA): 32,1 $\mathrm{km}$.

Atualmente, grande parte dos cursos de graduação das mais diversas áreas do conhecimento é ofertada no campus Darcy Ribeiro. A UnB Ceilândia (FCE), especializada em cursos de saúde, oferta os cursos de graduação de Enfermagem, Farmácia, Fisioterapia, Fonoaudiologia, Saúde Coletiva e Terapia Ocupacional. A UnB Gama (FGA) é um campus voltado ao ensino e formação de profissionais em áreas da engenharia, tais como: Aeroespacial, Automotiva, Eletrônica, Energia e Software. Conforme salientado nesse estudo, somente depois de cursada a formação básica em engenharia é que o estudante seleciona a área de especialização. Os cursos ofertados pela UnB Planaltina (FUP) são direcionados às áreas de ciências naturais e agrárias, sendo eles: Ciências Naturais, Educação do Campo, Gestão do Agronegócio, Ciências Naturais e Gestão Ambiental.

De modo geral, nem todos os cursos ofertados no campus Darcy Ribeiro também o são nos demais campi e vice-versa. Dessa forma, a depender do curso, a transferência interna pode implicar em mudança de campus no âmbito da UnB. Destarte, buscou-se verificar o encadeamento provocado pelas transferências internas nos fluxos de alunos entre os campi da Universidade de Brasília. Na tabela 7 estão listados os quantitativos de alunos que deixaram determinado campus rumo a outro como consequência da transferência interna. Na diagonal destacada estão os quantitativos de transferências internas adstritas ao mesmo campus. 
Tabela 6 Migração entre os campi via transferência interna na UnB

\begin{tabular}{|c|c|c|c|c|c|}
\hline & \multicolumn{4}{|c|}{ CAMPUS DE DESTINO } \\
\hline & & $\begin{array}{l}\text { Darcy } \\
\text { Ribeiro }\end{array}$ & FCE & FGA & FUP \\
\hline \multirow{4}{*}{ 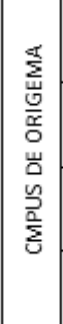 } & 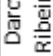 & 847 & 4 & 3 & 1 \\
\hline & 岀 & 16 & 21 & 1 & 0 \\
\hline & 告 & 118 & 0 & 20 & 0 \\
\hline & $\frac{5}{4}$ & 18 & 0 & 0 & 1 \\
\hline
\end{tabular}

Fonte: Elaboração própria a partir de dados da Universidade de Brasília.

De acordo com a tabela 7 , há uma tendência de migração dos alunos rumo ao campus Darcy Ribeiro, com origem principalmente na UnB Gama e na UnB Planaltina. Em se tratando da UnB Ceilândia, todavia, a quantidade de alunos que realizam a transferência interna sem, contudo, abandonar o campus é maior do que a quantidade que abandona. Ou seja, apesar de mudarem de curso, os alunos tendem a permanecer na FCE/UnB. Representando os valores da tabela 7 numa rede de migração de campus via transferência interna, obteve-se a rede da figura 5 .

Nessa rede, os vértices representam os campi da Universidade de Brasília. $O$ tamanho de cada vértice embasou-se nos fluxos internos aos campus, isto é, quando o campus de origem e o campus de destino se coincidem. As arestas bidirecionadas indicam os fluxos externos aos campus, sendo que a espessura representa a amplitude desses fluxos.

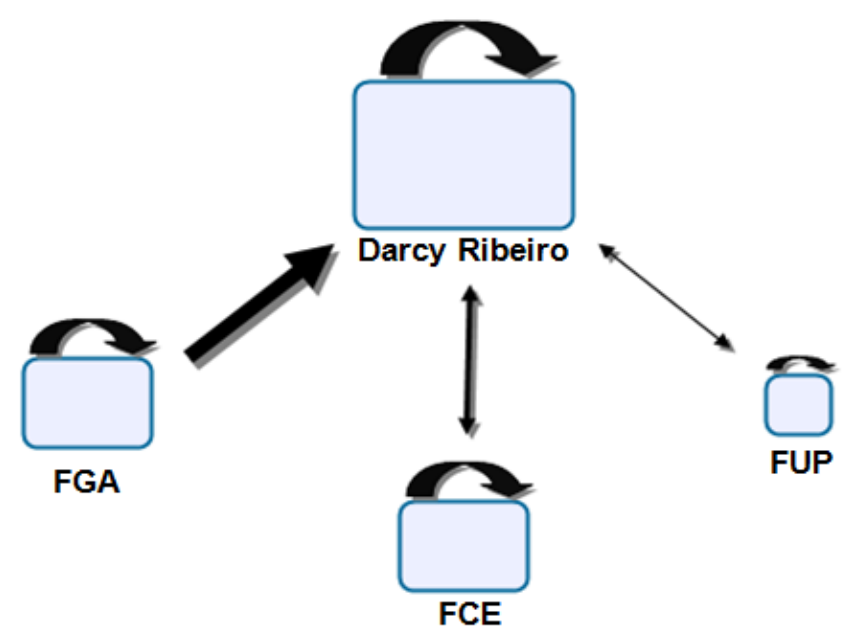

Figura 5 Rede transferência interna entre os campi da UnB

Fonte: Elaboração própria a partir de dados da Universidade de Brasília. 
De acordo com a figura 5, o maior fluxo parece ser da FGA em direção ao campus Darcy Ribeiro. Com auxílio de tabelas dinâmicas do programa Microsoft Excel foi possível traçar os cursos de destino dos alunos transferidos da UnB Gama e notar que, majoritariamente, eles migraram para engenharias. Considerando o total de 138 alunos, os cursos de destino mais expressivos foram: Engenharia Mecânica (28\%), Engenharia Elétrica (18\%) e Engenharia de Produção (17\%).

Essas constatações, mais uma vez, evidenciam que a saída de estudantes de cursos de engenharia não ocorre por dificuldades de se acompanhar o curso, tendo em vista que alunos de engenharias tendem a trocar de áreas, dentro das próprias engenharias. Quanto aos cursos de destino do total de 38 alunos provenientes da FCE, os mais expressivos foram cursos da própria FCE: Enfermagem - Ceilândia (24\%) e Farmácia - Ceilândia (16\%). Dentre aqueles que não são ofertados nesse campus, o mais recorrente como curso de destino foi Odontologia (13\%). Entre os 19 oriundos da FUP, os destinos mais frequentes foram Geologia (16\%), Engenharia Mecânica (11\%) e Engenharia Química (11\%).

Por fim, em relação aos 855 alunos provenientes do campus Darcy Ribeiro, apenas 8 não permaneceram nele. O fluxo de transferência interna nos limítrofes do campus Darcy Ribeiro pode ser atribuído ao fato de que a maioria considerável de cursos de graduação é ofertada nesse campus. Nesse campus, os cursos de destino mais escolhidos foram Psicologia (10\%), Comunicação Social (9\%) e Administração (5\%). O anexo B contém tabelas informando todos os demais cursos de destino de todos os campi.

\subsection{As transferências internas de alunos entre as áreas de conhecimento}

Os editais de transferência interna da UnB não restringem a mudança de curso dentro da mesma área de conhecimento. Por exemplo, um estudante da área de Ciências Humanas, Letras e Artes pode optar pela transferência interna para qualquer curso, quer seja dessa mesma área de conhecimento, quer seja de outra, desde que tenha cumprido os requisitos básicos dispostos em edital. Assim, é de se pressupor que as interações estabelecidas dentro da rede de transferências internas entre cursos de graduação configuram-se de maneira emaranhada, já que os fluxos podem ser estabelecidos entre quaisquer cursos. 
As evidências da literatura sobre redes, entretanto, sugerem que embora possa haver conectividade, direta ou indireta, entre os elementos dispersos, os atores mais similares tendem a estabelecer mais conexões entre si do que com outros não similares (EVERTON, 2012; KADUSHIN, 2012; PRELL, 2012). No contexto das transferências internas entre graduações, corresponde a afirmar que os cursos congêneres interligam-se mais do que aqueles desconexos. Isto é, presumese que as interações entre cursos de graduação pertencentes a mesma área de conhecimento sejam mais densas. Entretanto, as interações ocorridas entre diferentes áreas de conhecimento não podem ser desconsideradas.

É importante mencionar que a decisão de mudar de curso não ocorre, necessariamente, por motivos de falhas e reprovações entre os estudantes. Em geral, a escolha do curso de graduação ocorre em idade ainda precoce (BRASIL, 1997; REIS; CUNHA; SPRITZER, 2012), sendo natural que no decorrer da graduação os estudantes optem (BARDAGI, HUTZ; 2009) ou possam ser orientados a mudar de carreira (ORTIZ, DEHON; 2013).

Essa mudança de curso visando à melhor combinação entre as aptidões do indivíduo e das competências requeridas pelo curso ou carreira, contudo, não parece ser uma questão simples, considerando que, no momento da reopção de curso, os estudantes geralmente ainda não escolheram um novo curso (BARDAGl; HUTZ, 2009) ou ainda estão incertos sobre a nova escolha (MAGALHÃES; REDIVO, 1998). Diante dessas situações, Sbardelini (2001), Bardagi e Hutz (2009) sugerem a presença de suporte institucional, o qual é defendido por Rodrigues (2006) como um dever das IES na busca pela permanência de seus alunos.

Não obstante, diante das evidências que sinalizam para a tendência de formação de subgrupos dentro de redes, conforme a perspectiva da literatura acerca análises de redes sociais, e considerando as evidências da literatura sobre evasão de que alunos que abandonam determinado curso e retornam ao ensino superior o faz no mesmo curso ou em curso análogo (FREIRE, 2015; SOUZA; TOASSI, 2015), buscou-se averiguar, dentro do contexto da rede de transferências internas, quão ajustadas as mudanças de cursos ocorrem dentro das áreas de i) Ciências Agrárias, Exatas e Engenharias; ii) Ciências Humanas, Letras e Artes e iii) Ciências Biológicas e da Saúde. Para tanto, procedeu-se à análise faccional com 3 sub-redes. Para melhor visualização das interações entre as sub-redes, coloriu-se cada uma por uma cor: vermelha, verde e roxa, conforme figura 6. 


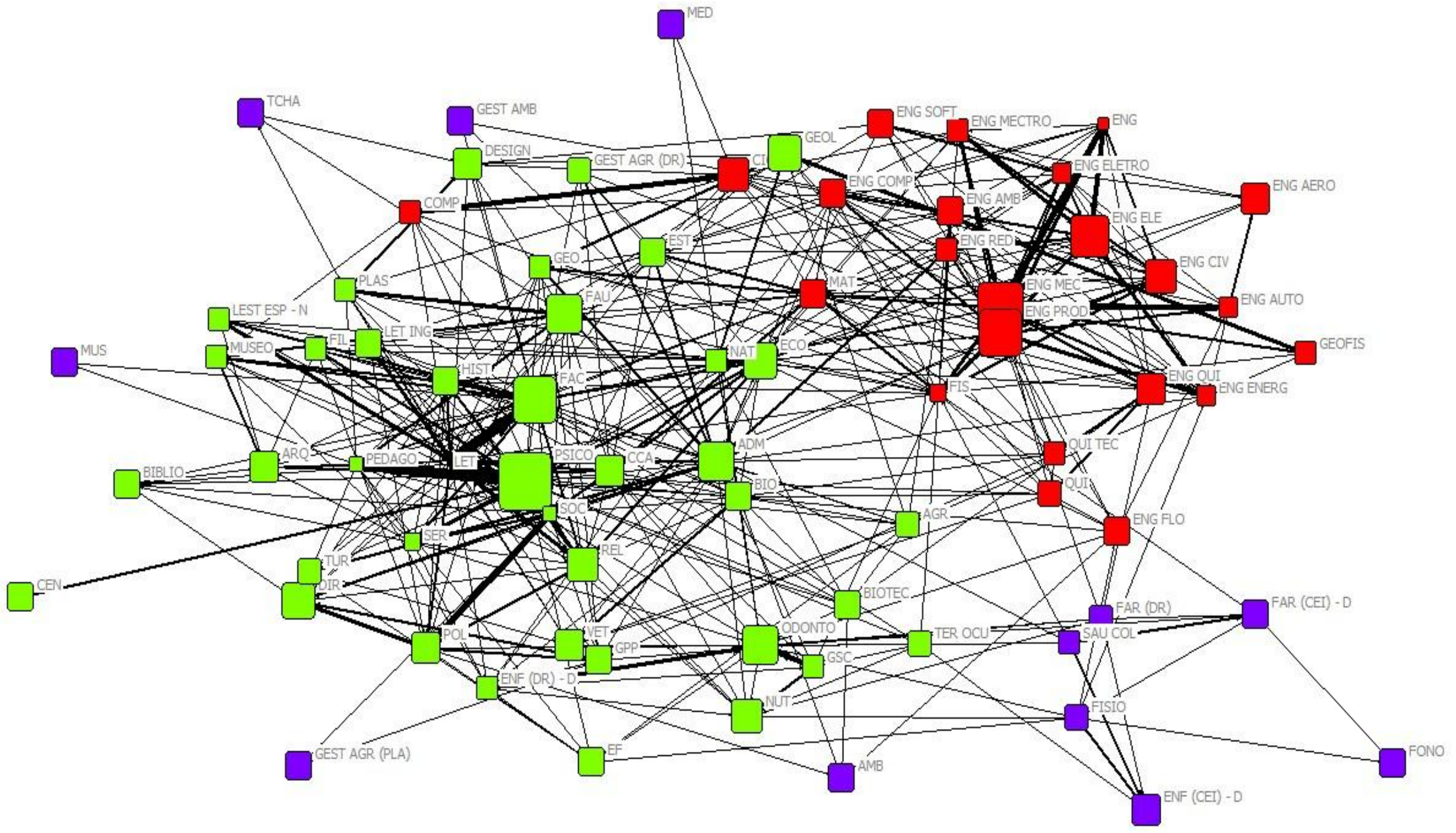

Figura 5 Rede de transferência interna entre os cursos da UnB

Fonte: Elaboração própria a partir de dados da Universidade de Brasília. 
O quadro 6 lista os cursos que supostamente pertenceriam a cada uma das três facções obtidas, conforme sugerido pelo algoritmo. A não correspondência entre a classificação dada pelo algoritmo e a classificação adotada no estudo dos cursos para com suas áreas de conhecimento é destacada em negrito.

\begin{tabular}{|c|c|}
\hline $\begin{array}{l}\text { Áreas de } \\
\text { Conhecimento } \\
\text { adaptadas }\end{array}$ & $\begin{array}{c}\text { Classificação dos Cursos de graduação dada pelas facções sugeridas } \\
\text { pelo algoritmo do Netdraw }\end{array}$ \\
\hline $\begin{array}{l}\text { Ciências Agrárias, } \\
\text { Exatas e Engenharias }\end{array}$ & $\begin{array}{l}\text { Ciência da Computação, Computação, Engenharia, Engenharia Aeroespacial, } \\
\text { Engenharia Ambiental, Engenharia Automotiva, Engenharia Civil, Engenharia da } \\
\text { Computação, Engenharia de Energia, Engenharia de Produção, Engenharia de } \\
\text { Redes de Comunicação, Engenharia de Software, Engenharia Elétrica, Engenharia } \\
\text { Eletrônica, Engenharia Florestal, Engenharia Mecânica, Engenharia Mecatrônica, } \\
\text { Engenharia Química, Física, Geofísica, Matemática, Química, Química Tecnológica }\end{array}$ \\
\hline $\begin{array}{l}\text { Ciências Humanas, } \\
\text { Letras e Artes }\end{array}$ & $\begin{array}{l}\text { Administração, Agronomia, Arquitetura e Urbanismo, Arquivologia, Artes Cênicas, } \\
\text { Artes Plásticas, Biblioteconomia, Biotecnologia, Ciência Política, Ciências } \\
\text { Biológicas, Ciências Contábeis, Ciências Econômicas, Ciências Naturais, } \\
\text { Ciências Sociais, Comunicação Social, Design, Direito, Educação Física, } \\
\text { Enfermagem (Darcy), Estatística, Filosofia, Geografia, Geologia, Gestão De } \\
\text { Políticas Públicas, Gestão De Saúde Coletiva, Gestão do Agronegócio (Darcy), } \\
\text { História, Letras Espanhol, Letras Inglês, Medicina Veterinária, Museologia, } \\
\text { Nutrição, Odontologia, Pedagogia, Psicologia, Relações Internacionais, Serviço } \\
\text { Social, Terapia Ocupacional, Turismo. }\end{array}$ \\
\hline $\begin{array}{l}\text { Ciências Biológicas e } \\
\text { da Saúde }\end{array}$ & $\begin{array}{l}\text { Enfermagem (FCE), Farmácia (Darcy Ribeiro), Farmácia (FCE), Fisioterapia, } \\
\text { Fonoaudiologia, Gestão Ambiental, Gestão do Agronegócio (FUP), Medicina, } \\
\text { Música, Saúde Coletiva, Teoria Crítica e História da Arte. }\end{array}$ \\
\hline
\end{tabular}

Quadro 6 Classificação dos cursos sugerida pelo algoritmo utilizado

Com algumas exceções, a tentativa de se organizar os cursos de graduação entre as três grandes áreas de conhecimento funcionou satisfatoriamente, a exceção da área de Ciências Biológicas e da Saúde para a rede como um todo, apesar de recorrência dos cursos de saúde da UnB Ceilândia nessa facção, conforme ilustrado na rede de transferência interna representada na figura 6.

Quanto às interações na grande área de Ciências Agrárias, Exatas e Engenharias, representada majoritariamente pelos vértices de cor vermelha, notase, sobremaneira, uma intensa relação entre os cursos de Exatas e as Engenharias. Em relação às Engenharias, a expressividade entre elas é tão forte que há de se considerar a pertinência de um ciclo básico orientado para a escolha das carreiras de engenharia, uma vez que os dados sugerem que parte desses alunos tem certeza que querem ser engenheiros, mas não sabem ao certo qual engenharia escolher. São estudantes que, assim como aqueles do estudo de Souza e Toassi (2015), estão seguros quanto à escolha profissional, tendo apenas realizado uma readaptação na trajetória na universidade.

A transferência interna de uma engenharia para outra pode estar relacionada à falta de identificação com a área da engenharia escolhida, assim como ao fato da 
engenharia em que o aluno foi aprovado não corresponder à primeira opção de curso ou até mesmo com o desconhecimento da realidade e natureza da área escolhida, conforme fatores listados por Meyer e Marx (2014), Santos, Lage Junior e Ribeiro (2015).

Em complemento com essa análise, pode-se também especular a possibilidade de um aluno optar por determinado curso de destino na transferência interna motivado pelo posterior aproveitamento das disciplinas já cursadas no curso de origem. Ou seja, o aluno ao optar pela transferência interna, analisa preliminarmente o currículo dos prováveis cursos de destino e, no intuito de maximizar o aproveitamento das disciplinas do curso de origem, tende a escolher um curso da mesma área de conhecimento.

Essas possibilidades vão ao encontro do comportamento de indivíduos que possuem consciência de quem pertencem a determinado grupo, e, por isso, interagem mais com outros indivíduos que são membros desse grupo do que com não-membros (KADUSHIN; 2012). Em relação aos cursos pertencentes à área de conhecimento de Exatas, nenhum curso foi classificado pelo algoritmo nas demais áreas de conhecimento. As exceções ficaram à cargo dos cursos de Ciências Agrárias, em que houve registro de alguns deles nas demais áreas.

No que seria o equivalente à classificação de Ciências Humanas, Letras e Artes, representada em sua maioria pelos vértices de cor verde, a intensidade das interações nessa área de conhecimento parece ser ainda mais expressiva, conforme se evidencia pela quantidade e espessura das ligações entre os cursos. Quanto ao tamanho dos vértices, conforme salientado, eles são dados em consonância com os valores de resultados líquidos obtidos. Por esse motivo, os cursos de Psicologia e Comunicação Social, dentro dessa área de conhecimento, se destacam pelo maior tamanho de seus vértices.

Por meio do recurso de tabelas dinâmicas do Microsoft Excel, analisou-se as interações dos cursos em negrito classificados na área de Ciências Humanas, Letras e Artes no intuito de se descobrir o possível motivo da classificação dada a eles pelo algoritmo. Percebeu-se que esses cursos estabeleceram conexões com outros de considerável intermediação na rede, em especial aqueles da área de Ciências Humanas, Letras e Artes. Assim, por estabelecerem ligações com tais cursos, o algoritmo entendeu que eles pertenciam a uma mesma área. Sendo assim, interpreta-se que os cursos destacados em negrito exerceram papel de conectores 
entre suas áreas de conhecimento com a área de Ciências Humanas, Letras e Artes.

Por seu turno, na classificação de Ciências Biológicas e da Saúde, não houve muito sucesso no ajuste entre a facção identificada pelo algoritmo e os cursos que compõem essa área. Percebe-se a concentração de cursos ofertados pelo campus UnB Ceilândia (FCE/UnB) nessa facção, os quais são da área de Saúde. De modo geral, Newman (2003) afirma que é comumente observado nas redes de relacionamentos sociais a maior frequência de interações entre vértices semelhantes. Todavia, conforme salientado por Kadushin (2012), qualquer unidade social tende a ser organizada em grupos, embora nem todas as conexões estabelecidas pelos componentes desse grupo fiquem adstritas às fronteiras a ele.

Dessa maneira, lança-se a pergunta: faz sentido a criação de mecanismos de bonificação na média ponderada utilizada no processo de transferência interna para mudanças de curso dentro de uma mesma área de conhecimento? O estímulo à mudança de curso dentro de uma mesma área de conhecimento colaboraria para o maior aproveitamento de disciplinas do curso de origem, o que maximizaria os recursos públicos investidos até então.

Em consonância com as evidências constatadas nesse estudo, percebeu-se que as transferências internas ocorrem não com mudanças bruscas, mas dentro de um ajuste fino. Sendo assim, acredita-se que a criação de bonificação a fim de incentivar as mudanças de cursos internamente entre as grandes áreas de conhecimento apenas reforçaria o que já naturalmente acontece na prática.

Ademais, vislumbra-se a ideia de um ciclo básico ou implementação de cursos generalistas nos períodos iniciais do ensino superior para as grandes áreas de conhecimento como estratégia para melhor orientar o aluno sobre a carreira a ser escolhida, conforme recomendado por McMillan (2005). Como exemplo, citam-se as transferências internas da área de Ciências Agrárias, Exatas e Engenharias em que os cursos foram classificados satisfatoriamente pelo algoritmo. Nesses moldes, 0 ciclo básico teria como objetivo a orientação para a escolha de carreiras.

Há evidências de que mudança de curso não ocorre, necessariamente, por motivos de falhas e reprovações entre os estudantes. No momento de ingresso no ensino superior, a escolha do curso de graduação costuma ocorrer em idade precoce (BRASIL, 1997; REIS; CUNHA; SPRITZER, 2012), sendo recomendado que no decorrer da graduação os estudantes optem ou possam ser orientados sobre as possíveis carreiras (BARDAGI, HUTZ; 2009; ORTIZ, DEHON; 2013). Essas 
constatações corroboram com a ideia de um ciclo básico como facilitador da escolha do curso de ensino superior.

\subsection{As transferências internas de alunos e o efeito trampolim}

A escolha pelo curso de graduação é influenciada, sobremaneira, por fatores de ordem pessoal e social, tais como: o prestígio social da profissão, as possibilidades de desenvolvimento na carreira, pressões familiares, habilidades e aptidões pessoais, condições sociais, entre outros (BRASIL, 1997; ZAGO, 2006). Além do mais, a escolha pelo curso superior acontece, em média, em idade ainda precoce. É uma decisão que influencia os rumos da vida do estudante de modo quase definitivo (BRASIL, 1997; HOTZA; LUCCHIARI, 1998).

Após o ingresso no ensino superior a decisão tomada sobre o curso escolhido pode tomar outros rumos, sobremodo quando incompatibilidades e desencantos surgem entre o que se esperava e o que se vivencia. A frustração pode ser agravada quando o ingresso ocorre em cursos escolhidos em segunda ou terceira opção, conforme apontado pelo Relatório da Comissão Especial de Estudos sobre Evasão nas Universidades Públicas Brasileiras (BRASIL, 1997).

Conforme discutido, o ingresso no ensino superior quando não ocorre no curso realmente pretendido pode ser atribuído ao desejo do estudante de puramente estar na universidade ou até mesmo como trampolim ao curso efetivamente desejado (BRASIL, 1997). É válido salientar também que, conforme sublinha Zago (2006, p. 232), "a origem social exerce forte influência no acesso às carreiras mais prestigiosas, pois a ela estão associados os antecedentes escolares e outros "tickets de entrada". Dessa forma, o ingresso em curso não correspondente à primeira opção pode estar relacionado, de alguma forma, às condições sociais do estudante (ZAGO, 2006). Nas palavras desse autor, "a correspondência entre a condição social e a escolha pela carreira é tendencial e não absoluta" (ZAGO, 2006, p. 232).

Em relação ao efeito trampolim, ele pode ser entendido como o ingresso na universidade de modo estratégico visando a posterior mudança de curso, seja via novo concurso vestibular, seja via transferência interna (BRASIL, 1997; PORTILHO; PEDROZA, 2008; CUNHA; TUNES; SILVA, 2001). No intuito de melhor se preparar para o vestibular, o aluno ingressa na universidade e cursa disciplinas que constem 
no conteúdo programático a ser cobrado nos exames de seleção. Como exemplo, em estudo na Universidade de Brasília, Portilho e Pedroza (2008) registraram ocorrências de ingresso no curso de física como meio de preparo para concorrer ao vestibular das engenharias.

Por outro lado, o ingresso na universidade em determinado curso pode ser uma estratégia para se concorrer, posteriormente, às vagas de transferência interna do curso realmente pretendido (BRASIL, 1997). Assim, o ingresso ocorre, de maneira geral, em cursos de concorrência menos acirrada ou com menor pontuação de ingresso. Nesse sentido, McMillan (2005) constatou que entre as mudanças de cursos havia uma frequência expressiva de estudantes que, à época dos exames de admissão à universidade, não alcançaram elevadas pontuações.

O sentido de efeito trampolim investigado no estudo refere-se à situação em que o aluno utiliza o mecanismo da transferência interna como meio de migração de um curso menos concorrido para um curso mais concorrido. Não significa generalizar que todas as mudanças de curso sejam motivadas por um comportamento estratégico adotado pelo estudante. Conforme foi discutido no referencial teórico, a literatura aponta vários fatores que influenciam a troca de curso de graduação. Nessa seção, buscou-se investigar, em específico, se na rede de transferência interna há propensão à migração de cursos menos concorridos para cursos mais concorridos.

Primeiramente, procedeu-se ao teste de análise cluster a fim de se identificar pares ou conjuntos de cursos de graduação similares entre si na rede de transferência interna. Para tanto, o teste utilizado foi a análise hierárquica de cluster de Johnson (JOHNSON'S HIERARCHICAL CLUSTERING). Conforme salientado no capítulo metodológico, nesse teste a cada nível ou rodada, forma-se um novo subgrupo por meio do agrupamento de dois cursos individuais ou adição de um curso a um subgrupo já existente ou, por fim, pelo agrupamento de dois subgrupos existentes. O procedimento continua até que finalmente todos os cursos de graduação estejam agrupados. Essa similaridade é dada com base na quantidade de interações estabelecidas pelos vértices da rede. Dessa forma, pode-se dizer que a análise hierárquica de Johnson identifica subgrupos, os quais são similares internamente e dissimilares para com o restante da rede.

Os pares ou conjuntos de cursos de graduação similares identificados foram relacionados no gráfico 5 abaixo. 
Gráfico 5 Pares ou conjuntos de cursos similares na rede de transferência interna

HIERASCHICAL CLUSTERTUG

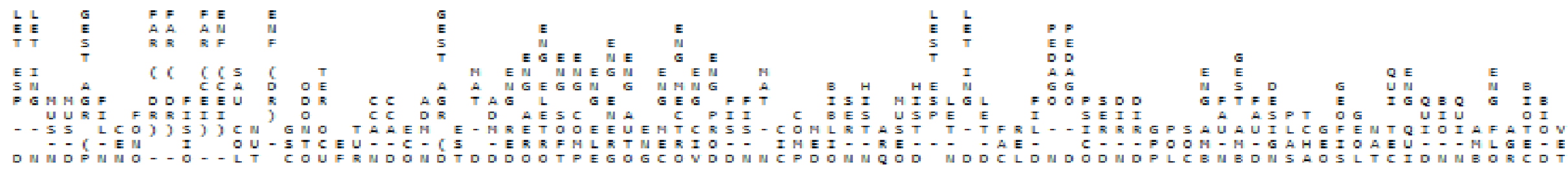

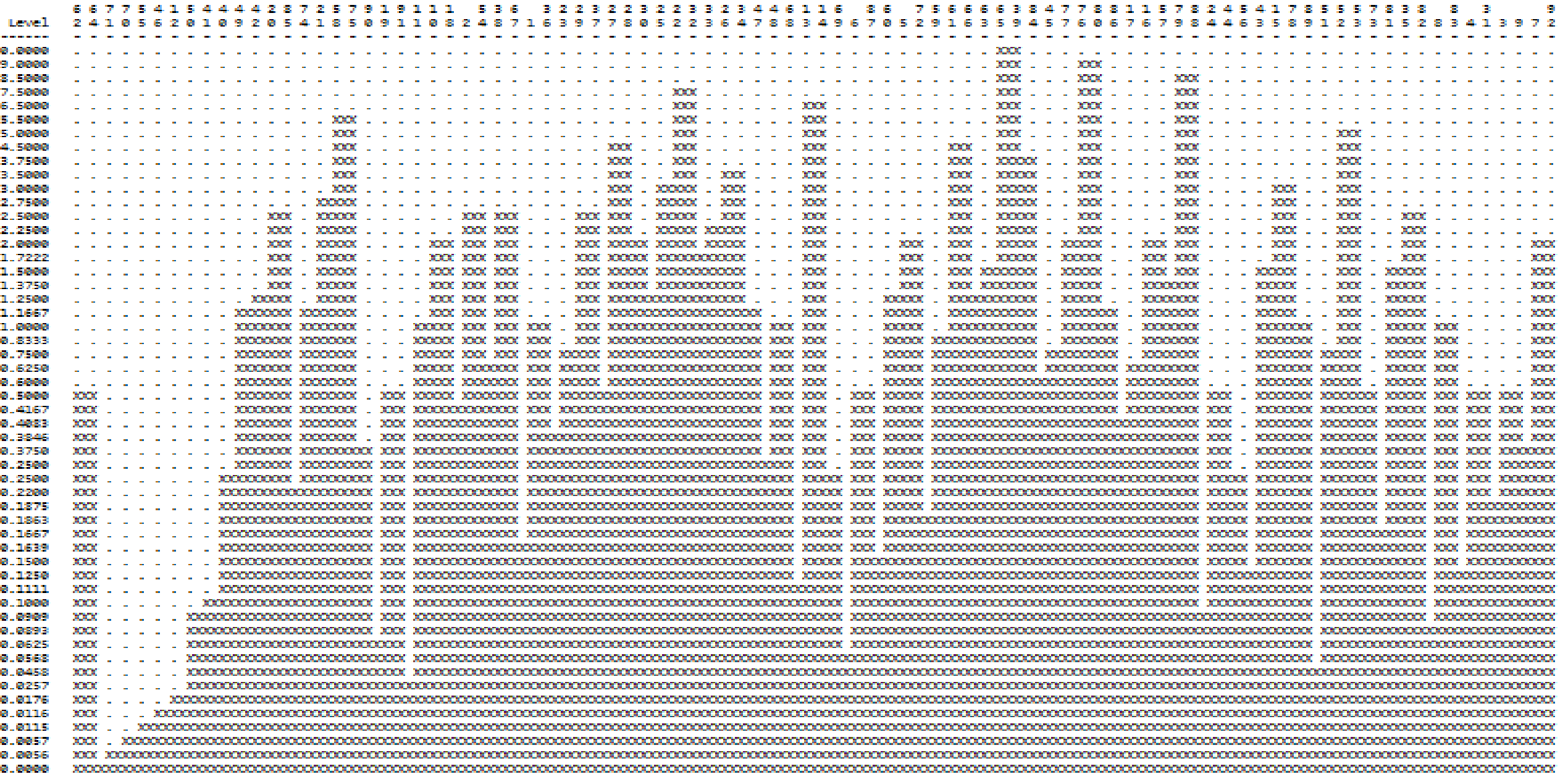

Fonte: Dados da Universidade de Brasília. 
Esse gráfico revela que quanto mais os pares ou conjunto de cursos de graduação apresentaram semelhança entre si, maior o valor (level) atribuído a eles. De modo contrário, quanto menos semelhanças, menor o valor (level). Até o nível 2.000, foram detectados 25 pares ou conjuntos de cursos de graduação. Entre eles, por exemplo, cita-se o par constituído pelos cursos Comunicação Social (FAC) e Letras - diurno (LET-D) ao nível de 10.0000, o qual foi o mais significativo. Uma vez identificados quais os cursos que mais estavam relacionados entre si, investigou-se como se estabeleciam as migrações entre eles. Em especial, investigou-se a possível propensão de migração de cursos menos concorridos para cursos mais concorridos.

Segundo a literatura, a concorrência de um curso de alguma maneira é reflexo, além dos demais fatores já citados, do mercado de trabalho daquela profissão (Di PIETRO, 2007). Mesmo após o ingresso em dado curso, os estudante analisam o mercado de trabalho do curso escolhido e em relação aos demais (McMILLAN, 2005). Assim, a mudança de curso pode então ocorrer quando se criam melhores expectativas quanto à carreira de outro curso (McMILLAN, 2005).

A fim de se categorizar os cursos em níveis de concorrência, realizou-se uma pesquisa documental nos editais dos concursos vestibulares do período de 2012 a 2015 da UnB. Isso possibilitou categorizar os cursos em conformidade com as demandas de candidato por vaga em quatro grupos: alta, intermediária-alta, intermediária-baixa e baixa concorrências. A distribuição entre esses grupos deu-se entre os quartis das médias de demanda candidato por vaga. $O$ quadro 7 informa a categorização dos cursos entre esses grupos.

\begin{tabular}{|c|c|}
\hline $\begin{array}{c}\text { Concorrência nos } \\
\text { vestibulares }\end{array}$ & Cursos de Graduação \\
\hline Alta concorrência & $\begin{array}{l}\text { Medicina, Direito - Diurno, Engenharia Civil, Odontologia, Psicologia, Direito - } \\
\text { Noturno, Arquitetura e Urbanismo - Diurno, Relações Internacionais, Medicina } \\
\text { Veterinária, Comunicação Social, Nutrição, Design, Ciências Biológicas - } \\
\text { Diurno, Engenharia Mecânica, Arquitetura e Urbanismo - Noturno, Ciência da } \\
\text { Computação, Enfermagem (Darcy Ribeiro), Engenharia da Computação, } \\
\text { Arquivologia, Engenharia de Produção, Engenharia Química, Geologia. }\end{array}$ \\
\hline $\begin{array}{l}\text { Intermediária-alta } \\
\text { concorrência }\end{array}$ & $\begin{array}{l}\text { Administração - Diurno, Engenharia Mecatrônica, Engenharia Elétrica, } \\
\text { Ciências Econômicas, Ciência Política, Engenharia Ambiental, Administração - } \\
\text { Noturno, Gestão de Políticas Públicas, Enfermagem (Ceilândia), Artes Cênicas } \\
\text { História - Diurno, Fisioterapia, Letras - Tradução - Inglês, Educação Física, } \\
\text { Biotecnologia, História - Noturno, Ciências Biológicas - Noturno, Letras - } \\
\text { Português Diurno, Ciências Contábeis - Diurno, Ciências Contábeis - Noturno. }\end{array}$ \\
\hline
\end{tabular}


Continuação

\begin{tabular}{|c|c|}
\hline $\begin{array}{l}\text { Concorrência nos } \\
\text { vestibulares }\end{array}$ & Cursos de Graduação \\
\hline $\begin{array}{l}\text { Intermediária-baixa } \\
\text { concorrência }\end{array}$ & $\begin{array}{l}\text { Física - Diurno, Química - Diurno, Serviço Social - Noturno, Engenharia } \\
\text { (FGA), Serviço Social - Diurno, Agronomia, Ciências Sociais, Artes Plásticas, } \\
\text { Engenharia de Redes de Comunicação, Farmácia (Darcy Ribeiro) - Diurno, } \\
\text { Matemática - Diurno, Biblioteconomia, Pedagogia - Noturno, Computação, } \\
\text { Letras - Português Noturno, Fonoaudiologia, Matemática - Noturno, Pedagogia } \\
\text { - Diurno, Geografia, Filosofia - Diurno, Engenharia Florestal. }\end{array}$ \\
\hline Baixa concorrência & $\begin{array}{l}\text { Farmácia (Darcy Ribeiro) - Noturno, Teoria Crítica e História da Arte, Física - } \\
\text { Noturno, Música - Noturno, Ciências Ambientais, Química - Noturno, Filosofia } \\
\text { - Noturno, Química Tecnológica, Turismo, Farmácia (Ceilância) - Diurno, } \\
\text { Geofísica, Estatística, Museologia, Gestão Ambiental, Letras Espanhol - } \\
\text { Noturno, Gestão em Saúde Coletiva (Darcy Ribeiro), Terapia Ocupacional, } \\
\text { Música - Diurno, Gestão Agronegócio (Darcy Ribeiro), Gestão de Saúde } \\
\text { Coletiva (Ceilândia), Ciências Naturais - Diurno, Gestão Agronegócio } \\
\text { (Planaltina). }\end{array}$ \\
\hline
\end{tabular}

Quadro 7 Categorização dos cursos conforme demanda nos vestibulares da UnB

Fonte: Editais dos vestibulares da UnB do período de 2012 a 2015

Com os pares ou conjuntos de cursos listados e cada um categorizado quanto à concorrência nos concursos vestibulares, quantificou-se as migrações entre eles com auxílio de tabelas dinâmicas do Microsoft Excel. Dessa forma, foi construída a coluna de "Direção dos fluxos de Transferências Internas" da tabela 8, a qual indica a direção das transferências entre os cursos de graduação.

A seta sai do curso de origem e aponta para o curso de destino e o número ao lado dela quantifica esse movimento. Por exemplo, ao nível 10.000 o par de cursos mais similares foi Comunicação Social e Letras (diurno), sendo que nessa interação houve a migração de 26 transferências de Letras (diurno) para Comunicação Social e 3 transferências de Comunicação Social para Letras (diurno), no período analisado no estudo.

Tabela 7 Migrações entre pares ou conjuntos de cursos via transferência interna

\begin{tabular}{|c|l|c|l|c|c|c|}
\hline \multirow{2}{*}{$\begin{array}{c}\text { Nível } \\
\text { (level) }\end{array}$} & \multicolumn{4}{|c|}{ Pares ou Conjuntos de cursos de graduação } \\
mais expressivos & $\begin{array}{c}\text { Direção dos } \\
\text { fluxos de } \\
\text { Transferência } \\
\text { s Internas }\end{array}$ \\
\cline { 2 - 7 } & Curso de Graduação & $\begin{array}{c}\text { Demanda em } \\
\text { vestibulares }\end{array}$ & Curso de Graduação & $\begin{array}{c}\text { Demanda em } \\
\text { vestibulares }\end{array}$ & $\begin{array}{c}26 \leftarrow \\
\rightarrow 03\end{array}$ \\
\hline 10.0000 & Comunicação Social & Alta & Letras (diurno) & Inter. Alta & $\begin{array}{c}25 \leftarrow \\
\rightarrow 01\end{array}$ \\
\hline 9.0000 & Psicologia & Alta & Pedagogia (diurno) & Inter. Baixa & Inter. Baixa & $\begin{array}{c}14 \leftarrow \\
\rightarrow 03\end{array}$ \\
\hline 8.5000 & Ciência Política & Inter. Alta & Ciências Sociais & Inter. Baixa & $\begin{array}{c}15 \leftarrow \\
\rightarrow 00\end{array}$ \\
\hline 7.5000 & Engenharia Mecânica & Alta & Engenharia (FGA) & Inter. Baixa & $\begin{array}{c}12 \leftarrow \\
\rightarrow 01\end{array}$ \\
\hline 6.5000 & Ciência da Computação & Alta & Computação &
\end{tabular}


Continuação

\begin{tabular}{|c|c|c|c|c|c|}
\hline 5.5000 & Odontologia & Alta & Gestão de Saúde Coletiva & Baixa & $\begin{array}{l}11 \leftarrow \\
\rightarrow 00\end{array}$ \\
\hline 5.0000 & Geologia & Alta & Geofísica & Baixa & $\begin{array}{l}10 \leftarrow \\
\rightarrow 00\end{array}$ \\
\hline \multirow{2}{*}{4.5000} & Engenharia da Computação & Alta & Engenharia Elétrica & Inter. Alta & $\begin{array}{l}04 \leftarrow 05 \\
\rightarrow 05\end{array}$ \\
\hline & Letras - Português (diurno) & Baixa & Letras - Espanhol & Inter. Alta & $\begin{array}{l}07 \leftarrow 02 \\
\rightarrow 02\end{array}$ \\
\hline \multirow{2}{*}{3.7500} & Relações Internacionais & Alta & Letras - Português (diurno) & Inter. Alta & $\begin{array}{l}10 \leftarrow \\
\rightarrow 00\end{array}$ \\
\hline & Relações Internacionais & Alta & Comunicação Social & Alta & $\begin{array}{l}03 \leftarrow \\
\rightarrow 03\end{array}$ \\
\hline 3.5000 & Engenharia de Civil & Alta & Engenharia de Produção & Alta & $\begin{array}{l}03 \leftarrow \\
\rightarrow 04\end{array}$ \\
\hline \multirow{2}{*}{3.0000} & Design & Alta & Artes Plásticas & Inter. Baixa & $\begin{array}{l}06 \leftarrow \\
\rightarrow 00\end{array}$ \\
\hline & Engenharia Mecânica & Alta & Engenharia Mecatrônica & Inter. Alta & $\begin{array}{l}08 \leftarrow 0 \\
\rightarrow 00\end{array}$ \\
\hline \multirow{3}{*}{2.7500} & Enfermagem (Darcy Ribeiro) & Alta & Gestão de Saúde Coletiva & Baixa & $\begin{array}{l}00 \leftarrow 02 \\
\rightarrow 02\end{array}$ \\
\hline & Odontologia & Alta & Enfermagem (Darcy Ribeiro) & Alta & $\begin{array}{l}09 \leftarrow 0 \\
\rightarrow 00\end{array}$ \\
\hline & Odontologia & Alta & Gestão de Saúde Coletiva & Baixa & $\begin{array}{l}11 \leftarrow \\
\rightarrow 00\end{array}$ \\
\hline \multirow{4}{*}{2.5000} & Enfermagem (FCE) & Inter. Alta & Saúde Coletiva & Baixa & $\begin{array}{l}05 \leftarrow \\
\rightarrow 00\end{array}$ \\
\hline & Administração (noturno) & Inter. Alta & Gestão do Agronegócio & Baixa & $\begin{array}{l}05 \leftarrow 0 \\
\rightarrow 00\end{array}$ \\
\hline & Estatística & Baixa & Matemática (diurno) & Inter. Baixa & $\begin{array}{l}04 \leftarrow 02 \\
\rightarrow 02\end{array}$ \\
\hline & Engenharia Química & Alta & Química & Inter. Baixa & $\begin{array}{l}01 \leftarrow 02 \\
\rightarrow 02\end{array}$ \\
\hline \multirow{4}{*}{2.0000} & Ciências Econômicas & Inter. Alta & Ciências Contábeis & Inter. Alta & $\begin{array}{l}05 \leftarrow 03 \\
\rightarrow 03\end{array}$ \\
\hline & Arquivologia & Alta & Museologia & Baixa & $\begin{array}{l}04 \leftarrow 00 \\
\rightarrow 00\end{array}$ \\
\hline & Direito & Alta & Gestão de Políticas Púbicas & Inter. Alta & $\begin{array}{l}03 \leftarrow \\
\rightarrow 02\end{array}$ \\
\hline & Ciências Biológicas (diurno) & Alta & Medicina Veterinária & Alta & $\begin{array}{l}01 \leftarrow 03 \\
\rightarrow 03\end{array}$ \\
\hline
\end{tabular}

Fonte: Elaboração própria a partir de dados da Universidade de Brasília

Conforme a última coluna da tabela 8 , é possível se perceber uma tendência de migração de alunos de cursos menos concorridos rumo a outros mais concorridos, com base na direção dos fluxos das transferências internas. As poucas exceções foram destacadas na tabela pela cor cinza. Esses indícios de ponte de acesso ou trampolim entre as migrações dos cursos de graduação via transferências internas corroboram, dessa maneira, com o Relatório da Comissão Especial de Estudos sobre Evasão nas Universidades Públicas Brasileiras (BRASIL, 1997) e com o estudo de Cunha, Tunes e Silva (2001).

De acordo com Almeida (2015), a escolha do curso no ensino superior pode estar relacionada ao tipo de escola frequentada pelo aluno, havendo relação entre a 
condição social e a escolha da carreira (BRAGA; PEIXOTO; BOGUTCHI, 2001; ZAGO, 2006). Segundo esses autores, cursos mais prestigiados são mais demandados por alunos oriundos de escolas privadas, não se observando essa tendência entre alunos de escolas públicas devido à falta de competitividade nos exames de admissão (ZAGO, 2006).

Apesar de as transferências internas analisadas na UnB não exigirem a realização de provas de seleção e da maior presença de alunos provindos de escolas públicas na Universidade devido à política de cotas para a rede pública de ensino, $68 \%$ das mudanças de curso foram realizadas por alunos provenientes de escolas privadas. Havia expectativa de maior participação de alunos provenientes de escolas públicas, embora a maior recorrência de alunos oriundos de escolas privadas possa estar relacionada à maior proporção desses estudantes na população de universitários da UnB.

Como resultado das transferências internas, as vagas ociosas dos cursos mais concorridos foram mais preenchidas do que aquelas de cursos menos concorridos, os quais passaram a somar as vagas ociosas ofertadas para o processo de transferência interna com as vagas desocupadas provenientes das saídas de alunos transferidos. Abordando o ensino superior de instituições privadas, Sousa (2013) e Almeida (2015) constataram que não faltam vagas no ensino superior, mas sim estudantes. Essa lacuna pode estar relacionada à dificuldade dos estudantes alcançarem o ensino superior, o que é uma realidade no contexto brasileiro. $E$, entre aqueles que chegam ao ensino superior, o interesse em determinados cursos pode canalizar a maior busca por uns em detrimento de outros.

Se por um lado há cursos com demanda acima da quantidade ofertada de vagas, por outro lado, há também aqueles com oferta acima da procura. Dessa forma, as causas do não preenchimento das vagas de alguns cursos parecem estar mais relacionadas a um descompasso na oferta de vagas do que com os fatores tradicionalmente apontados como motivos de evasão no ensino superior. Ou seja, os motivos que levam à evasão de um estudante que ingressou no curso pretendido podem ser bem diversos daqueles que levam à saída de um curso indesejado (VRIES et al., 2011).

Nesse ínterim, a situação de ingresso em curso não pretendido parece se agravar quando observado que historicamente no ensino superior "a maior oferta de vagas nem sempre ocorreu nas áreas onde o crescimento da procura foi mais 
significativo" (BRAGA; PEIXOTO; BOGUTCHI, 2001, p. 134), o que potencialmente contribui para a ociosidade de vagas. Por vagas ociosas, pode-se entender a diferença entre o quantitativo de vagas ofertadas que são autorizadas e a efetiva quantidade de ingressantes (SOUSA, 2013).

Ou seja, apesar de a expectativa ser a diplomação, nem sempre os objetivos e ambições do estudante concorrem para esse fim (BAREFOOT, 2004). O ingresso na universidade é motivado por diferentes interesses, motivações e, consequentemente, variados níveis de comprometimento quanto ao desempenho e à conclusão do curso por parte do aluno (TINTO, 1973; BAREFOOT, 2004). Reconhecendo a importância e contribuição social das variadas profissões, as preferências e anseios dos estudantes também deveriam ser consideradas quando da oferta de vagas no ensino superior. É razoável se pensar que a oferta de vagas de um determinado curso fosse flexibilizada para se acompanhar a demanda dos estudantes. A adoção dessa prática poderia contribuir para a redução do estoque de vagas ociosas em alguns cursos. 


\section{CONCLUSÕES}

O presente estudo teve como objetivo geral descrever como se estabeleceram as transferências internas entre os cursos de graduação da Universidade de Brasília - UnB, entre o período do primeiro semestre de 2012 ao primeiro semestre de 2016. As transferências internas são normatizadas por editais específicos semestrais. Dessa forma, foram abordados 9 editais. Quanto às regras desses editais para a transferência interna, não foram detectadas alterações entre eles. Contabilizaram-se 1.050 transferências internas no período.

A análise de rede social pode auxiliar na melhor compreensão da evasão, pois realça como as interações entre os atores de uma rede se estabelecem, especialmente quanto ao contexto da evasão de curso no ensino superior. As situações de mudança de curso ou troca de instituição de ensino superior diferem-se daquela relativa ao abandono permanente do ensino superior (STRATTON et al. 2008; HOVDHAUGEN, 2011).

De modo contrário às metodologias que consideram a mudança de curso como evasão necessariamente em sentido negativo, a exemplo de Souza e Toassei (2015) que consideram a mudança de curso como geradora de vagas ociosas, a análise de redes sociais pode revelar que a transferência interna é apenas uma dança das cadeiras entre vagas já ociosas dentro de uma grande área de conhecimento. Nesse sentido, não se trata de gerar ociosidade, mas sim possibilitar permuta entre cursos, o que pode aumentar a probabilidade de diplomação (ORTIZ; DEHON, 2013). Segundo Veloso e Almeida (2012), a mudança de curso pode ser considerada uma evasão em sentido positivo, pois pode ser um redirecionamento mais maduro do estudante acerca sua formação.

As evidências do presente estudo vão ao encontro dos estudos de Velloso e Cardoso (2008) e Vries et al. (2011) no que concerne à constatação de que parte dos casos considerados como evasão refere-se, em verdade, à transferência interna de curso. Dessa maneira, conforme ressaltado por Gomes et al. (2010, p. 10), "a evasão universitária brasileira sinaliza não só os equívocos na orientação profissional dos estudantes, como também representa um ônus para a sociedade, pela ocupação indevida das vagas tão escassas, sobretudo nas universidades públicas, e pelo desperdício financeiro que acarreta”. 
As constatações obtidas pela investigação acerca do primeiro objetivo específico revelaram que a rede de transferência interna é protagonizada por alguns cursos específicos, seja em relação àqueles em que ocorrem considerável fluxo de saída, seja em relação aos que recepcionam uma proporção mais significativa de transferidos internamente. Entre os cursos que mais perdem alunos por conta da transferência interna, foram registrados Letras - Português (diurno), Ciências Sociais, Engenharia (FGA) e Pedagogia (diurno). Entre os cursos mais buscados por aqueles que reoptaram de curso no período analisado, citam-se: Psicologia, Comunicação Social, Engenharia Mecânica e Engenharia de Produção.

Investigando-se os reflexos das transferências internas nos fluxos entre os turnos (diurno e noturno) e entre os campi da Universidade de Brasília, não foram encontrados indícios significativos da utilização da transferência interna entre cursos distintos como alternativa à mudança de turno. É válido salientar que a Universidade de Brasília possui edital próprio destinado às mudanças de turnos, dentro de um mesmo curso de graduação. Quanto o reflexo na mudança de campus, constatou-se uma preponderância de transferências internas da UnB Gama rumo às engenharias dos campus Darcy Ribeiro (Plano Piloto).

Em relação ao segundo objetivo específico, os resultados das transferências internas na Universidade de Brasília no período do 1/2012 ao 1/2016 deixaram a entrever que o estudante, apesar de indeciso quanto ao curso, possui como certa a área de estudo que pretende seguir. Ou seja, por meio do instrumental de análise de redes sociais, observou-se que as mudanças de curso interagem nos limítrofes de grandes áreas de conhecimento, tais como aquelas adotadas no estudo: i) Ciências Agrárias, Exatas e Engenharias; ii) Ciências Humanas, Letras e Artes e iii) Ciências Biológicas e da Saúde.

A criação de mecanismos de bonificação na média ponderada utilizada como base à classificação dos estudantes que pretendem mudar de curso entre as vagas ociosas dos editais de transferência interna apenas reforçaria o que já acontece naturalmente na prática, sobremodo aos cursos da grande área de Ciências Agrárias, Exatas e Engenharias. No que concerne ao terceiro objetivo específico, um olhar para as interações dentro dessas grandes áreas de conhecimento permitiu se constatar um sintonia quanto ao fluxo de migração entre os cursos de graduação no processo de transferência interna. Citam-se, por exemplo, a expressiva saída de alunos de Letras (diurno) para Comunicação Social; da Pedagogia (diurno) para a 
Psicologia; da Ciências Sociais para Ciência Política; da Engenharia (formação básica da FGA) para Engenharia Mecânica; da Computação para Ciência da Computação, entre outros.

Em busca de um padrão que explicasse a significância dessas interações, notou-se um movimento de saída de cursos menos concorridos para cursos mais concorridos, conforme as demandas de candidato por vaga registradas nos exames vestibulares da Universidade de Brasília do mesmo período. Os pares ou conjuntos de cursos com interações mais nítidas entre si, conforme listado no estudo, corroboram a constatação de que, mesmo diante indícios de que as mudanças de cursos ocorrem sob influência do efeito trampolim, ainda assim, as transferências internas ocorrem entre cursos pertencentes a mesma grande área de conhecimento.

Entre as limitações do estudo, deve-se atentar que a configuração da rede de transferência interna apresentada nesse estudo é um retrato do período analisado. Conforme lembram Silva et al. (2016, p. 110), uma rede é caracterizada "pela habilidade de se fazer e desfazer rapidamente relações". O fato de cursos não se relacionarem na rede de transferência interna apresentada no estudo não significa que eles não estejam relacionados em outros contextos, a exemplo das mudanças de cursos via novo vestibular.

O recorte longitudinal, por sua vez, não permitiu um panorama completo de todo o histórico de transferências internas da UnB. Ademais, dados anteriores ao período estudado não estavam disponibilizados na página eletrônica da Secretaria de Administração Acadêmica - SAA. E entre os dados disponibilizados, constatouse erros materiais quanto à duplicidade de matrículas atribuídas a diferentes alunos, registros de nomes com grafia errada, assim como erros na designação do curso de origem.

Conforme evidenciado, a exemplo de outras instituições de ensino superior, sugere-se a implementação de mecanismos que colaborem para o alcance da finalidade das mudanças de cursos: preencher vagas ociosas. Conforme os editais analisados e com base nos dados utilizados, o processo de transferência interna permite a inscrição em mais de uma opção de curso, com os devidos pagamentos. Ocorre que, ao ser selecionado para mais de uma opção, não existe um mecanismo de prioridade de opção ou de choque para evitar que duas vagas de cursos distintos fiquem atribuídas à escolha do aluno aprovado. Além do mais, o processo de 
transferência interna não é irreversível, ou seja, o aluno mesmo sendo selecionado pode optar por permanecer no curso de origem.

Quanto ao desempenho no curso de origem, a literatura sublinha que antes de mudar de curso o desempenho é insatisfatório (MCMILLAN, 2005). Assim, surge o dilema se a mudança de curso se deve ao rendimento insatisfatório e atrasos no fluxo das disciplinas em determinado curso (OQUENDO, 2008) ou, pelo fato de pretender mudar de curso, o aluno não se dedica adequadamente às disciplinas do curso de origem. Estudos nesse sentido não seriam viáveis com os dados de mudança de curso da UnB, pois o aluno que se inscreve para mudar de curso é avaliado apenas quanto às disciplinas cursadas do curso pretendido.

Entre recomendações de estudos futuros, sugere-se a abordagem da mudança de curso sob a ótica da renda. Qual o perfil, em termos de renda, do estudante que muda de curso via transferência interna? Há indícios na literatura de que o estudante que possui maior renda está mais propenso ao matching com a carreira que mais se encaixa às expectativas e aos anseios dele, considerando-se os suportes financeiro e educacional recebidos para se preparar para o vestibular (SAMPAIO et al. 2011), mesmo após tentativas frustradas de aprovação (NOGUEIRA, 2004). Não apenas durante o processo de seleção do vestibular, mas ao longo da trajetória escolar, esses estudantes recebem todo o suporte para que, no momento de decisão, convirjam desejos e projetos com o real poder de escolha (DUBET, 1994).

Contribuindo à literatura acerca de evasão no ensino superior e em complemento às evidências do presente estudo, sugere-se uma pesquisa abordando quais os motivos e influências que levam alunos a mudarem de curso, sob a perspectiva deles. Por fim, detectar a taxa de diplomação de alunos que mudam de curso pode auxiliar a melhor compreender o fenômeno e fornecer insumos às políticas que regulamentam a mudança de curso na Universidade de Brasília. 


\section{REFERÊNCIAS}

ALEJANDRO, V.A.; NORMAN, A. G. Manual Introdutório à Análise de Redes Sociais. UAEM - Universidad Autonoma del Estado de Mexico. 2005.

ALMEIDA, S. S. Vagas ociosas no ensino superior brasileiro: uma análise dos governos Fernando Henrique Cardoso e Luiz Inácio Lula da Silva e suas repercussões nos anos posteriores. In: XV Colóquio Internacional de Gestão Universitária - CIGU, 2015, Anais... Mar del Plata, 2015.

ANDRIOLA, W. B.; ANDRIOLA, C. G.; MOURA, C. P. Opiniões de docentes e de coordenadores acerca do fenômeno da evasão discente dos cursos de graduação da Universidade Federal do Ceará. Ensaio: aval. pol. públ. Educ., Rio de Janeiro, v. 14, n. 52, pp. 365-383, jul./set., 2006.

BARBASTEFANO, R. G.; SOUZA, C.; COSTA, J. S.; TEIXEIRA, P. M. Impactos dos nomes nas propriedades de redes sociais: um estudo em rede de coautoria sobre sustentabilidade. Perspectivas em Ciência da Informação, v. 18, n. 3, p. 78-95, jul./set. 2013.

BARDAGI, M. P.; HUTZ, C. S. Não havia outra saída: percepções de alunos evadidos sobre o abandono do curso superior. Psico-USF, v. 14, n. 1, pp. 95-105, jan./abr., 2009.

BAREFOOT, B. O. Higher education's revolving door: confronting the problem of student drop out in US colleges and universities. Open Learning, vol. 19, n. 1, 2004.

BRAGA, M. M.; PEIXOTO, M. C.; BOGUTCHI, T. F. Tendências da demanda pelo ensino superior: estudo de caso da UFMG. Cadernos de Pesquisa, n. 113, p. 129-152, jul. 2001

BRAGA, M. M.; CARDEAL, Z. L.; PINTO, C. O. B. M. Perfil Sócio-econômico dos alunos, repetência e evasão no curso de Química da UFMG. Química Nova, São Paulo, v. 05/96, n.5/96, p. 1-18, 1996.

BRASIL. Diplomação, retenção e evasão nos cursos de graduação em instituições de ensino superior públicas. Relatório da Comissão Especial de Estudos sobre Evasão nas Universidades Públicas Brasileiras. Brasília, DF:

ANDIFES/ABRUEM/SESU/MEC, 1997.

Relatório de Gestão do exercício de 2015. Decanato de Planejamento e Orçamento - DPO da Universidade de Brasília. 2015. Disponível em: http://www.dpo.unb.br/documentos/Relatorio_Gestao_2015.pdf>. Acesso em 03 de set. 2016

Aonde a UnB pode te levar. Guia do calouro 10/2014. Decanato de Graduação; Diretoria Técnica de Graduação - Brasília: Editora UnB, 216 p. 2014. 
.MEC. Ministério da Educação. Tabelas de Áreas de Conhecimento/Avaliação.

Disponível em: <http://www.capes.gov.br/avaliacao/ instrumentos-de-apoio/tabela-deareas-do-conhecimento-avaliacao>. Acesso em 24 de set. de 2016.

BORGATTI, S. P. Netdraw network visualization. Analytic Technologies: Harvard, MA, 2002

; EVERETT, M.G.; FREEMAN, L.C. Ucinet 6 for Windows: Software for Social Network Analysis. 2002

; JOHNSON, J.C. Analyzing Social Networks. Sage Publications, 2013

BRITO, M. I. L. Implementação do REUNI na UnB (2008-2011): limites na ampliação de vagas e redução de evasão. 2013. 254f. Dissertação (Mestrado em Educação) Faculdade de Educação, Universidade de Brasília, Brasília.

CUNHA, A. M.; TUNES, E.; SILVA, R. R. Evasão do curso de química da Universidade de Brasília: a interpretação do aluno evadido. Química Nova, vol. 24, n. 1, pp. 262-280, 2001.

CUNHA, P. J. M.; SPRITZER, I. M. P; WILDHAGEN, V. Evasão no Ensino Superior de Engenharia no Brasil: Um Estudo de Caso no CEFET/RJ. In: Congresso Brasileiro de Educação em Engenharia - COBENGE, 2012, Anais...Belém-PA, 2012.

DI PIETRO, G. Regional labour market conditions and university dropout rates: evidence from Italy. Regional Studies, vol. 40, n. 6, pp. 617-630, 2007.

DIAS, E. C. M.; THEÓPHILO, C. R.; LOPES, M. A. S. Evasão no ensino superior: estudo dos fatores causadores da evasão no curso de Ciências Contábeis da Universidade Estadual de 16 Montes Claros - Unimontes - MG. In: Congresso USP de iniciação científica em contabilidade, São Paulo. Anais... São Paulo: Éxito Editora, 2010.

DIAS SOBRINHO, J. Apresentação. In: Dilvo Ristoff. (Org.). Universidade em Foco. Reflexões sobre a Educação Superior, pp. 15-19. 1999.

DUBET, F. O que é uma escola justa? Tradução de Édi Gonçalves de Oliveira e Sérgio Cataldi. Cadernos de Pesquisa, v. 34, n. 123, pp. 539-555, set;/dez., 2004.

DULLIUS, R.; CYRNE, C. C. S. Mapeamento da evasão acadêmica: um estudo aplicado à Univates. In: X Colóquio Internacional sobre Gestão Universitária na América do Sul, Mar del Plata. Anais....Mar del Plata, 2010.

EVERTON, S. F. Disrupting dark networks. Naval Postgraduate School, Monterey, California. Cambridge, 2012.

FAZITO, D. Redes Sociais e Migração: mito e realidade. In: XIII Encontro da Associação Brasileira de Estudos Populacionais, Anais... Ouro Preto, 2002.

FAWCETT, J. T. Networks, linkages and migration systems. International Migration Review, vol. 23, n. 3, 1989. 
FERREIRA, T; VITORINO FILHO, V. A. Teoria de redes: uma abordagem social. Revista Conteúdo, Capivari, v. 1, n. 3, jan/jul. 2010.

FIEGEHEN, L. E. G. Repitencia y deserción universitaria en América Latina. In: Instituto Internacional de la Unesco para la Educación Superior en América Latina y el Caribe lesalc (Org.). Informe sobre la educación superior en América Latina y el Caribe 2000-2005. Caracas, 2006.

FIGUEIREDO, D. R. Introdução a Redes Complexas. In: SOUZA, A. F.; MEIRA JUNIOR, W. (Org.). Atualizações em Informática. Rio de Janeiro: PUC-Rio, p. 303-358, 2011

FREIRE, P. Para onde foi meu aluno evadido?, 2015. Disponível em: < http://www.hoper.com.br/single-post/2015/07/20/PARA-ONDE-FOI-MEU-ALUNOEVADIDO>. Acesso em: 01 ago. 2016.

GIL, A. C. Métodos e técnicas de pesquisa social. 2. ed. São Paulo: Atlas, 1989.

GOMES, M. J; MONTEIRO, M.; DAMASCENO, A. M.; ALMEIDA, T. J. S.; CARVALHO, R. B. Evasão acadêmica no Ensino Superior: estudo na área da Saúde. Revista Brasileira de Pesquisa em Saúde, vol. 12, n. 1, pp. 6-13, 2010.

GÓMEZ, M. R. F.; TORRES, J. C. Discutindo o acesso e a permanência no ensino superior no contexto do SISU. Revista ORG \& DEMO, vol. 16, n. 1, pp. 69-88, jan./jun., 2015.

GUIMARÃES, F. J. Z.; MELO, E. S. Diagnóstico utilizando análise de redes sociais. 2005. 51 f. Monografia (Especialização em Engenharia de Produção) - Universidade Federal do Rio de Janeiro, Rio de Janeiro, 2005.

GUIZONI, L. D.; TELES, M. M. R. Escolha e re-escolha profissional: Um estudo sobre estudantes universitários noturnos. Em M. C. P. Lassance, A. C. Paradiso, M. P.

Bardagi, M. Sparta, \& S. L. Frischenbruder (Orgs.), Intervenção e compromisso social: Orientação profissional - teoria e técnica, vol. 2, pp. 291-301, 2005

HAIR, J. F. Análise multivariada de dados. 5. ed. Porto Alegre: Bookman, 688 p., 2005

HANNEMAN, R. A.; RIDDLE, M. Introduction to social network methods. Riverside: University of Califórnia, 2005.

HOTZA, M. A. S.; LUCCHIARI, D. H. P. S. A re-escolha profissional dos vestibulandos da UFSC de 1997. Revista da ABOP, 2, pp. 97-110, 1998.

HOVDHAUGEN, E. Do structured study programmes lead to lower rates of dropout and student transfer from university? Irish Educational Studies, vol. 30, n. 2, pp. 237-251, jun., 2011

HUISMAN, M.; DUIJN, M. A. J. Software for Social Network Analysis. In: CARRINGTON, P. J; SCOTT, J.; WASSERMAN, S. Models and methods in social network analysis. Cambridge, $9^{\text {th }}$ printing, 2012. 
KADUSHIN, Charles. Understanding social networks: theories, concepts, and findings. New York: Oxford University Press, 252 p., 2012

KIPNIS, B.; BAREICHA, P. Índices de evasão dos cursos na Universidade de Brasília e suas perspectivas. Caderno Linhas Críticas, Brasília, n.5/6, p.131-145, jul./jul.1997.

LIMA, L.; MEIRINHOS, M. Aplicação da análise sociométrica de redes sociais a fóruns de discussão de comunidades virtuais. In: ENCONTRO INTERNACIONAL TIC E EDUCAÇÃO, 1. Bragança. Anais... Bragança: IPB, 545-550, 2010.

LOBO, M. B. C. M. Panorama da evasão no ensino superior brasileiro: aspectos gerais das causas e soluções. ABMES Cadernos - Associação Brasileira de Mantenedoras de Ensino Superior, n. 25, pp. 9-58, 2012.

MAGALHÃES, M. O.; REDIVO, A. B. Re-opção de curso e maturidade vocacional. Revista da ABOP, Florianópolis, v. 3, n.1, pp. 7-28, 1998.

MARINGE, F. University and course choice: implications for positioning, recruitment and marketing. International Journal of Educational Management, vol. 20, n. 6, pp. 466479, 2006.

MALHOTRA, N. K. Pesquisa de marketing: uma orientação aplicada. 4. ed. Porto Alegre: Bookman, 720 p., 2008

MARTELETO, R. M. Análise de redes sociais - aplicação nos estudos de transferência da informação. Revista Ciência da Informação, v. 30, n. 1, pp. 71-81, jan/abr. 2001

MATOS, R. A. Comparação de metodologias de análise de agrupamentos na presença de variáveis categóricas e contínuas. 2007. 156 f. Dissertação (PósGraduação em Estatística) - Universidade Federal de Minas Gerais, Minas Gerais 2007.

MCMILLAN, J. Course change and attrition from higher education. LSAY Research Reports. Longitudinal surveys of Australian youth research report, n. 30, jun., 2005

METZ, J.; CALVO, R.; SENO, E. R. M.; ROMERO, R. A. F.; LIANG, Z. Redes complexas: conceitos e aplicações. Relatórios Técnicos do ICMC, n. 290, São Carlos, jan. 2007

MEYER, M; MARX, S. Engineering dropouts: a qualitative examination of why undergraduates leave engineering. Journal of Engineering Education, vol. 103, n. 4, pp. 525-548, 2014.

NEWMAN, M. E. J. The structure and function of complex networks. SIAM Review, vol. 45, n. 2, pp. 167-256, 2003.

M. E. J. Who is the best connected scientist? A study of scientific coauthorship networks. Complex Networks, pp. 337-370, 2004

NOGUEIRA, M. A. Favorecimento econômico e excelência escolar: um mito em questão. Revista Brasileira de Educação, n. 26, maio/jun./jul./ago., 2004. 
ORTIZ, E. A.; DEHON, C. Roads to sucess in the belgian french community's higher education system: predictors of dropout and degree completion at the Université Libre de Bruxelles. Res High Educ, n. 54, pp. 693-723, 2013

OQUENDO, C. Determinantes de la deserción universitaria en la Facultad de Economía de la Universidad del Rosario. Serie Documentos Borradores de Investigación, n. 95, 2008.

PASCOTTO, S. M. P.; FARINA, M. C.; RODRIGUES, T. H. P. T.; DUGO, J. C. Análise de rede social para mensuração das estruturas formais e informais. Rev. Adm. UFSM, Santa Maria, v. 6, Edição Especial, p. 179-194, mai. 2013

PORTILHO, O.; PEDROZA, A. C. Um estudo da evasão no curso de graduação em física da UnB. Relatório à comissão de graduação do Instituto de Física. Brasília: ago. 2008. Disponível em: http://www.if.ufrgs.br/gra/agenda/relatorio_ a_comissao_de_graduacao.pdf. Acesso em agosto de 2016.

PRELL, C. Social network analysis: history, theory \& methodology. Los Angeles: Sage, p. 263, 2012

REIS, V. W.; CUNHA, P. J. M.; SPRITZER, I. M. P. Evasão no ensino superior de engenharia no Brasil: um estudo de caso no CEFET/RJ. In: Congresso Brasileiro de Educação em Engenharia - COBENGE, 2012, Belém. Anais...Pará, 2012.

RISTOFF, D. I. Universidade em Foco: reflexões sobre a educação superior. Florianópolis: Insular, 1999.

RODRIGUES, H. W. Direito à educação: acesso, permanência e desligamento de alunos do ensino superior. Revista Sequência, n. 52, p. 201-216, jul. 2006

ROVIRA, E. C. La transición de los estudios universitarios: abandono o cambio en el primer año de Universidad. Revista de Investigación Educativa, v. 19, n. 1, pp. 7-35, 2001

SANTOS, N. V. M.; LAGE JUNIOR, M.; RIBEIRO, M. L. L. Evasão no Curso de Engenharia de Produção da Universidade Federal de Goiás - Regional Catalão. ENEGEP. Anais...Fortaleza, CE. 2015.

SBARDELINI, E. T. B. Identidade profissional e opção universitária. Psicologia Escolar e Educacional, Campinas, v. 5, n.1, pp. 95-99, 2001.

SILVA FILHO, R. L. L.; MOTEJUNAS, P. R; HIPÓLITO, O.; LOBO, M. B. C. M. A evasão no ensino superior brasileiro. Cadernos de Pesquisa, v. 37, n. 132, p. 641-659, set./dez., 2007.

SOUSA, J. V. Vagas ociosas na educação superior brasileira no período 2003-2010: novas variáveis em jogo? Tópicos Educacionais, Recife, n. 1, jan./jun., 2013 
SOUZA, J. M.; TOASSI, R. F. C. Evasão na educação superior: estudo de caso do curso noturno de odontologia da Universidade Federal do Rio Grande do Sul. In: Colóquio Internacional de Gestão Universitária, 2014, Florianópolis. XIV Colóquio Internacional de Gestão Universitária - CIGU. A Gestão do Conhecimento e os Novos Modelos de Universidade. Anais... Florianópolis: UFSC, 2015.

STRATTON, L. S.; O'TOOLE, D. M.; WETZEL, J. N. A multinomial logit model of college stopout and dropout behavior. Economics of Education Review, vol. 27, pp. 319-331, 2008.

TINTO, V. Dropout from higher education: a theoretical synthesis of recent research. Review of Educational Research, vol. 45, n.1, pp. 89-125, 1973.

TERRIBILI FILHO, A.; NERY, A. C. B. Ensino superior noturno no Brasil: história, atores e políticas. Revista Brasileira de Política e Administração da Educação - RBPAE, v. 25, n. 1, p. 61-81, jan./abr., 2009

VALORE, L. A., CAVALLET, L. H. R. Escolha e orientação profissional de estudantes de curso pré-vestibular popular. Psicologia \& Sociedade; 24 (2), 354-363, 2012

VARGAS, H. M.; PAULA, M. F. C. A inclusão do estudante-trabalhador e do trabalhadorestudante na educação superior: desafio público a ser enfrentado. Avaliação, v. 18, n. 2, p. $459-485$, jul. 2013

VELLOSO, J.; CARDOSO, C. B. Evasão na educação superior: alunos cotistas e nãocotistas na Universidade de Brasília. In: 31ํㅡ Reunião Anual da ANPEd, 2008, Caxambú. Anais... Rio de Janeiro, 2008.

VRIES, W; ARENAS, P. L.; MUÑOZ, J. F. R.; SALDAÑA, I. H. ¿Desertores o decepcionados? Distintas causas para abandonar los estudios universitarios. Revista de la Educación Superior, vol. XL (4), n. 160, pp. 29-49, oct./dic., 2011.

ZAGO, N. Do acesso à permanência no ensino superior: percursos de estudantes universitários de camadas populares. Revista Brasileira de Educação, v. 11, n. 32, maio/ago., 2006 


\section{Anexo A Categorização dos cursos conforme a concorrência nos exames vestibulares de 201212015}

\begin{tabular}{|c|c|c|c|c|c|}
\hline \multirow{2}{*}{ Cursos de Graduação } & \multicolumn{4}{|c|}{ Demanda - Vestibulares UnB } & \multirow{2}{*}{ Média } \\
\hline & 2/2012 & $2 \% / 2013$ & 2\%/2014 & 2\%/2015 & \\
\hline Medicina & 90,93 & 85,92 & 144,8 & 174,9 & 124,14 \\
\hline Direito - Diurno & 24,15 & 22,63 & 31,69 & 20,24 & 24,68 \\
\hline Engenharia Civil & 25,97 & 22,05 & 28,79 & 16,7 & 23,38 \\
\hline Odontologia & 16,04 & 15,37 & 22,75 & 20,38 & 18,64 \\
\hline Psicologia & 15,33 & 15,7 & 24,41 & 16,86 & 18,08 \\
\hline Direito - Noturno & 15,25 & 20,13 & 19,67 & 14,91 & 17,49 \\
\hline Arquitetura e Urbanismo - Diurno & 17,03 & 13,3 & 17,39 & 16,96 & 16,17 \\
\hline Relações Internacionais & 17,43 & 18,97 & 14,88 & 11,96 & 15,81 \\
\hline Medicina Veterinária & 11,25 & 11,25 & 18,75 & 15,3 & 14,14 \\
\hline Comunicação Social & 13,67 & 11,36 & 17,42 & 12,59 & 13,76 \\
\hline Nutrição & 10,19 & 11,59 & 18,45 & 12,83 & 13,27 \\
\hline Design & 12,44 & 9,8 & 11,43 & 11,55 & 11,31 \\
\hline Ciências Biológicas - Diurno & 9,03 & 9,23 & 13,32 & 9,43 & 10,25 \\
\hline Engenharia Mecânica & 8,38 & 8,75 & 13,14 & 7,35 & 9,41 \\
\hline Arquitetura e Urbanismo - Noturno & 9,17 & 9,65 & 9,5 & 8,81 & 9,28 \\
\hline Ciência da Computação & 7,53 & 7,53 & 9,61 & 7,96 & 8,16 \\
\hline Enfermagem (Darcy Ribeiro) & 7,34 & 6,8 & 9,61 & 7,96 & 7,93 \\
\hline Engenharia da Computação & 7,06 & 6,85 & 9,21 & 7,39 & 7,63 \\
\hline Arquivologia & 6,26 & 8,93 & 7,62 & 6,65 & 7,37 \\
\hline Engenharia de Produção & 6,4 & 8,85 & 8,32 & 5,86 & 7,36 \\
\hline Engenharia Química & 8,03 & 8,15 & 7,93 & 5 & 7,28 \\
\hline Geologia & 7,69 & 6,72 & 9,23 & 5,06 & 7,18 \\
\hline Administração - Diurno & 7,13 & 6,53 & 8,64 & 5,88 & 7,05 \\
\hline Engenharia Mecatrônica & 7,66 & 5,8 & 8,79 & 5,48 & 6,93 \\
\hline Engenharia Elétrica & 6,47 & 6,45 & 8,46 & 5,96 & 6,84 \\
\hline Ciências Econômicas & 6,23 & 5,08 & 7,85 & 7,14 & 6,58 \\
\hline Ciência Política & 5,4 & 5,68 & 8,38 & 4,89 & 6,09 \\
\hline Engenharia Ambiental & 7,44 & 4,8 & 6,64 & 5,3 & 6,05 \\
\hline Administração - Noturno & 5,44 & 6,78 & 6,31 & 5,35 & 5,97 \\
\hline Gestão de Políticas Públicas & 4,93 & 7,15 & 7,59 & 4,14 & 5,95 \\
\hline Enfermagem (Ceilândia) & 5,15 & 3,8 & 8,59 & 5 & 5,64 \\
\hline Artes Cênicas & 4,1 & 4,38 & 6,76 & 6,71 & 5,49 \\
\hline História - Diurno & 3,84 & 4,83 & 7,04 & 6 & 5,43 \\
\hline Fisioterapia & 5,23 & 4,58 & 6,18 & 5,14 & 5,28 \\
\hline Letras - Tradução — Inglês & 4,06 & 4 & 6,64 & 6,27 & 5,24 \\
\hline Educação Física & 3,33 & 4,26 & 6,79 & 6,04 & 5,11 \\
\hline Biotecnologia & 4,78 & 4,33 & 5,5 & 5,17 & 4,95 \\
\hline História - Noturno & 3,97 & 4,52 & 5,39 & 5,78 & 4,92 \\
\hline Ciências Biológicas - Noturno & 3,47 & 5,3 & 4,93 & 5,83 & 4,88 \\
\hline Letras - Português Diurno & 3,92 & 4,8 & 6,1 & 4,38 & 4,80 \\
\hline Ciências Contábeis - Diurno & 4,61 & 4,35 & 5,23 & 3,98 & 4,54 \\
\hline Ciências Contábeis - Noturno & 4,07 & 3,84 & 5,45 & 4 & 4,34 \\
\hline Física - Diurno & 3,89 & 3,86 & 5,08 & 4,4 & 4,31 \\
\hline Química - Diurno & 3,35 & 3,72 & 5,5 & 4,11 & 4,17 \\
\hline Serviço Social - Noturno & 4,09 & 6,04 & 3,32 & 2,83 & 4,07 \\
\hline
\end{tabular}




\begin{tabular}{|c|c|c|c|c|c|}
\hline Engenharia (FGA) & 3,73 & 4,81 & 4,63 & 3,11 & 4,07 \\
\hline Serviço Social - Diurno & 3,31 & 5,07 & 4 & 3,61 & 4,00 \\
\hline Agronomia & 3,94 & 2,68 & 5,32 & 3,78 & 3,93 \\
\hline Ciências Sociais & 3,44 & 3,03 & 5,35 & 3,73 & 3,89 \\
\hline Artes Plásticas & 3,54 & 3 & 4,3 & 4,69 & 3,88 \\
\hline Engenharia de Redes de Comunicação & 3,28 & 3,63 & 4,54 & 3,78 & 3,81 \\
\hline Farmácia (Darcy Ribeiro) - Diurno & 3,22 & 2.03 & 4,71 & 3,43 & 3,79 \\
\hline Matemática - Diurno & 2,96 & 2,72 & 5,08 & 4,35 & 3,78 \\
\hline Biblioteconomia & 4,34 & 2,83 & 4,32 & 2,87 & 3,59 \\
\hline Pedagogia - Noturno & 3,47 & 4,14 & 4,14 & 2,48 & 3,56 \\
\hline Computação & 3,06 & 3,4 & 3,48 & 3,48 & 3,36 \\
\hline Letras - Português Noturno & 3,28 & 3,78 & 3,11 & 2,96 & 3,28 \\
\hline Fonoaudiologia & $\mathrm{x}$ & 2,57 & 3,92 & 3 & 3,16 \\
\hline Matemática - Noturno & 2,85 & 3,36 & 3 & 3,39 & 3,15 \\
\hline Pedagogia - Diurno & 2,7 & 3,18 & 3,38 & 3,21 & 3,12 \\
\hline Geografia & 2,61 & 2,58 & 4,12 & 3,1 & 3,10 \\
\hline Filosofia - Diurno & 2,66 & 2,98 & 3,54 & 3,17 & 3,09 \\
\hline Engenharia Florestal & 2,8 & 3,08 & 3,56 & 2,79 & 3,06 \\
\hline Farmácia (Darcy Ribeiro) - Noturno & 2,25 & 3 & 3,65 & 3,31 & 3,05 \\
\hline Teoria Crítica e História da Arte & 2,19 & 3,44 & 3,5 & 2,96 & 3,02 \\
\hline Física - Noturno & 2,77 & 3,27 & 2,82 & 3,17 & 3,01 \\
\hline Música - Noturno & 5,05 & $3 ., 38$ & 1,71 & 1,93 & 2,90 \\
\hline Ciências Ambientais & 2,25 & 3 & 3,36 & 2,96 & 2,89 \\
\hline Química - Noturno & 2,38 & 2,82 & 3,82 & 2,44 & 2,87 \\
\hline Filosofia - Noturno & 2,22 & 2,93 & 3,32 & 2,96 & 2,86 \\
\hline Química Tecnológica & 2,92 & 2,59 & 3,32 & 2,39 & 2,81 \\
\hline Turismo & 2,53 & 2,93 & 2,79 & 2,43 & 2,67 \\
\hline Farmácia (Ceilância) - Diurno & 3 & 2,14 & 3,29 & 2 & 2,61 \\
\hline Geofísica & 2,38 & 1,73 & 4 & 2,13 & 2,56 \\
\hline Estatística & 2,03 & 1,9 & 3,32 & 2,61 & 2,47 \\
\hline Museologia & 2,58 & 1,81 & 2,09 & 2,44 & 2,23 \\
\hline Gestão Ambiental & 2,47 & 2,63 & 1,96 & 1,7 & 2,19 \\
\hline Letras Espanhol - Noturno & 2,38 & 2,85 & 1,55 & 1,94 & 2,18 \\
\hline $\begin{array}{l}\text { Gestão em Saúde Coletiva (Darcy } \\
\text { Ribeiro) }\end{array}$ & 2,41 & 2,37 & 1,96 & 1,35 & 2,02 \\
\hline Terapia Ocupacional & 2,23 & 1,36 & 2,06 & 2,04 & 1,92 \\
\hline Música - Diurno & 1,6 & 1,23 & 2,29 & 2,29 & 1,85 \\
\hline Gestão Agronegócio (Darcy Ribeiro) & 1,47 & 1,74 & 1,57 & 1,91 & 1,67 \\
\hline Gestão de Saúde Coletiva (Ceilândia) & 1,52 & 1,23 & 1,52 & 1 & 1,32 \\
\hline Ciências Naturais - Diurno & 1,08 & 1,81 & 1,07 & 0,78 & 1,19 \\
\hline Gestão Agronegócio (Planaltina) & 0,83 & 1,42 & 1,15 & 0,96 & 1,09 \\
\hline
\end{tabular}


Anexo B Cursos de Destino a partir do Campus de Origem

\begin{tabular}{|c|c|}
\hline \multicolumn{2}{|c|}{ CAMPUS DE ORIGEM: DARCY RIBEIRO (PLANO PILOTO) } \\
\hline Curso de Destino & Quantidade \\
\hline Psicologia & 88 \\
\hline Comunicação Social & 80 \\
\hline Administração & 42 \\
\hline Ciências Econômicas & 35 \\
\hline Engenharia de Produção & 35 \\
\hline Relações Internacionais & 34 \\
\hline Engenharia Mecânica & 34 \\
\hline Arquitetura e Urbanismo & 30 \\
\hline Odontologia & 30 \\
\hline Ciência Política & 28 \\
\hline Letras & 26 \\
\hline Engenharia Elétrica & 25 \\
\hline Matemática & 23 \\
\hline Direito & 23 \\
\hline Ciência da Computação & 22 \\
\hline Engenharia Civil & 20 \\
\hline Geologia & 19 \\
\hline História, Ciências Biológicas, Ciências Sociais & 17 \\
\hline Ciências Contábeis & 16 \\
\hline Nutrição e Arquivologia & 14 \\
\hline Letras - Tradução - Inglês & 13 \\
\hline Design e Engenharia Química & 12 \\
\hline Engenharia de Computação & 11 \\
\hline Estatística & 10 \\
\hline Medicina Veterinária & 9 \\
\hline Física e Gestão de Políticas Públicas & 8 \\
\hline $\begin{array}{l}\text { Engenharia Ambiental, Artes Plásticas e } \\
\text { Engenharia Mecatrônica }\end{array}$ & 7 \\
\hline Pedagogia & 6 \\
\hline $\begin{array}{l}\text { Enfermagem (Darcy Ribeiro), Educação Física, } \\
\text { Química e Computação }\end{array}$ & 4 \\
\hline $\begin{array}{l}\text { Eng. de Redes de Comunicação, Eng. Florestal, } \\
\text { Biotecnologia, Letras-Tradução Espanhol, Gestão } \\
\text { em Saúde Coletiva }\end{array}$ & 3 \\
\hline $\begin{array}{l}\text { Teoria Crítica e História da Arte, Enfermagem } \\
\text { (Ceilândia), Filosofia, Fisioterapia, Biblioteconomia, } \\
\text { Museologia, Engenharia Eletrônica, Música }\end{array}$ & 2 \\
\hline $\begin{array}{l}\text { Serviço Social, Geografia, Química Tecnológica, } \\
\text { Gestão Ambiental, Geofísica, Turismo, } \\
\text { Agronomia, Ciências Ambientais }\end{array}$ & 1 \\
\hline
\end{tabular}




\begin{tabular}{|l|r|}
\hline \multicolumn{2}{|c|}{ CAMPUS DE ORIGEM: FACUDADE UnB CEILÂNDIA } \\
\hline \multicolumn{1}{|c|}{ Curso de Destino } & Quantidade \\
\hline Enfermagem (Ceilândia) & 9 \\
\hline Farmácia (Ceilândia) & 6 \\
\hline Odontologia & 5 \\
\hline Fisioterapia & 4 \\
\hline Fonoaudiologia & 2 \\
\hline Nutrição & 2 \\
\hline Psicologia & 2 \\
\hline Administração & 2 \\
\hline Engenharia de Energia & 1 \\
\hline Gestão em Saúde Coletiva & 1 \\
\hline Engenharia Florestal & 1 \\
\hline Comunicação Social & 1 \\
\hline Educação Física & 1 \\
\hline Farmácia (Darcy Ribeiro) & 1 \\
\hline
\end{tabular}

\begin{tabular}{|l|r|}
\hline \multicolumn{2}{|c|}{ CAMPUS DE ORIGEM: FACUDADE UnB CEILÂNDIA } \\
\hline \multicolumn{1}{|c|}{ Curso de Destino } & Quantidade \\
\hline Geologia & 3 \\
\hline Engenharia Mecânica & 2 \\
\hline Engenharia Química & 1 \\
\hline Gestão de Políticas Públicas & 1 \\
\hline Psicologia & 1 \\
\hline Odontologia & 1 \\
\hline Enfermagem (Darcy Ribeiro) & 1 \\
\hline Gestão Ambiental & 1 \\
\hline Engenharia de Computação & 1 \\
\hline Matemática & 1 \\
\hline Biotecnologia & 1 \\
\hline Pedagogia & 1 \\
\hline Artes Plásticas & 1 \\
\hline Ciências Sociais & 1 \\
\hline Ciências Biológicas & \\
\hline
\end{tabular}




\begin{tabular}{|l|r|}
\hline \multicolumn{2}{|c|}{ CAMPUS DE ORIGEM: FACULDADE UnB GAMA } \\
\hline \multicolumn{1}{|c|}{ Curso de Destino } & Quantidade \\
\hline Engenharia Mecânica & 39 \\
\hline Engenharia Elétrica & 25 \\
\hline Engenharia de Produção & 24 \\
\hline Engenharia Aeroespacial & 7 \\
\hline Eng. de Redes de Comunicação & 6 \\
\hline Engenharia de Software & 5 \\
\hline Engenharia Civil & 4 \\
\hline Engenharia Eletrônica, Matemática, Engenharia & 3 \\
Mecatrônica, Engenharia de Energia. & 2 \\
\hline $\begin{array}{l}\text { Ciências Econômicas, Engenharia de Computação, } \\
\text { Engenharia Automotiva, Engenharia Química, } \\
\text { Administração e Engenharia Ambiental. }\end{array}$ \\
\hline $\begin{array}{l}\text { Engenharia Florestal, Estatística, } \\
\text { Design, Arquitetura e Urbanismo. }\end{array}$ \\
\hline
\end{tabular}




\section{Anexo C Quantidade de vagas ofertadas pelos cursos nos editais de transferência interna $^{10}$}

(Acumulado do período de 1\%/2012 ao 1\%/2016)

\begin{tabular}{|l|c|c|}
\hline \multicolumn{1}{|c|}{ CURSOS DE GRADUAÇÃO* } & $\begin{array}{c}\text { QUANTIDADE DE } \\
\text { INGRESSANTES }\end{array}$ & $\begin{array}{c}\text { QUANTIDADE DE } \\
\text { VAGAS OFERTADAS }\end{array}$ \\
\hline Administração & 46 & 278 \\
\hline Agronomia & 1 & 217 \\
\hline Arquitetura e Urbanismo & 31 & 68 \\
\hline Arquivologia & 14 & 58 \\
\hline Artes Cênicas & 0 & 107 \\
\hline Artes Plásticas & 8 & 197 \\
\hline Biblioteconomia & 2 & 97 \\
\hline Biotecnologia & 4 & 84 \\
\hline Ciência da Computação & 22 & 153 \\
\hline Ciência Política & 28 & 137 \\
\hline Ciências Ambientais & 1 & 185 \\
\hline Ciências Biológicas & 18 & 229 \\
\hline Ciências Contábeis & 16 & 384 \\
\hline Ciências Econômicas & 37 & 162 \\
\hline Ciências Naturais (Planaltina) & 0 & 398 \\
\hline Ciências Sociais & 18 & 413 \\
\hline Computação & 4 & 310 \\
\hline Comunicação Organizacional & 0 & 67 \\
\hline Comunicação Social & 81 & 127 \\
\hline Design & 13 & 35 \\
\hline Direito & 23 & 61 \\
\hline Educação Física & 5 & 212 \\
\hline Enfermagem (Ceilândia) & 11 & 206 \\
\hline Enfermagem (Darcy Ribeiro) & 5 & 133 \\
\hline Engenharia & 0 & 239 \\
\hline Engenharia Aeroespacial (Gama) & 7 & 15 \\
\hline Engenharia Ambiental & 9 & 130 \\
\hline Engenharia Automotiva (Gama) & 2 & 89 \\
\hline Engenharia Civil & 24 & 38 \\
\hline Engenharia de Computação & 59 & 133 \\
\hline Engenharia de Energia (Gama) & 9 & 132 \\
\hline Engenharia de Produção & & 123 \\
\hline Engenharia de Redes de Comunicação & 161 \\
\hline & 5 & \\
\hline
\end{tabular}

\footnotetext{
${ }^{10}$ Nessa tabela os cursos de graduação não foram diferenciados, quando o caso, em turnos. Dessa maneira, Administração - diurno e Administração - noturno, por exemplo, foram considerados como um curso só: Administração.
} 


\begin{tabular}{|c|c|c|}
\hline Engenharia de Software (Gama) & 5 & 89 \\
\hline Engenharia Elétrica & 50 & 69 \\
\hline Engenharia Eletrônica (Gama) & 5 & 99 \\
\hline Engenharia Florestal & 5 & 195 \\
\hline Engenharia Mecânica & 75 & 112 \\
\hline Engenharia Mecatrônica & 10 & 150 \\
\hline Engenharia Química & 16 & 47 \\
\hline Estatística & 11 & 149 \\
\hline Farmácia (Ceilândia) & 6 & 179 \\
\hline Farmácia (Darcy Ribeiro) & 1 & 41 \\
\hline Filosofia & 2 & 429 \\
\hline Física & 8 & 479 \\
\hline Fisioterapia (Ceilândia) & 0 & 145 \\
\hline Fonoaudiologia (Ceilândia) & 0 & 65 \\
\hline Geofísica & 1 & 152 \\
\hline Geografia & 1 & 180 \\
\hline Geologia & 22 & 112 \\
\hline Gestão Ambiental & 2 & 176 \\
\hline Gestão de Agonegócios (Darcy Ribeiro) & 0 & 154 \\
\hline Gestão de Agronegócios (Planaltina) & 0 & 174 \\
\hline Gestão de Políticas Públicas & 9 & 214 \\
\hline Gestão em Saúde Coletiva & 4 & 160 \\
\hline História & 17 & 342 \\
\hline Letras & 23 & 177 \\
\hline Letras - Tradução - Inglês & 13 & 158 \\
\hline Letras-Tradução Espanhol & 3 & 96 \\
\hline Línguas Estrangeiras Aplicadas - MSI & 3 & 176 \\
\hline Matemática & 27 & 450 \\
\hline Medicina & 0 & 0 \\
\hline Medicina Veterinária & 9 & 82 \\
\hline Museologia & 2 & 139 \\
\hline Música & 2 & 99 \\
\hline Nutrição & 16 & 78 \\
\hline Odontologia & 36 & 46 \\
\hline Pedagogia & 7 & 428 \\
\hline Psicologia & 91 & 127 \\
\hline Química & 4 & 377 \\
\hline Química Tecnológica & 1 & 133 \\
\hline Relações Internacionais & 34 & 61 \\
\hline Saúde Coletiva & 0 & 309 \\
\hline Serviço Social & 1 & 210 \\
\hline Teoria Crítica e História da Arte & 2 & 94 \\
\hline Terapia Ocupacional & 0 & 206 \\
\hline Turismo & 1 & 107 \\
\hline
\end{tabular}

